\title{
Chemoenzymatic Synthesis of Organoselenium(IV) Compounds and their Evaluation as Cysteine Protease Inhibitors
}

\author{
Leandro Piovan, ${ }^{a}$ Márcio F. M. Alves, ${ }^{b}$ Luiz Juliano, ${ }^{b}$ Dieter Brömme, ${ }^{c}$ \\ Rodrigo L. O. R. Cunha ${ }^{*, b, d}$ and Leandro H. Andrade ${ }^{*, a}$ \\ anstituto de Química, Universidade de São Paulo, Av. Prof. Lineu Prestes 748, \\ 05508-900 São Paulo-SP, Brazil \\ ${ }^{b}$ Departamento de Biofísica, Escola Paulista de Medicina, Universidade Federal de São Paulo, \\ Rua Três de Maio 100, 04044-200 São Paulo-SP, Brazil \\ 'Department of Dentistry and UBC Center for Blood Research, University of British Columbia, \\ Faculty of Dentistry, Vancouver V6T 1Z3, Canada \\ ${ }^{d}$ Centro de Ciências Naturais e Humanas (CCNH), Universidade Federal do ABC, \\ Av. dos Estados 5001, 09210-580 Santo André-SP, Brazil
}

\begin{abstract}
Uma série de organosselenanas foi sintetizada utilizando-se uma metodologia quimioenzimática. Estas organosselenanas apresentam variações na estereoquímica e no halogênio ligado ao átomo de selênio. Devido à reação característica envolvendo compostos de selênio e tióis, estas organosselenanas foram avaliadas como inibidores de cisteíno proteases (catepsinas $\mathrm{V}$ e S). As constantes de inibição de segunda-ordem mostraram que a catepsina $\mathrm{S}$ é inibida mais rapidamente do que a catepsina V. Pode-se observar que as organosselenanas dibromadas são inibidores mais potentes do que as dicloradas. Desta forma, os resultados obtidos mostram que compostos hipervalentes de selênio podem ser aplicados como inibidores de cisteíno proteases.
\end{abstract}

A series of organoselenium dihalides (organoselenanes) was synthesized from organoselenides using a chemoenzymatic approach. The organoselenanes have variations in their stereochemistry and in the halogen atom bonded to the selenium atom. Because of the unique selenium-thiol chemistry displayed by several organoselenium compounds, the organoselenanes were evaluated as new potential inhibitors of cysteine proteases (cathepsins $\mathrm{S}$ and $\mathrm{V}$ ). By the analysis of the second-order rate constants of the inhibition of cathepsin $\mathrm{S}$ and $\mathrm{V}$, it was possible to conclude that organoselenanes inhibited the cathepsin $\mathrm{S}$ faster than cathepsin V. It was observed higher inhibitory potencies for the dibromo organoselenanes derivatives than the dichloro analogues. In addition, the present data suggest the use of hypervalent selenium compounds as novel motifs for cysteine proteases inhibitors.

Keywords: selenium, cathepsin, inhibitors, biocatalysis

\section{Introduction}

The selenium compounds biological properties have been widely investigated, ${ }^{1}$ especially because selenium is an essential trace element for mammals and organisms. ${ }^{2}$ Selenium was found to compose glutathione peroxidase enzymes (GPx), which are pivotal protective enzymes of cells against oxidizing agents. ${ }^{3}$ The antioxidant activity has been the main studied biological property for organoselenium(II)

*e-mail: rodrigo.cunha@ufabc.edu.br; leandroh@iq.usp.br compounds (organoselenides) 4 $^{4}$ due to the possibility of these selenium-containing compounds act as mimetics of GPx. Because of their antioxidant properties, organoselenides have been studied as antitumor, anti-inflammatory and antiinfective agents, ${ }^{5}$ furthermore, it has been widely reported that selenium acts as chemopreventive agents ${ }^{6}$ and is used as a micronutrient-containing foods. ${ }^{7}$ It was observed that selenium compounds increase the antitumor activity of anticancer drugs and protect against drug-induced toxicity, ${ }^{8}$ induce apoptosis mainly because of their interaction with thiol-dependent enzymes. ${ }^{9}$ This remarkable ability of 
selenium derivatives to inhibit some enzymes relies on their unique selenium-thiol chemistry. ${ }^{10}$ In the case of hypervalent selenium(IV) compounds, the affinity by thiol groups is well known as the reduction of diorganoselenium dichloro to selenides mediated by thiourea, ${ }^{11}$ the reaction of selenoxides with thiols leading to selenides ${ }^{12}$ and the organoselenone moiety displacement by thiols. Biologically, it was demonstrated that organoseleninic acids also inhibit thiol-dependent protein tyrosine phosphatases ${ }^{13}$ due to the particular reactivity of selenium(IV) atom in seleninic acids with thiols, ${ }^{14}$ but there is still a lack on the application of these particular reactivities of hypervalent selenium compounds in biological systems.

Inspired by the sulfur reactivity with selenium compounds, we looked at the cysteine cathepsins, which are lysosomal cysteine proteases, and are often upregulated in various human cancers. They have been implicated in distinct tumorigenic processes, such as angiogenesis, proliferation, and apoptosis and invasion..$^{15}$ The human family of cysteine cathepsins has 11 members (cysteine cathepsin B, C, F, H, K, L, O, S, V, W and X), which share a conserved active site that is formed by cysteine, histidine and asparagine residues. ${ }^{16}$ Based on the structural catalytic proprieties of cysteine proteases and selenium(IV) chemistry, we report our investigation on the creation of a new class of selenium-containing compounds, organoselenanes (selenium(IV) compounds), to be used as novel inhibitors of human cysteine cathepsins $\mathrm{S}$ and $\mathrm{V}$.

\section{Results and Discussion}

In this work, we prepared a small series of seleniumcontaining compounds to be investigated as possible inhibitors of cysteine cathepsins, through which was possible to evaluate the influence of structural elements, such as the chirality and the effect of halogen derivatives (Figure 1).

\section{Synthesis of the achiral organoselenanes 1-2}

The achiral organoselenanes $\mathbf{1 - 2}$ were synthesized from the bromo-benzylic alcohol 7. Initially, this alcohol was transformed into methyl ether $\mathbf{8}$, which was converted into selenide 9 by a bromine/lithium exchange reaction

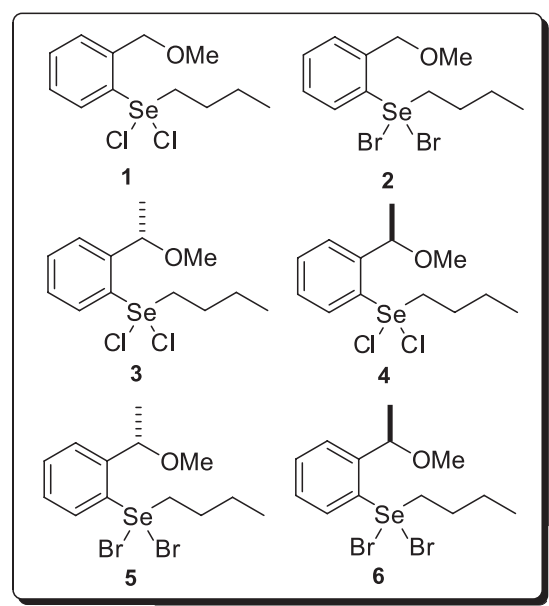

Figure 1. New organoselenanes for inhibition of human cysteine cathepsins.

followed by the capture of the organolithium intermediate with dibutyl diselenide leading to the selenide $\mathbf{9}$ in $70 \%$ yield. When the selenide 9 was reacted with $\mathrm{SO}_{2} \mathrm{Cl}_{2}$ the dichloro organoselenane $\mathbf{1}$ was obtained (> $99 \%$ yield). In the same way, the dibromo organoselenane 2 was prepared from 9 by Se-oxidative reaction with $\mathrm{Br}_{2}$ in high yield (> 99\%; Scheme 1).

\section{Synthesis of the chiral organoselenanes 3-4 and 5-6}

In order to synthesize the chiral organoselenanes 3-4 and 5-6 a chemoenzymatic methodology was developed. Initially, the ketone 11 was synthesized in $45 \%$ yield from 2 '-amino-acetophenone $\mathbf{1 0}$ by using arenediazonium salt and lithium butylselenolate (Scheme 2). Then, reduction of the ketone $\mathbf{1 1}$ afforded the desired chiral seleno-alcohol 12.

Enzymatic kinetic resolution of the alcohol $(R S)-\mathbf{1 2}$ through lipase-catalyzed acetylation was employed to obtain each enantiomer separately. The enzymatic resolution of racemic alcohol $\mathbf{1 2}$ was carried out with vinyl acetate as an acyl donor and CAL-B as biocatalyst (Scheme 3). This reaction was performed in hexane during $\mathbf{2 4} \mathrm{h}$, and the alcohol $(S)-\mathbf{1 2}$ and ester $(R)-\mathbf{1 3}$ were obtained in high enantiomeric excess (up to 99\%).

After enzymatic kinetic resolution, the compounds $(S)$-12 and (R)-13 were purified by flash chromatography and both compounds were obtained in high isolated yield

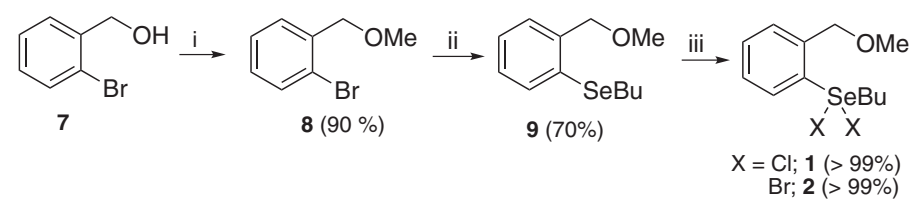

Scheme 1. Reagents and conditions. (i) a: $\mathrm{NaH}, \mathrm{THF}\left(0{ }^{\circ} \mathrm{C}, 30 \mathrm{~min}\right)$; b: $\mathrm{MeI},(\mathrm{rt}, 2 \mathrm{~h})$; (ii) a: $t$-BuLi, THF $\left(-78-0{ }^{\circ} \mathrm{C}, 30 \mathrm{~min}\right)$; b: $\mathrm{BuSeSeBu}, \mathrm{THF}(\mathrm{rt}, 3 \mathrm{~h})$; (iii) $\mathrm{SO}_{2} \mathrm{Cl}_{2}$ or $\mathrm{Br}_{2}, \mathrm{THF}\left(0^{\circ} \mathrm{C}, 15 \mathrm{~min}\right)$. 


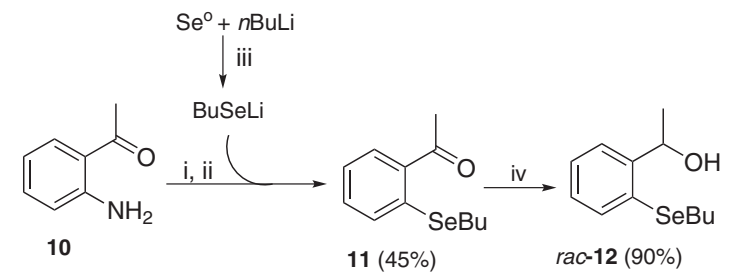

Scheme 2. Reagents and conditions. (i) $\mathrm{NaNO}_{2}, \mathrm{H}_{2} \mathrm{SO}_{4}, \mathrm{H}_{2} \mathrm{O}\left(0-5{ }^{\circ} \mathrm{C}\right)$; (ii) $\mathrm{NaHCO}_{3}$ (pH 7); (iii) $\mathrm{THF}\left(0^{\circ} \mathrm{C}, 1 \mathrm{~h}\right)$; (iv) $\mathrm{NaBH}_{4}, \mathrm{MeOH}$ (rt, 1 h).

(45\%). The alcohol $(R)-\mathbf{1 2}$ was obtained by hydrolysis of the ester $(R)-\mathbf{1 3}$. Thus, by using enzymatic kinetic resolution it was possible to obtain separately both alcohol enantiomers 12 in excellent enantiomeric excess (> 99\%).

The next step, the enantiomerically pure seleno-alcohols $(S)$-12 and $(R)-12$ were transformed into their respective

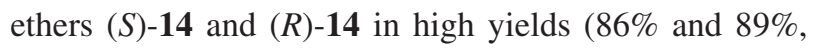

respectively). The organoselenides $(S)$-14 and $(R)$-14 were reacted with $\mathrm{SO}_{2} \mathrm{Cl}_{2}$ and the dichloro organoselenanes $\mathbf{3}$ and 4 were obtained in high yields (> 99\%). In the same way, the dibromo organoselenanes 5 and $\mathbf{6}$ were prepared from $(S)$-14 and $(R)-\mathbf{1 4}$ by Se-oxidative reaction with $\mathrm{Br}_{2}$ in high yield (> 99\%; Scheme 3).

\section{Inhibition of cysteine cathepsins S and Vby organoselenanes}

In order to evaluate the relative potency of the organoselenanes 1-6 as possible inhibitors of cysteine proteases, we selected the cysteine cathepsin $\mathrm{S}$ and $\mathrm{V}$ and a fluorimetric assay to follow the enzymatic activity (Figure 2). The reaction progress was monitored continuously by the fluorescence of the released product (7-amino-4-methylcoumarin, AMC). ${ }^{17,18}$

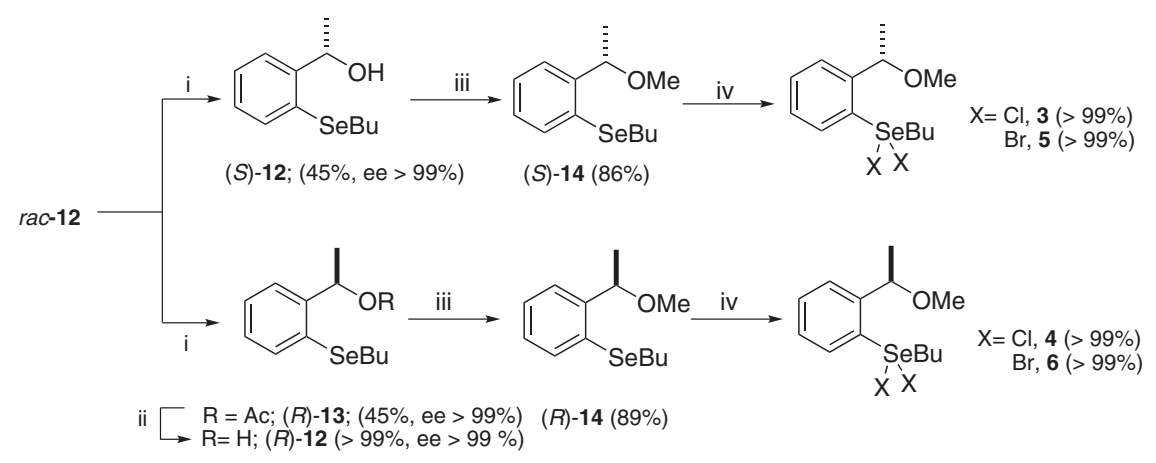

Scheme 3. Reagents and conditions. (i) vinyl acetate, CAL-B, hexane $\left(32{ }^{\circ} \mathrm{C}, 24 \mathrm{~h}\right)$; (ii) $\mathrm{K}_{2} \mathrm{CO}_{3}, \mathrm{MeOH}, \mathrm{H}_{2} \mathrm{O}$ (rt, overnight); (iii) a: $\mathrm{NaH}\left(0{ }^{\circ} \mathrm{C}, 30 \mathrm{~min}\right)$; b: MeI, THF (rt, 2 h); (iv) $\mathrm{SOCl}_{2}$ or $\mathrm{Br}_{2}$, THF $\left(0^{\circ} \mathrm{C}, 15 \mathrm{~min}\right)$.

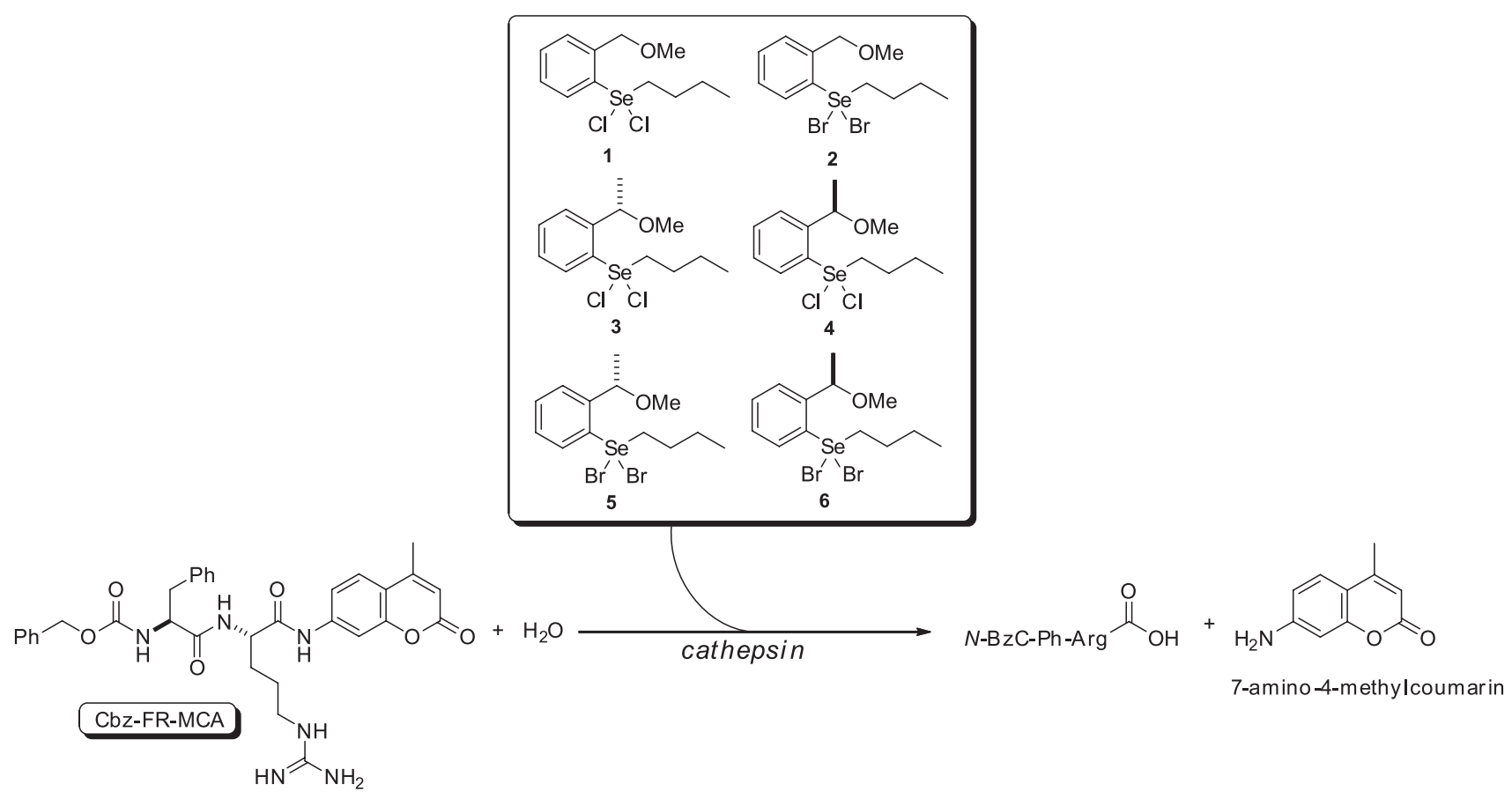

Figure 2. Fluorimetric enzyme assay for new inhibitors of cysteine cathepsin. (7-amino-4-methylcoumarin). 
Fluorimetric enzyme assays were used to evaluate the organoselenanes 1-6 (at $1 \mu \mathrm{mol} \mathrm{L}{ }^{-1}$ ) as cysteine cathepsins inhibitors ( $\mathrm{S}$ and $\mathrm{V}$ ). Initially, the enzyme activities were determined by the hydrolysis of the fluorogenic substrate Cbz-FR-AMC $(1 \mu \mathrm{mol} \mathrm{L}-1)$ in the absence of selenanes (Control assay). Then, each organoselenane 1-6 $\left(1 \mu \mathrm{mol} \mathrm{L}{ }^{-1}\right)$ was pre-incubated with active cathepsin $\mathrm{S}$ (Figure 3) and cathepsin V (Figure 4) for 2 min prior to the addition of the substrate Cbz-FR-AMC. The residual enzyme activities in the presence of each organoselenane were determined and the percentage of inhibition was determined by direct comparison with the control assay.

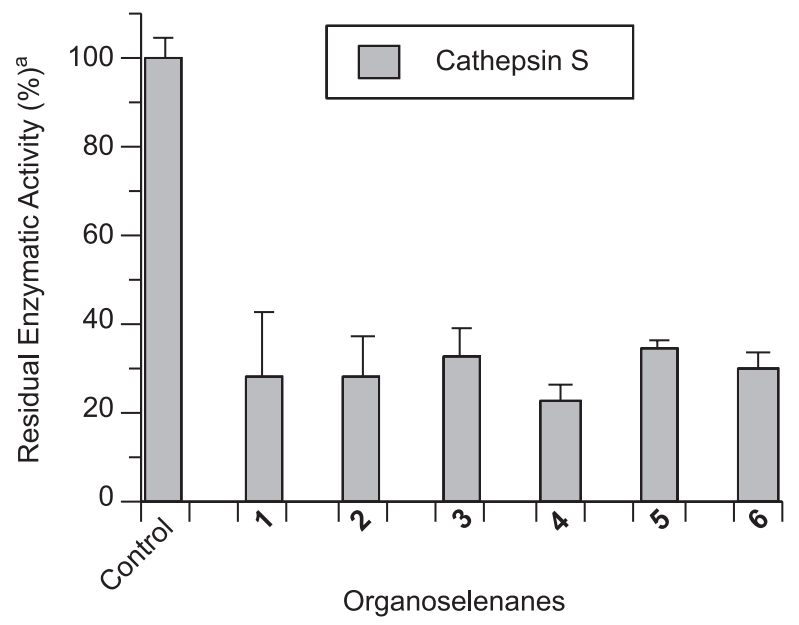

Figure 3. Inhibition profile for cathepsin $S$ using selenanes 1-6 $\left(1 \mu \mathrm{mol} \mathrm{L} \mathrm{L}^{-1}\right)$. Conditions: Cathepsin $\mathrm{S}$ in sodium phosphate buffer $\left(50 \mathrm{mmol} \mathrm{L}^{-1}\right.$; $\left.\mathrm{pH} 6.5\right)$ containing EDTA $\left(2.5 \mathrm{mmol} \mathrm{L}^{-1}\right)$. ${ }^{\mathrm{a}}$ Average of three determinations.

In the assays with the cathepsin S, no significant differences on the percentage of inhibition for dibromo and dichloro organoselenanes was observed. All compounds 1-6 inhibited about $70-80 \%$ of the cathepsin S enzymatic activity, demonstrating that for this enzyme steric factors or different leaving group attached to the selenium atom did not lead to selective interactions. Therefore, the low selectivity showed by this enzyme indicates that all selenanes 1-6 can be equally used as inhibitor without remarkable differentiation. In addition, the possibility of the organoselenides intermediates $\mathbf{9}, \mathbf{1 1}, \mathbf{1 2}$ and $\mathbf{1 4}$ being applied as inhibitor of cathepsins $\mathrm{S}$ and $\mathrm{V}$ was also evaluated. As expected, none of these organoselenides caused any inhibition at the concentration of $1 \mu \mathrm{mol} \mathrm{L}^{-1}$ (For all data, see the Supplementary Information, SI).

On the other hand, assays with the cathepsin V showed that the percentages of inhibition observed for dibromo derivatives $\mathbf{2 , 5}$ and $\mathbf{6}$ were higher than the inhibition observed for dichloro analogues 1, 3 and $\mathbf{4}$ (Figure 4). The achiral dibromo organoselenane $\mathbf{2}$ inhibited $95 \%$ of the activity

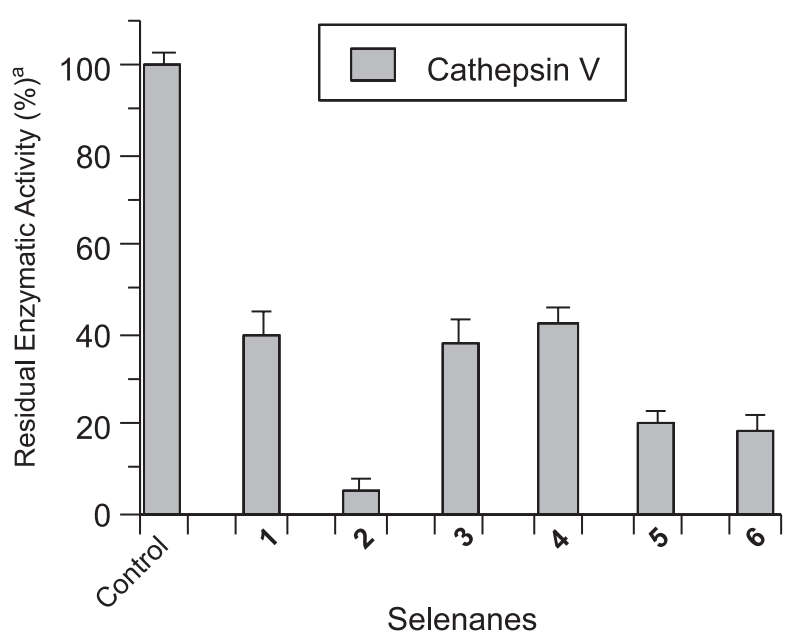

Figure 4. Inhibition profile for cathepsin $\mathrm{V}$ using selenanes 1-6 $\left(1 \mu \mathrm{mol} \mathrm{L}^{-1}\right)$. Conditions: Cathepsin $\mathrm{V}$ in sodium acetate buffer $\left(50 \mathrm{mmol} \mathrm{L}^{-1}\right.$; $\left.\mathrm{pH} 5.5\right)$ containing EDTA $\left(2.5 \mathrm{mmol} \mathrm{L}^{-1}\right) .{ }^{a}$ Average of three determinations.

of this enzyme and the chiral dibromo organoselenanes $\mathbf{5}$ and $\mathbf{6}$ showed $80 \%$ of inhibition. From these results, it was possible to see that the methyl group attached to the benzyl carbon provides a decrease of almost $20 \%$ in the percentage of inhibition of cathepsin $\mathrm{V}$ by the chiral organoselenanes 5 and $\mathbf{6}$ when compared with the organoselenane $\mathbf{2}$, which has no methyl group at that position. However, a discrete difference in the inhibition for the organoselenanes $\mathbf{5}$ and $\mathbf{6}$ showed that the stereochemistry of the benzyl carbon was not relevant and, consequently no enantiomeric preference was observed. Meanwhile, the dichloro organoselenanes 1, 3 and 4 inhibited about $60 \%$ of cathepsin V activity. Surprisingly, the structural differences of $\mathbf{1}, \mathbf{3}$ and $\mathbf{4}$ did not show any significant influence on the inhibition of cathepsin $\mathrm{V}$, as observed for the dibromo compounds. In this case it was possible to notice that cathepsin $\mathrm{V}$ was preferably inhibited by dibromo organoselenanes including the influence of chirality. It is also important to highlight that this qualitative assay showed almost the same inhibitory profile of selenanes 1-6 against cathepsins V and S. However, kinetic constants of the inhibition reaction for each selenane were determined to get a detailed study about inhibitors potency and selectivity.

\section{Inhibition kinetics of cathepsins $S$ and $V$}

The second-order rate constants for inactivation of cathepsins $\mathrm{S}$ and $\mathrm{V}$ by organoselenanes 1-6 were determined $^{17,18}$ as illustrated in Figure 5 to cathepsin V and organoselenane 2. Initially, it was determined the pseudo-first order rate constants $\left(k_{o b s}\right)$ for inactivation of cathepsin $\mathrm{V}$ by different concentrations of selenane $\mathbf{2}$ (Figure 5A). Finally, the second-order rate constants $\left(k_{2}\right)$ were determined by the linear correlation between each 
$k_{\mathrm{obs}}$ and its respective inhibitor concentration, (Figure 5B). The second-order inhibitory constant is obtained from the slope of the curve $k_{\mathrm{obs}}$ versus inhibitor concentration. This method was applied to all compounds against cathepsins V and S (see SI and Table 1).

Organoselenanes showed both time-dependent and concentration-dependent behavior on the inhibition of cathepsins $\mathrm{S}$ and V, as observed in Figure 5A. Dibromo organoselenanes $(\mathbf{2}, \mathbf{5}$ and $\mathbf{6})$ were found to inhibit both enzymes more rapidly (Table 1, entries 2, 5 and 6) than dichloro analogues (1, $\mathbf{3}$ and 4; Table 1, entries 1, 3 and 4). These experimental results can be explained by the nucleophilic substitution of a halogen atom of organoselenanes by the thiol group of cysteine cathepsin, so the best leaving group attached at the selenium atom the highest inhibitory potency was observed. Then, dibromo organoselenanes $\mathbf{2 , 5}$ and $\mathbf{6}$ are much more potent than chlorine organoselenanes 1,3 and 4 .

The presence of the methyl group at the benzylic carbon in the dichloro organoselenanes 3 and $\mathbf{4}$ (Table 1, entries 3 and 4) showed a 2-fold improvement in the second-order inactivation rate constant of the inhibition of cathepsin $\mathrm{V}$ when compared to the achiral analogue 1 (Table1, entry 1), however, for cathepsin $\mathrm{S}$ no difference was observed among these compounds. Notably, a distinct pattern was observed for dibromo organoselenanes (Table 1, entries 2, 5 and 6) in which the presence of methyl group decreased the inhibition rate of cathepsin V. Then, the inhibition of cathepsin $\mathrm{S}$ by the organoselenane 5 (Table 1 , entry 5 ) was 5 -fold faster than its enantiomer $\mathbf{6}$ (Table 1 , entry 6 ).

Gel permeation chromatography assays ${ }^{18,19}$ with cathepsin $\mathrm{V}$ were used to discriminate between reversible and irreversible mechanism for inhibition of cathepsins by organoselenanes. ${ }^{18,20}$ Firstly, cathepsin V was passed

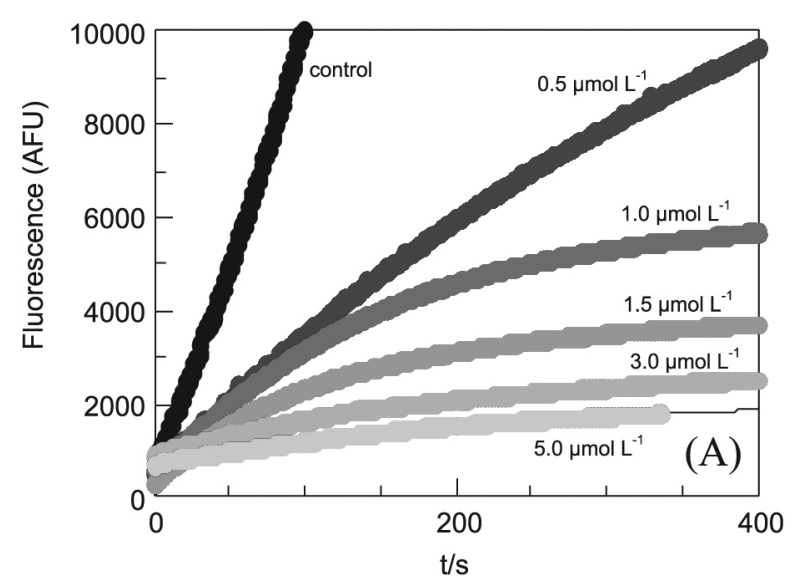

Table 1. Second-order rate constants of the inhibition of cathepsins V and $\mathrm{S}$ by organoselenanes

Cathepsin $\mathrm{V}$ Cathepsin S

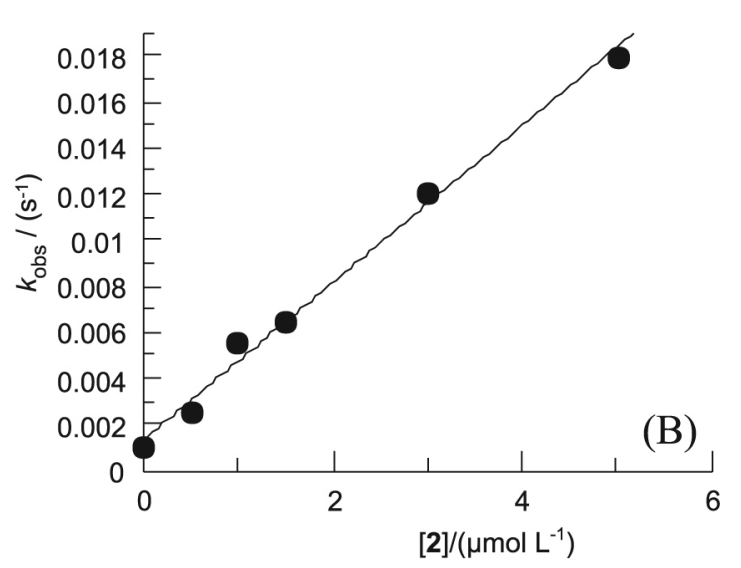

Figure 5. Time course of the inactivation of cathepsin $\mathrm{V}$ with organoselenane 2. (A) The kinetics of inactivation of cathepsin $\mathrm{V}$ was performed in sodium acetate buffer $\left(50 \mathrm{mmol} \mathrm{L}^{-1} ; \mathrm{pH} 5.5\right)$ containing EDTA $\left(2.5 \mathrm{mmol} \mathrm{L}^{-1}\right)$, and different concentration of 2: control, $0.5,1.0,1.5,3.0$ and $5.0 \mu \mathrm{mol} \mathrm{L}{ }^{-1}$ of 2. The reaction progress was monitored continuously by the fluorescence of the released product (methylcoumarin). (B) Cathepsin V first-order rate inactivation in function of organoselenane concentration. 
through the gel permeation chromatography column and around 18 fractions were collected. The enzyme activity was monitored by adding the substrate, Cbz-FR-AMC, to each fraction, which indicated the presence of cathepsin $\mathrm{V}$ in the fractions 6-13 (Figure 6, (O)). Secondly, cathepsin V was incubated with the most active organoselenane 2 followed by submitting the mixture to a gel permeation chromatography, which resulted around 18 fractions. Each fraction was evaluated for cathepsin V activity, however, as observed in the Figure 6 none of the fraction collected from the column showed enzyme activity (Figure 6, ( $\mathbf{(})$ ). The protein content for each fraction was verified by measuring the absorption (Figure 6, (---)). In order to show the presence of inactive cathepsin $\mathrm{V}$ in the fractions with protein content (fractions 8-11), the enzyme activity was recovered by the addition of $5 \mathrm{mmol} \mathrm{L}^{-1}$ of the reducing agent dithiothreitol (DTT), which reduces the sulfur-selenium bond in the inactive enzyme, restoring its functionality (data not shown).

The inhibition of cathepsins by organoselenanes can be based on the reactivity of the selenium(IV) moiety

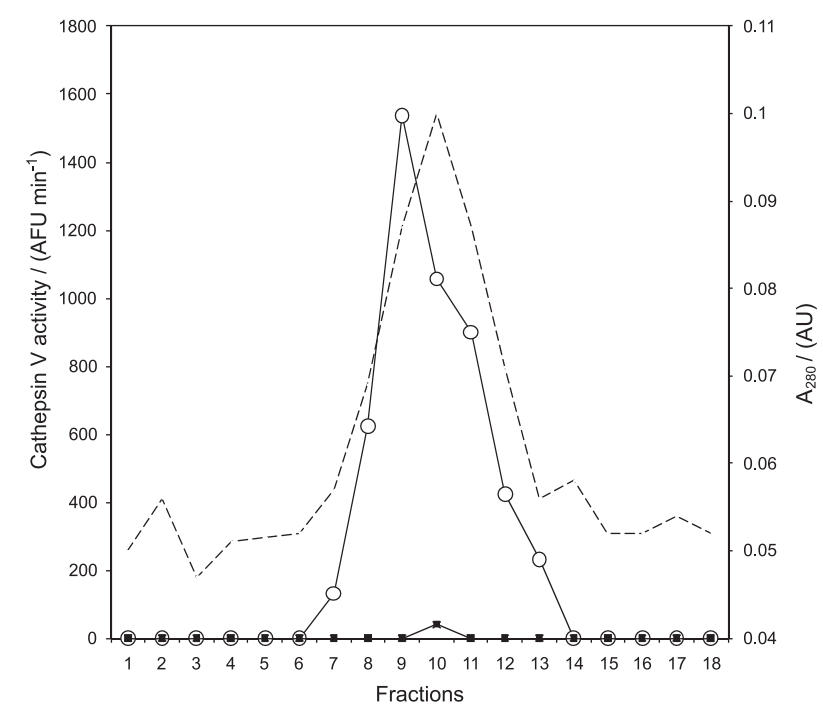

Figure 6. Gel permeation of cathepsin $\mathrm{V}$ with and without selenane 2 . Cathepsin V (432 nmol L-1) was incubated with (ם) and without $(\bigcirc)$ selenane $2\left(60 \mu \mathrm{mol} \mathrm{L}^{-1}\right)$ for $10 \mathrm{~min}$ at $27^{\circ} \mathrm{C}$. $500 \mu \mathrm{L}$ fractions were collected and the cathepsin $\mathrm{V}$ activity for hydrolysis of Cbz-FR-MCA $\left(10 \mu \mathrm{mol} \mathrm{L}^{-1}\right)$ were determined. The protein content was determined by measuring the absorption at $A_{280}$ of each fraction (dotted line). toward the thiol group of these enzymes. A nucleophylic substitution reaction of the sulfur from cysteine cathepsin to the selenium species led to the formation of an S-Se covalent bond, which affords the selenium-cathepsin adduct, resulting in the irreversible inhibition of these enzymes (Figure 7).

\section{${ }^{77}$ Se NMR analysis: evidence of the formation of organoselenane/thiol adduct}

Finally, after the kinetic measurements of the cysteine cathepsins inhibition, another evidence of the interaction of organoselenanes with thiols was accessed by ${ }^{77} \mathrm{Se}$ NMR analysis using cysteine (L-Cys) as a model thiol compound (Figure 8). In a NMR tube, the organoselenane 1 was incubated with increasing ratios of L-Cys $(0,1$ and 2 equiv.) in DMSO- $d_{6}$. The ${ }^{77} \mathrm{Se}$ NMR spectra of the reaction were taken after $1 \mathrm{~h}$ of the addition of 1 equiv. of cysteine (Figure $8 \mathrm{~A}$ ) and $1 \mathrm{~h}$ after the addition of the second equivalent (Figure 8B).

By adding the first equivalent of the cysteine, the original chemical shift of 1 (549 ppm) disappeared and a single new signal at $406 \mathrm{ppm}$ was observed. Two hours after the addition of the second equivalent of cysteine, only the same signal at $406 \mathrm{ppm}$ was observed. These results indicated that the selenium specie that was observed by adding one or two equivalents of cysteine was the same. Therefore, it suggests that there is a substitution of only one atom of chlorine from organoselenane $\mathbf{1}$ by cysteine nucleophilic attack on the selenium atom, indicating that the reaction stoichiometry is $1: 1$. The exchange of one chlorine atom at selenium moiety by one sulfur atom lead to an increase in the electronic density around the selenium atom due to the difference in the electronegativity of the ligands, thus a decrease in the ${ }^{77} \mathrm{Se}$ chemical shift is observed (549 ppm to $406 \mathrm{ppm}$ ).

\section{Experimental}

Unless otherwise noted, commercially available materials were used without further purification. Lipase from Candida antarctica (fraction B, CAL-B) immobilized,

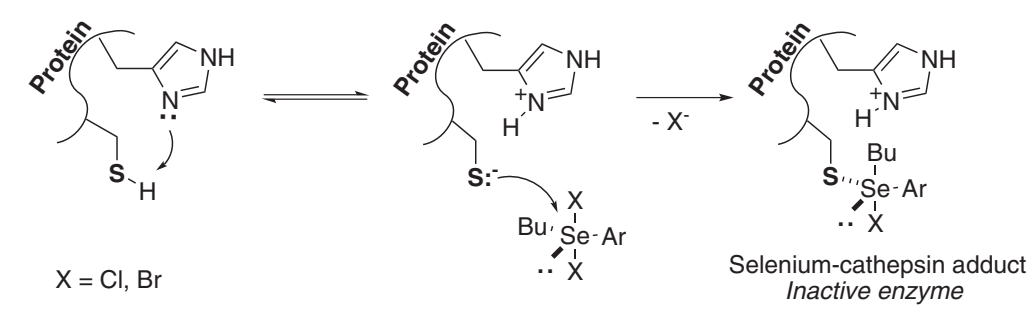

Figure 7. Reasonable mechanism for inhibition of cisteine cathepsins by organoselenanes. 
<smiles>CCCC[Se](Cl)(Cl)c1ccccc1COC</smiles>

$1(\delta=549 \mathrm{ppm})$

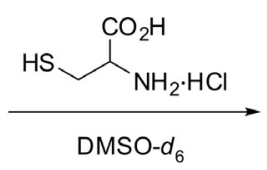

DMSO- $d_{6}$<smiles>CCC</smiles>

$1 \mathbf{a}(\delta=406 \mathrm{ppm})$
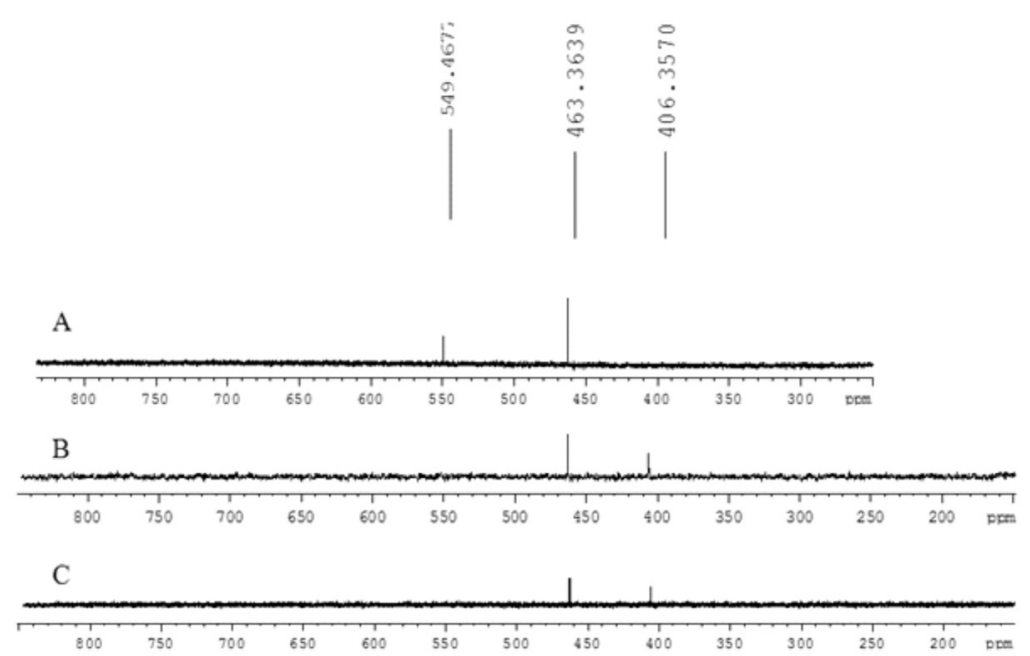

Figure 8. ${ }^{77} \mathrm{Se}$ NMR analysis of organoselenane 1. (A) No addition of cysteine; (B) addition of cysteine 1 equiv. ( $1 \mathrm{~h}$ ); (C) addition of cysteine 2 equiv. (1 h). $(\delta=463$ ppm: internal standard PhSeSePh).

and commercially available as Novozym ${ }^{\circledR} 435$ was kindly donated by Novozymes Latin America Ltda. All solvents were HPLC or ACS grade. Solvents used for moisture sensitive operations were distilled from drying reagents under a nitrogen atmosphere: THF was distilled from $\mathrm{Na} /$ benzophenone.

Analytical thin-layer chromatography (TLC) was performed by using aluminum-backed silica plates coated with a $0.25 \mathrm{~mm}$ thickness of silica gel $60 \mathrm{~F}_{254}$ (Merck), visualized with an ultraviolet light $(\lambda=254 \mathrm{~nm})$, followed by exposure to $p$-anisaldehyde solution, or vanillin solution and heating.

Standard chromatographic purification methods were followed using 35-70 mm (240-400 mesh) silica gel purchased from Acros Organics ${ }^{\circledR}$.

Nuclear magnetic resonance (NMR) spectra were recorded on a Bruker AC 200 or Bruker DRX 300 spectrometer at operating frequencies of 200 and $300 \mathrm{MHz}\left({ }^{1} \mathrm{H} \mathrm{NMR}\right)$ or 50 and $125 \mathrm{MHz}\left({ }^{13} \mathrm{C} \mathrm{NMR}\right)$. The ${ }^{1} \mathrm{H}$ NMR chemical shifts are reported in ppm relative to TMS peak. The data are reported as follows: chemical shift $(\delta)$, multiplicity $(\mathrm{s}=$ singlet, $\mathrm{d}=$ doublet, $\mathrm{t}=$ triplet, $\mathrm{qd}=$ quadruplet, $\mathrm{qt}=$ quintet, $\mathrm{st}=$ sextuplet, $\mathrm{m}=$ multiplet), and coupling constant $(J)$ in Hertz and integrated intensity. The ${ }^{13} \mathrm{C}$ NMR chemical shifts are reported in ppm relative to $\mathrm{CDCl}_{3}$ signal. The ${ }^{77} \mathrm{Se} \mathrm{NMR}$ spectra were obtained on a Bruker DRX 300 spectrometer, using the appropriate decoupling accessories. All ${ }^{77} \mathrm{Se}$ chemical shifts were referenced to internal standard $\mathrm{PhSeSePh}$ (463 ppm).

Infrared spectra were recorded from $\mathrm{KBr}$ discs or from a thin film between $\mathrm{NaCl}$ plates on FTIR spectrometer (Bomem Michelson model 101) with internal reference. Absorption maxima $\left(v_{\max }\right)$ are reported in wavenumbers $\left(\mathrm{cm}^{-1}\right)$.

High-resolution mass spectra (HRMS) were acquired using a Bruker Daltonics MicroTOF instrument, operating electrospray ionization (ESI) mode.

Optical rotations were measured on a Perkin Elmer-343 digital polarimeter in a $1 \mathrm{~mL}$ cuvette with a $1 \mathrm{dm}$ pathlength. All values are reported in the following format: $[\alpha]_{D}($ temperature of measurement $)=$ specific rotation (concentration of the solution reported in units of $10 \mathrm{mg}$ sample per $1 \mathrm{~mL}$ solvent used).

High performance liquid chromatograph (HPLC) analyses for measurement of enantiomeric excesses were performed on a Shimadzu, LC-10AD liquid chromatograph equipped with an autosampler and a variable wavelength UV detector (deuterium lamp 190-600 nm). Chiral columns: Chiralcel ${ }^{\circledR}$ OJ-H $(0.46 \mathrm{~cm} f \times 25 \mathrm{~cm})$ from Daicel Chemical Ind. $i$-PrOH and hexane (60\% $n$-hexane) HPLC grade purchased from J. T. Baker were used as the eluting solvents. 


\section{General procedure for $O$-methylation reactions (8 and 14)}

To a two-necked round-bottomed flask $(25 \mathrm{~mL})$ containing the appropriate alcohol [7, $(S)$-12 or $(R)-\mathbf{1 2}]$ $(1 \mathrm{mmol})$ in dry THF $(10 \mathrm{~mL})$, sodium hydride $(48 \mathrm{mg}$; 2 mmol) was added. This mixture was stirred at $0{ }^{\circ} \mathrm{C}(30 \mathrm{~min})$, then iodomethane $(280 \mathrm{mg} ; 2 \mathrm{mmol})$ was added. The mixture was stirred for $2 \mathrm{~h}$ at room temperature. After that, ammonium chloride satured solution $(10 \mathrm{~mL})$ was added and the organic phase diluted with ethyl acetate $(20 \mathrm{~mL})$. The organic phase was washed with brine $(3 \times 10 \mathrm{~mL})$, separated and dried over anhydrous magnesium sulphate and filtered. The solvent was removed under reduced pressure, and the residue was purified by flash chromatography using a mixture of $n$-hexane and ethyl acetate $(9: 1)$ as eluent to afford the ethers 8, $(S)-14$ and $(R)-\mathbf{1 4}$.

1-Bromo-2-(methoxymethyl)benzene (8): Isolated yield: 90\%; ${ }^{1} \mathrm{H}$ NMR $\left(200 \mathrm{MHz}, \mathrm{CDCl}_{3}\right) \delta: 7.50\left(2 \mathrm{H}, \mathrm{dd}, J_{A}\right.$ $\left.7.90 \mathrm{~Hz} ; J_{B} 7.46 \mathrm{~Hz}\right) ; 7.31(1 \mathrm{H}, \mathrm{m}) ; 7.15(1 \mathrm{H}, \mathrm{t}, J 7.02 \mathrm{~Hz})$; $4.53(2 \mathrm{H}, \mathrm{s}) ; 3.47(3 \mathrm{H}, \mathrm{s}) ;{ }^{13} \mathrm{C} \mathrm{NMR}\left(50 \mathrm{MHz}, \mathrm{CDCl}_{3}\right) \delta$ : $137.7 ; 132.6 ; 129.1 ; 129.0 ; 127.6 ; 122.9 ; 74.1 ; 58.8$. IR (film) $v_{\max } / \mathrm{cm}^{-1}: 3031 ; 2986 ; 2926 ; 2890 ; 2822 ; 1466$; $1443 ; 1380 ; 1106 ; 1207 ; 749$.

Butyl(2-(1-methoxyethyl)phenyl)selane (14): (S)-14: Isolated yield: $86 \%$; Enantiomeric excess $=99 \%$; $[\alpha]_{\mathrm{D}}{ }^{22}=-70.8\left(c=1.06 ; \mathrm{CHCl}_{3}\right) ;(R)-14$ : Isolated yield: 89\%; Enantiomeric excess $=99 \% ;[\alpha]_{\mathrm{D}}^{22}=+70.5(c=1.00$; $\left.\mathrm{CHCl}_{3}\right) ;{ }^{1} \mathrm{H} \mathrm{NMR}\left(200 \mathrm{MHz}, \mathrm{CDCl}_{3}\right) \delta: 7.37$ (2H, d, J 7.46 $\mathrm{Hz}) ; 7.55(2 \mathrm{H}, \mathrm{m}) ; 4.98(1 \mathrm{H}, \mathrm{qd}, J 6.4 \mathrm{~Hz}) ; 4,20(2 \mathrm{H}, \mathrm{qt}, J$ $7.4 \mathrm{~Hz}) ; 3,36(3 \mathrm{H}, \mathrm{s}), 2,32$ (st, 2H, J 7.6 Hz); 1,65 (5H, m); $1,09(3 \mathrm{H}, \mathrm{t}, J 7.5 \mathrm{~Hz}) ;{ }^{13} \mathrm{C} \mathrm{NMR}\left(50 \mathrm{MHz}, \mathrm{CDCl}_{3}\right) \delta: 145.0$; $132.5 ; 130.2 ; 127.9 ; 127.4 ; 126.0 ; 78.2 ; 56.7 ; 32.2 ; 29.9$; $28.0 ; 23.2 ; 13.7 ;{ }^{77} \mathrm{Se} \mathrm{NMR}\left(57.24 \mathrm{MHz}, \mathrm{CDCl}_{3}\right) \delta: 229.8$; IR (film) $v_{\max } / \mathrm{cm}^{-1}: 3054 ; 2973 ; 2959 ; 2929 ; 1589 ; 1572$; $1457 ; 1214 ; 1116 ; 1102 ; 787 ; 701$. HRMS (ESI), [M+Na $]^{+}$: calculated for $\mathrm{C}_{13} \mathrm{H}_{20} \mathrm{NaOSe}=295.0577$. Found 295.0579.

\section{Procedure for the $\mathrm{Br} / \mathrm{Li}$ exchange reaction}

This procedure was done in an oven-dried two-necked round-bottomed flask $(25 \mathrm{~mL})$ containing the 2'-bromobenzylic ether $8(187 \mathrm{mg} ; 1 \mathrm{mmol})$ in dry THF $(10 \mathrm{~mL})$, cooled to $-78{ }^{\circ} \mathrm{C}$ by using dry-ice/acetone bath, tertbutylitium $\left(0.8 \mathrm{~mL}\right.$ of a solution $\left.1.4 \mathrm{~mol} \mathrm{~L}^{-1} ; 1.1 \mathrm{mmol}\right)$ was added dropwise. Afterwards, the mixture was stirred at $0{ }^{\circ} \mathrm{C}$ for $30 \mathrm{~min}$ and dibutyldiselenide ( $301 \mathrm{mg}$; $1.1 \mathrm{mmol}$ ) was added, and the mixture was stirred for $2 \mathrm{~h}$ at room temperature. The reaction was quenched by adding ammonium chloride satured solution $(10 \mathrm{~mL})$, and the organic phase was diluted with ethyl acetate $(20 \mathrm{~mL})$. The organic phase was washed with brine $(3 \times 10 \mathrm{~mL})$, separated and dried over anhydrous magnesium sulphate and filtered. The solvent was removed under reduced pressure and the residue was purified by flash chromatography, using a mixture of $n$-hexane and ethyl acetate (9:1) as eluent to afford $\mathbf{9}$ in $90 \%$ yield.

Butyl(2-(methoxymethyl)phenyl)selane (9): ${ }^{1} \mathrm{H}$ NMR $\left(200 \mathrm{MHz}, \mathrm{CDCl}_{3}\right) \delta: 7.49(1 \mathrm{H}, \mathrm{m}) ; 7.22(1 \mathrm{H}, \mathrm{m}) ; 7.19$ $(2 \mathrm{H}, \mathrm{m}) ; 4.55(2 \mathrm{H}, \mathrm{s}) ; 3.41(3 \mathrm{H}, \mathrm{s}) ; 2.89(2 \mathrm{H}, \mathrm{t}, J 7,0 \mathrm{~Hz})$; $1.71(2 \mathrm{H}, \mathrm{qt}, J 6 \mathrm{~Hz}) ; 1.58(2 \mathrm{H}, \mathrm{st}, J 7.45 \mathrm{~Hz}) ; 0.90(3 \mathrm{H}$, t, $J 7.02 \mathrm{~Hz}) .{ }^{13} \mathrm{C}$ NMR $\left(75 \mathrm{MHz}, \mathrm{CDCl}_{3}\right) \delta: 141.6 ; 136.6$; $128.4 ; 127.9 ; 126.9 ; 116.6 ; 78.0 ; 57.5 ; 33.6 ; 25.1 ; 13.3$; 7.49; ${ }^{77} \mathrm{Se} \mathrm{NMR}\left(57.24 \mathrm{MHz}, \mathrm{CDCl}_{3}\right) \delta: 240.0$; IR (film) $\mathrm{v}_{\max } / \mathrm{cm}^{-1}: 3058 ; 2958 ; 2928 ; 2871 ; 2819 ; 1436 ; 1195 ; 1100$; 748; HRMS (ESI), [M+Na] $]^{+}$: calculated for $\mathrm{C}_{12} \mathrm{H}_{18} \mathrm{NaOSe}$ $=281.0421$; Found 281.0413.

\section{General procedure for the oxidation of selenides (1-6 $)^{21}$}

To an one-necked round-bottomed flask $(25 \mathrm{~mL})$ the appropriate selenide $[\mathbf{8},(S)-\mathbf{1 4}$ or $(R)-\mathbf{1 4}](1 \mathrm{mmol})$ was solubilized in dry THF $(5 \mathrm{~mL})$. The mixture was cooled at $0{ }^{\circ} \mathrm{C}$ and then, a cooled solution of sulfuryl chloride $(1 \mathrm{mmol})$ or bromine $(1 \mathrm{mmol})$ dissolved in THF $(2 \mathrm{~mL})$, was added dropwise. The resulting mixture was stirred at $0{ }^{\circ} \mathrm{C}$ for $20 \mathrm{~min}$ and then the solvent was removed under reduced pressure. The organoselenanes 1-6 were purified by recristallization from a mixture of diethyl ether and hexane in quantitative yields.

1-[Butyl(dichloro)- $\lambda^{4}$-selanyl]-2-(methoxymethyl) benzene (1): ${ }^{1} \mathrm{H}$ NMR $\left(200 \mathrm{MHz}, \mathrm{CDCl}_{3}\right) \delta: 7.82(1 \mathrm{H}, \mathrm{dd}$, $\left.J_{A} 3.6 \mathrm{~Hz}, J_{B} 2.1 \mathrm{~Hz}\right) ; 7.50\left(2 \mathrm{H}, \mathrm{ddd}, J_{\mathrm{A}} 3.9 \mathrm{~Hz}, J_{\mathrm{B}} 3.3 \mathrm{~Hz}\right.$, $\left.J_{\mathrm{C}} 2.4 \mathrm{~Hz}\right) ; 7,4(1 \mathrm{H}, \mathrm{m}) ; 4.92(2 \mathrm{H}, \mathrm{s}) ; 4.14(2 \mathrm{H}, \mathrm{t}, J 8.1 \mathrm{~Hz})$; $3.48(3 \mathrm{H}, \mathrm{s}) ; 2.29(2 \mathrm{H}, \mathrm{qt}, J 7.5 \mathrm{~Hz}) ; 1.66(2 \mathrm{H}, \mathrm{st}, J 7.5$ $\mathrm{Hz}) ; 1.08(3 \mathrm{H}, \mathrm{t}, J 7.2 \mathrm{~Hz}) .{ }^{13} \mathrm{C}$ NMR $\left(50 \mathrm{MHz}, \mathrm{CDCl}_{3}\right) \delta$ : $141.5 ; 137.4 ; 131.4 ; 128.8 ; 126.9 ; 126.5 ; 73.7 ; 60.9 ; 58.7$; 25.8; 22.6. ${ }^{77} \mathrm{Se} \mathrm{NMR}\left(57.24 \mathrm{MHz}, \mathrm{CDCl}_{3}\right) \delta$ : 549.4; IR (KBr) $v_{\max } / \mathrm{cm}^{-1}: 3437 ; 2956 ; 2927 ; 2813 ; 1461 ; 1445$; 1212; 1199; 1106; 1096. Elemental analysis: Calculated for $\mathrm{C}_{12} \mathrm{H}_{18} \mathrm{Cl}_{2} \mathrm{OSe}$ : $\mathrm{C} 49.92 ; \mathrm{H} 5.53 ; \mathrm{Cl} 21.61 \%$. Found: $\mathrm{C} 49.01 ; \mathrm{H} 5.23$; $\mathrm{Cl} 21.43 \%$.

1-[Dibromo(butyl)- $\lambda^{4}$-selanyl]-2-(methoxymethyl) benzene (2): ${ }^{1} \mathrm{H} \mathrm{NMR}\left(300 \mathrm{MHz}, \mathrm{CDCl}_{3}\right) \delta: 7.78(1 \mathrm{H}, \mathrm{m})$; $7.50(2 \mathrm{H} \mathrm{m}) ; 7.38(1 \mathrm{H}, \mathrm{m}) ; 4.87(2 \mathrm{H}, \mathrm{s}) ; 4.08(2 \mathrm{H}, \mathrm{t}, J 8.1$ $\mathrm{Hz}) ; 3.49$ (3H, s); 2.26 (2H, qt, J $6 \mathrm{~Hz}) ; 1.66$ (2H, st, J 7.5 $\mathrm{Hz}) ; 1.09(3 \mathrm{H}, \mathrm{t}, J 7.2 \mathrm{~Hz}) .{ }^{13} \mathrm{C} \mathrm{NMR}\left(75 \mathrm{MHz}, \mathrm{CDCl}_{3}\right) \delta$ : $138.3 ; 137.7 ; 131.5 ; 130.0 ; 129.9 ; 129.3 ; 127.7 ; 73.8$; $58.8 ; 25.8 ; 22.7 ; 16.7 .{ }^{77} \mathrm{Se} \mathrm{NMR}\left(57.24 \mathrm{MHz}, \mathrm{CDCl}_{3}\right) \delta$ : 
483.6; IR (KBr) $v_{\text {max }} / \mathrm{cm}^{-1}: 3437 ; 2992 ; 2959 ; 2924 ; 2822$; 1454; 1442; 1080; 749. Elemental analysis: Calculated for $\mathrm{C}_{12} \mathrm{H}_{18} \mathrm{Br}_{2} \mathrm{OSe}$ : $\mathrm{C} 34.56 ; \mathrm{H} 4.35 ; \mathrm{Br} 38.32 \%$. Found: $\mathrm{C}$ 34.36; $\mathrm{H} 4.37$; $\mathrm{Br} 34.49 \%$.

1-[Butyl(dichloro)- $\lambda^{4}$-selanyl]-2-[1-methoxyethyl] benzene (3 and 4): (S)-3: Isolated yield: $99 \%$; Enantiomeric excess $=>99 \% ;[\alpha]_{\mathrm{D}}^{22}=-66.0\left(c=1.02 ; \mathrm{CHCl}_{3}\right) ;(R)-\mathbf{4}$ : Isolated yield: $99 \%$; Enantiomeric excess $=>99 \%$; $[\alpha]_{\mathrm{D}}{ }^{22}=+66.2\left(c=1.10 ; \mathrm{CHCl}_{3}\right) ;{ }^{1} \mathrm{H} \mathrm{NMR}(200 \mathrm{MHz}$, $\left.\mathrm{CDCl}_{3}\right) \delta: 7.74(1 \mathrm{H}, \mathrm{d}, J 7.9 \mathrm{~Hz}) ; 7.55(3 \mathrm{H}, \mathrm{m}) ; 4.98(1 \mathrm{H}$, qd, $J 6.4 \mathrm{~Hz}) ; 4.20(2 \mathrm{H}, \mathrm{qt}, J 7.4 \mathrm{~Hz}) ; 3.36(3 \mathrm{H}, \mathrm{s}), 2.32$ (st, $2 \mathrm{H}, J 7.6 \mathrm{~Hz}) ; 1.65(5 \mathrm{H}, \mathrm{m}) ; 1.09(3 \mathrm{H}, \mathrm{t}, J 7.5 \mathrm{~Hz}) ;{ }^{13} \mathrm{C} \mathrm{NMR}$ $\left(50 \mathrm{MHz}, \mathrm{CDCl}_{3}\right) \delta: 142.6 ; 141.2 ; 132.3 ; 129.5 ; 128.2$; $125.6 ; 76.9 ; 62.4 ; 57.2 ; 26.0 ; 22.7$ (2C); 13.8. ${ }^{77} \mathrm{Se}$ NMR $\left.\left(57.24 \mathrm{MHz}, \mathrm{CDCl}_{3}\right) \delta: 508.1 ; \mathrm{IR}(\mathrm{KBr})\right) \mathrm{v}_{\max } / \mathrm{cm}^{-1}$ : 3447 ; 2984; 2973; 2961; 2866; 1465; 1442; 1370; 1208; $1110 ; 1052 ; 756$. Elemental analysis: Calculated for $\mathrm{C}_{13} \mathrm{H}_{20} \mathrm{Cl}_{2} \mathrm{OSe}$ : C $45.63 ; \mathrm{H} 5.89 ; \mathrm{Cl} 20.72 \%$. Found: C 45.53; $\mathrm{H} 5.83 ; \mathrm{Cl}, 20.73 \%$.

1-[Dibromo(butyl)- $\lambda^{4}$-selanyl]-2-[1-methoxyethyl) benzene (5 and 6): (S)-5: Isolated yield: $99 \%$; Enantiomeric excess $=>99 \% ;[\alpha]_{\mathrm{D}}^{22}=-80.0\left(c=1.00 ; \mathrm{CHCl}_{3}\right) ;(R)-\mathbf{6}$ : Isolated yield: $99 \%$; Enantiomeric excess $=>99 \%$; $[\alpha]_{\mathrm{D}}{ }^{22}=+79.8\left(c=1.00 ; \mathrm{CHCl}_{3}\right) ;{ }^{1} \mathrm{H} \mathrm{NMR}(200 \mathrm{MHz}$, $\left.\mathrm{CDCl}_{3}\right) \delta: 7.88(1 \mathrm{H}, \mathrm{d}, J 7,9 \mathrm{~Hz}) ; 7.49(2 \mathrm{H}, \mathrm{m}) ; 7.36(1 \mathrm{H}$, m); $4.98(1 \mathrm{H}, \mathrm{qd}, J 6.58 \mathrm{~Hz}) ; 3.71(2 \mathrm{H}, \mathrm{qt}, J 7.02 \mathrm{~Hz})$; $3.54(3 \mathrm{H}, \mathrm{s}) ; 2.22(2 \mathrm{H}, \mathrm{qt}, J 7.46 \mathrm{~Hz}) ; 1.62(5 \mathrm{H}, \mathrm{m}) ; 1.07$ $(3 \mathrm{H}, \mathrm{t}, J 7.5 \mathrm{~Hz}) .{ }^{13} \mathrm{C}$ NMR $\left(50 \mathrm{MHz}, \mathrm{CDCl}_{3}\right) \delta: 143.5$; $131.8 ; 131.5 ; 129.8 ; 129.2 ; 127.8 ; 78.7 ; 56.5 ; 45.9 ; 26.8$; $24.7 ; 20.1 ; 13.8$. IR (KBr) $v_{\max } / \mathrm{cm}^{-1}: 3442 ; 2976 ; 2957$; 2928; 2870; 2824; 1462; 1441; 1105. Elemental analysis: Calculated for $\mathrm{C}_{13} \mathrm{H}_{20} \mathrm{Br}_{2} \mathrm{OSe}: \mathrm{C} 36.22 ; \mathrm{H} 4.68 ; \mathrm{Br} 37.07 \%$. Found: C 36.3 ; $\mathrm{H} 4.65 ; \mathrm{Br} 36.97 \%$.

General procedure for the arenediazonium salt reaction with lithium organoselenolate

The 2'-amino-acetophenone $\mathbf{1 0}$ (405 mg; 3 mmol), sulfuric acid $(0.8 \mathrm{~mL})$ and water $(0.8 \mathrm{~mL})$ were mixed in a $25 \mathrm{~mL}$ round-bottomed flask. The solution was cooled to $0{ }^{\circ} \mathrm{C}$ and an aqueous solution of sodium nitrite (276 mg, $4 \mathrm{mmol}$ in $1 \mathrm{~mL}$ of water) was added dropwise with vigorous stirring. The mixture was stirred for $5 \mathrm{~min}$ and aqueous solution of sodium bicarbonate was added slowly until $\mathrm{pH} 7$. This solution was then transferred to another $50 \mathrm{~mL}$ flask containing a solution of lithium butylselenolate $(1 \mathrm{mmol})$ in THF $(3 \mathrm{~mL})$. The biphasic solution was continuously stirred at room temperature until the gas evolution had ceased. Afterwards, the mixture was diluted with brine $(20 \mathrm{~mL})$ and extracted with ethyl acetate $(2 \times 20 \mathrm{~mL})$. The organic phase was separated and dried over anhydrous magnesium sulphate and filtered. The solvent was removed under reduced pressure and the residue was purified by flash chromatography using a mixture of $n$-hexane and ethyl acetate (9:1) as eluent to afford $\mathbf{1 1}$ in $45 \%$ yield.

1-(2-(Butylselanyl)phenyl)ethanone (11): Isolated yield: 45\%; ${ }^{1} \mathrm{H}$ NMR $\left(200 \mathrm{MHz}, \mathrm{CDCl}_{3}\right) \delta: 7.90(\mathrm{~d}, 1 \mathrm{H}$, $J 7.9 \mathrm{~Hz}) ; 7.44$ (m, 2H); 7.23 (m, 1H); 2.84 (t, 2H, J 7.5 $\mathrm{Hz}) ; 2.63$ (s, 3H); 1.72 (qt, 2H, J 6.9 Hz), 1.50 (st, $3 \mathrm{H}$, $J 7.3 \mathrm{~Hz}$ ); 0.95 (t, $3 \mathrm{H}, J 7.2 \mathrm{~Hz}) ;{ }^{13} \mathrm{C}$ NMR $(50 \mathrm{MHz}$, $\left.\mathrm{CDCl}_{3}\right) \delta: 98.9 ; 138.5 ; 135.5 ; 132.4 ; 131.8 ; 128.4 ; 124.3$; $30.8 ; 27.7 ; 24.8 ; 23.5 ; 13.8$; IR (film) $v_{\text {max }} / \mathrm{cm}^{-1}: 2957,2928$, $1666,1457,1428,1248 ;$ HRMS (ESI), [M+Na $]^{+}$: calculated for $\mathrm{C}_{12} \mathrm{H}_{16} \mathrm{OSeNa}=279.0264$. Found 279.0260.

Enzymatic kinetic resolution of 1-(2-(butylselanyl)phenyl) ethanol (12)

To an one-necked round-bottomed flask (100 mL) containing 1-(2-(butylselanyl)phenyl)ethanol rac-12 $(1.285 \mathrm{~g} ; 5 \mathrm{mmol})$ in hexane $(20 \mathrm{~mL})$, CAL-B (Novozyme $435 ; 400 \mathrm{mg})$ and vinyl acetate $(0.86 \mathrm{~g} ; 15 \mathrm{mmol})$ were added. The mixture was stirred in an orbital shaker at $32{ }^{\circ} \mathrm{C}$ for $24 \mathrm{~h}(160 \mathrm{rpm})$. Following that, the enzyme was filtered off and washed with dichloromethane $(3 \times 20 \mathrm{~mL})$. The solvent was removed under reduced pressure and the residue was purified by flash chromatography using a mixture of $n$-hexane and ethyl acetate (9:1) as eluent to afford $(S)$-12 (ee 99\%) and (R)-13 (ee 99\%) in 45\% yield each one.

(S)-1-(2-(butylselanyl)phenyl)ethanol (12): Isolated yield $=45 \%$; Enantiomeric excess $>99 \% ;[\alpha]_{\mathrm{D}}^{22}=-23,9$ $\left(c=0.78 ; \mathrm{CHCl}_{3}\right) ;{ }^{1} \mathrm{H} \mathrm{NMR}\left(200 \mathrm{MHz}, \mathrm{CDCl}_{3}\right) \delta: 7.50(\mathrm{~m}$, $2 \mathrm{H}) ; 7.23(\mathrm{~m}, 2 \mathrm{H}) ; 5.30$ (qd, 1H, $J 6.3 \mathrm{~Hz}) ; 2.91$ (t, 2H, $J$ $7.5 \mathrm{~Hz}) ; 2,3$ (s, 1H); 1.70 (qt, 2H, J 7.4 Hz); 1.44 (m, 5H); 0.96 (t, $3 \mathrm{H}, J$ 7.24); ${ }^{13} \mathrm{C}$ NMR (50 MHz, $\mathrm{CDCl}_{3}$ ) $\delta: 146.9$; $132.7 ; 129.4 ; 128.0 ; 127.4 ; 125.6 ; 69.3 ; 32.2 ; 28.2 ; 24.3$; 23.2; 13.7; IR (film) $v_{\max } / \mathrm{cm}^{-1}: 3361,3057,2961,2928$, 2870, 1463, 1008, 754; HRMS (ESI), [M+Na] $]^{+}$calculated for $\mathrm{C}_{12} \mathrm{H}_{18} \mathrm{OSeNa}=281.0421$. Found 281.0416.

(R)-1-(2-(butylselanyl)phenyl)ethyl acetate (13): Isolated yield $=45 \%$; Enantiomeric excess $>99 \%$; $[\alpha]_{\mathrm{D}}{ }^{22}=+36.1\left(c=0.80 ; \mathrm{CHCl}_{3}\right) ;{ }^{1} \mathrm{H}$ NMR $(200 \mathrm{MHz}$, $\left.\mathrm{CDCl}_{3}\right) \delta: 7.51(1 \mathrm{H}, \mathrm{dd}, J 1.30 \mathrm{~Hz}) ; 7.41(1 \mathrm{H}, \mathrm{dd}, J 1.70$ $\mathrm{Hz}) ; 7,22(\mathrm{~m}, 2 \mathrm{H}) ; 6.29(\mathrm{qd}, 1 \mathrm{H}, J 6.58 \mathrm{~Hz}) ; 2.91$ (t, 2H, $J$ $7.5 \mathrm{~Hz}) ; 2.92(2 \mathrm{H}, \mathrm{t}, J 7.5 \mathrm{~Hz}) ; 2.08(1 \mathrm{H}, \mathrm{s}) ; 1.70(2 \mathrm{H}, \mathrm{qt}$, 
$J 7.90 \mathrm{~Hz}) ; 1.44$ (m, 5H); 0.92 (3H, t, J 7.02); ${ }^{13} \mathrm{C} \mathrm{NMR}$ $\left(50 \mathrm{MHz}, \mathrm{CDCl}_{3}\right) \delta: 170.2 ; 143.9 ; 136.7 ; 133.8 ; 128.3$; $127.6 ; 125.8 ; 72.1 ; 32.2 ; 28.4 ; 23.1 ; 22.0 ; 21.4 ; 13.7$. IR (film) $v_{\max } / \mathrm{cm}^{-1}: 3058 ; 2959 ; 2930 ; 2870 ; 1735 ; 1466 ; 1370$; $1237 ; 1070,757 \mathrm{~cm}^{-1}$; HRMS (ESI), [M+Na] $]^{+}$: calculated for $\mathrm{C}_{14} \mathrm{H}_{20} \mathrm{OSeNa}=323.0526$. Found 323.0515.

Screening for inhibitory activity of organoselenanes against cathepsins $S$ and $V$

The cathepsins kinetics of Cbz-FR-MCA hydrolysis were performed in the optimal conditions for each enzyme. Cathepsin $\mathrm{S}\left(1.5 \mathrm{nmol} \mathrm{L}^{-1}\right)$ : sodium phosphate buffer $\left(50 \mathrm{mmol} \mathrm{L}^{-1}\right.$; $\left.\mathrm{pH} 6.5\right)$ containing EDTA $\left(2.5 \mathrm{mmol} \mathrm{L}^{-1}\right)$; Cathepsin V $\left(3.2 \mathrm{nmol} \mathrm{L}^{-1}\right)$ : sodium acetate buffer $\left(50 \mathrm{mmol} \mathrm{L}^{-1} ; \mathrm{pH} 5.5\right)$ containing EDTA $\left(2.5 \mathrm{mmol} \mathrm{L}^{-1}\right)$. The screening of the inhibition of cathepsins was performed by the incubation of each cathepsin with the organoselenanes 1-6 $\left(1 \mu \mathrm{mol} \mathrm{L}^{-1}\right)$ for $2 \mathrm{~min}$ in the appropriate buffer solution at $37^{\circ} \mathrm{C}$, then the fluorogenic substrate Cbz-FR-ACM was added and the remaining enzyme activity was determined. The residual cathepsin activities $\left(\mathrm{A}_{2}\right)$ were expressed as a percentage of the activity of from the control experiment ( $\mathrm{A}_{1}$; in the absence of selenanes) by the following ratio:

Residual Enzymatic Activity $(\%)=\left(\mathrm{A}_{2} / \mathrm{A}_{1}\right) \times 100$

\section{Inactivation kinetics}

Cathepsins activities were monitored spectrofluorometrically using the fluorogenic substrate Cbz-FR-AMC on a Hitachi F-2000 spectrofluorometer equipped with a thermostated cell holder. The excitation and emission wavelengths were set at 380 and $460 \mathrm{~nm}$, respectively. The continuous method ${ }^{16}$ was employed and the inhibition of activated cysteine proteases were carried out in the presence of substrate and different concentrations of each organoselenane, as described before. ${ }^{17}$ The substrate concentrations were kept 10-fold below the $\mathrm{K}_{\mathrm{M}}$ values. The kinetics of cathepsin inactivation by organoselenanes were obtained in pseudo-first-order conditions. The inhibition reaction was monitored continuously by the fluorescence of the enzymatic-released Cbz-FR-AMC. The hydrolysis progress curves were obtained in pseudo-first-order conditions and treated by non-linear regression according to equation 1 as reported previously: ${ }^{22}$

$\mathrm{P}=\left(\mathrm{v}_{\mathrm{z}} / k_{\mathrm{obs}}\right)\left[1-\exp \left(-\mathrm{k}_{\mathrm{obs}} \mathrm{t}\right)\right]+\mathrm{d}$

where $\mathrm{P}$ is the product concentration (in our case it is proportional to the fluorescence of AMC) at a given time, $\mathrm{v}_{\mathrm{z}}$ is velocity of substrate hydrolysis for zero time and $k_{\mathrm{obs}}$ is the observed first-order rate of organoselenane-induced enzyme inactivation and $d$ is the basal fluorescence before adding the enzyme.

Determination of inhibition mechanism by gel permeation chromatography

In order to show the irreversible inhibition of cathepsins by organoselenanes, the most potent inhibitor, organoselenane $\mathbf{2}$, was chosen and used as follows.

Gel permeation chromatography of cathepsin V: A $2.5 \mathrm{~mL}$ solution of activated cathepsin $\mathrm{V}$ was loaded on a $1 \times 10-\mathrm{cm}$ Sephadex G-25 column (Amersham PD10 column, Amersham), pre-equilibrated with sodium acetate buffer (50 $\mathrm{mmol} \mathrm{L}^{-1}, \mathrm{pH}$ 5.5) containing EDTA $\left(2.5 \mathrm{mmol} \mathrm{L}^{-1}\right)$ at $27{ }^{\circ} \mathrm{C}$. Around 18 fractions $(500 \mu \mathrm{L}$ fractions) were collected. The enzyme activity was monitored by adding the substrate, Cbz-FR-AMC, to each fraction.

Gel permeation chromatography of cathepsin V and organoselenane 2: A solution of activated cathepsin V was incubated with the most active organoselenane 2 $\left(10 \mathrm{mmol} \mathrm{L}^{-1}\right)$, in a total volume of $2.5 \mathrm{~mL}$, for $10 \mathrm{~min}$. Then, this mixture was loaded on a $1 \times 10-\mathrm{cm}$ Sephadex G-25 column (Amersham PD-10 column, Amersham), pre-equilibrated with sodium acetate buffer $\left(50 \mathrm{mmol} \mathrm{L}^{-1}\right.$, $\mathrm{pH} 5.5)$ containing EDTA $\left(2.5 \mathrm{mmol} \mathrm{L}^{-1}\right)$ at $27^{\circ} \mathrm{C}$. Around 18 fractions (500 $\mu \mathrm{L}$ fractions) were collected. The enzyme activity was monitored by adding the substrate, Cbz-FR-AMC, to each fraction. The protein content for each fraction was verified by measuring the absorption $\mathrm{A}_{280^{\circ}}$.

\section{Conclusions}

We have synthesized a series of hypervalent organoselenium compounds (organoselenanes), and it has been demonstrated, for the first time, that these compounds can be efficiently used as cysteine protease inhibitors. The inhibition of these enzymes is irreversible and showed a time-dependent and concentrationdependent behavior. In addition, the enzyme activity was totally restored after the treatment of the seleniumcathepsin adduct (inactive enzyme) with the reducing agent dithiothreitol (DTT). We expect that the present report will provide a good basis for the development of novel cysteine protease inhibitors based on selenium(IV) compounds. 


\section{Supplementary Information}

Supplementary information, with characterization data $\left({ }^{1} \mathrm{H},{ }^{13} \mathrm{C}\right.$ and ${ }^{77} \mathrm{Se} \mathrm{NMR}, \mathrm{IR}$ and mass spectrometry) for all compounds and enantiomeric separation for chiral selenium compounds by chiral HPLC, are available, free of charge, at http://jbcs.sbq.org.br, as PDF file.

\section{Acknowledgments}

We thank CNPq, CAPES and FAPESP for financial support.

\section{References}

1. Nogueira, C. W.; Zeni, G.; Rocha, J. B.T.; Chem. Rev. 2004, 104, 6255; Mugesh, G.; du Mont, W-W.; Sies, H.; Chem. Rev. 2001, 101, 2125.

2. Schwarz, K.; Foltz, C. M.; J. Am. Chem. Soc. 1957, 79, 3292.

3. Rotruck, J. T.; Ganther, H. E.; Swanson, A. B.; Hafeman, D. G.; Hoekstra, W. G.; Science 1973, 179, 588; Mai, J.; Sorensen, P. S.; Hansen, J. C.; Biol. Trace Elem. Res. 1990, 24, 109.

4. Battin, E. E.; Brumaghim, J. L.; Cell Biochem. Biophys. 2009, 55, 1; Bhabak, K. P.; Mugesh, G.; Chem. Asian J. 2009, 4, 974; Schewe, T.; Gen. Pharmacol. 1995, 26, 1153.

5. Sanmartin, C.; Plano, D.; Palop, J. A.; Mini-Rev. Med. Chem. 2008, 8, 1020; Duntas, L. H.; Horm. Metab. Res. 2009, 41, 443 ; Rikiishi, H.; J. Bioenerg. Biomembr. 2007, 39, 91; Fleming, J.; Ghose, A.; Harrison, P. R.; Nutr. Cancer 2001, 40, 42.

6. Combs Jr., J. F.; Gray, W. P.; Pharmacol. Ther. 1998, 79, 179.

7. El-Bayoumy, K.; Can. Res. 1985, 45, 3631; Schrauzer, G. N.; Crit. Rev. Biotechnol. 2009, 29, 10.

8. Cao, S.; Durrani, F. A.; Rustum, Y. M.; Clinical Cancer Res. 2004, 10, 2561.

9. Zhou, N.; Xiao, H.; Li, T-K.; Nur-E-Kamal; A.; Liu, L. F.; J. Biol. Chem. 2003, 278, 29532; Sinha, R.; El-Bayoumy, K.; Curr. Cancer Drug Targets 2004, 4, 13.
10. Ganther, H. E.; Carcinogenesis 1999, 20, 1657.

11. Engman, L.; Tetrahedron Lett. 1985, 26, 638.

12. Bhabak, K. P.; Mugesh, G.; Inorg. Chem. 2009, 48, 2449.

13. Abdo, M.; Liu, S.; Zhou, B.; Walls, C. D.; Wu, L.; Knapp, S.; Zhang, Z. Y.; J. Am. Chem. Soc. 2008, 130, 13196.

14. Krief, A.; Dumont, W.; Denis, J.; J. Chem. Soc., Chem. Commun. 1985, 571; Tiecco, M.; Chianelli, D.; Testaferri, L.; Tingoli, M.; Bartoli, D.; Tetrahedron 1986, 42, 4889; Tiecco, M.; Testaferri, L.; Bagnolli, L.; Scarponi, C.; Temperini, A.; Marini, F.; Santi, C.; Tetrahedron: Asymm. 2007, 18, 2758.

15. Joyce, J. A.; Gocheva, V.; Cell Cycle 2007, 6, 60; Brömme, D.; Kaleta, J.; Curr. Pharm. Design 2002, 8, 1639.

16. Joyce, J. A.; Palermo, C.; Trends Pharmacol. Sci. 2007, $29,22$.

17. Brubacher, L. J.; Glick, B. R.; Biochemistry 1979, 13, 915; Johnson, L. A.; Moon, K. E.; Eisenberg, M.; Biochim. Biophys. Acta 1988, 953, 269.

18. Cunha, R. L. O. R.; Urano, M. E.; Chagas, J. R.; Almeida, P. C.; Bincoletto, C.; Tersariol, I. L. S.; Comasseto, J. V.; Bioorg. Med. Chem. Lett. 2005, 15, 755; Persike, D. S.; Cunha, R. L. O. R.; Juliano, L.; Silva, I. R. ; Rosim, F. E.; Vignoli, T.; Dona, F.; Cavalheiro, E.A.; Fernandes, M. J.; Neurobiol. Dis. 2008, 31, 120; Cunha, R. L. O. R.; Gouvea, I. E.; Feitosa, G. P. V.; Alves, M. F. M.; Brömme, D.; Comasseto, J. V.; Tersariol, I. L. S.; Juliano, L.; Biol. Chem. 2009, 390, 2305.

19. Silverman, R. B.; Methods Enzymol. 1995, 249, 240.

20. Silverman, R. B.; Methods Enzymol. 1995, 249, 240.

21. Procedure adapted from: Engman, L.; Organometallics 1984, 3, 1308.

22. Baici, A.; Schenker, P.; Wachter, M.; Ruedi, P.; Chem. Biodiversity 2009, 6, 261.

Submitted: March 12, 2010

Published online: July 20, 2010

FAPESP has sponsored the publication of this article. 


\title{
Chemoenzymatic Synthesis of Organoselenium(IV) Compounds and their Evaluation as Cysteine Protease Inhibitors
}

\author{
Leandro Piovan, ${ }^{a}$ Márcio F. M. Alves, ${ }^{b}$ Luiz Juliano, ${ }^{b}$ Dieter Brömme, ${ }^{c}$ \\ Rodrigo L. O. R. Cunha ${ }^{*, b, d}$ and Leandro H. Andrade ${ }^{*, a}$ \\ a Instituto de Química, Universidade de São Paulo, Av. Prof. Lineu Prestes 748, \\ 05508-900 São Paulo-SP, Brazil
}

${ }^{b}$ Departamento de Biofísica, Escola Paulista de Medicina, Universidade Federal de São Paulo, Rua Três de Maio 100, 04044-200 São Paulo-SP, Brazil

${ }^{c}$ Department of Dentistry and UBC Center for Blood Research, University of British Columbia, Faculty of Dentistry, Vancouver V6T 1Z3, Canada

${ }^{d}$ Centro de Ciências Naturais e Humanas (CCNH), Universidade Federal do ABC, Av. dos Estados 5001, 09210-580 Santo André-SP, Brazil

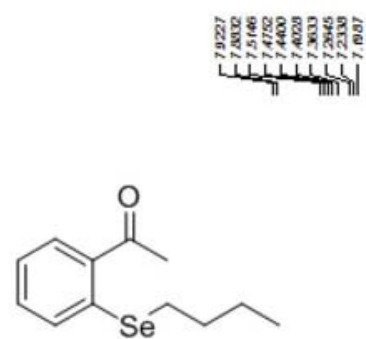

11

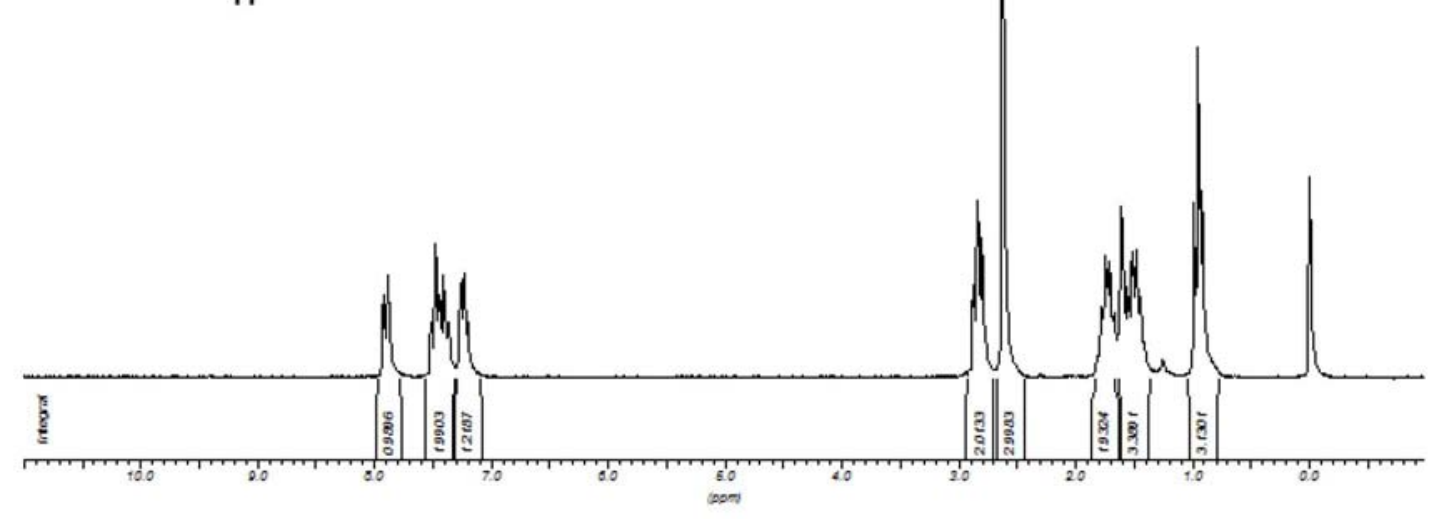

Figure S1. ${ }^{1} \mathrm{H}$ NMR (200 MHz, $\mathrm{CDCl}_{3}$ ) spectrum of 1-(2-(butylselanyl)phenyl)ethanone (11). 

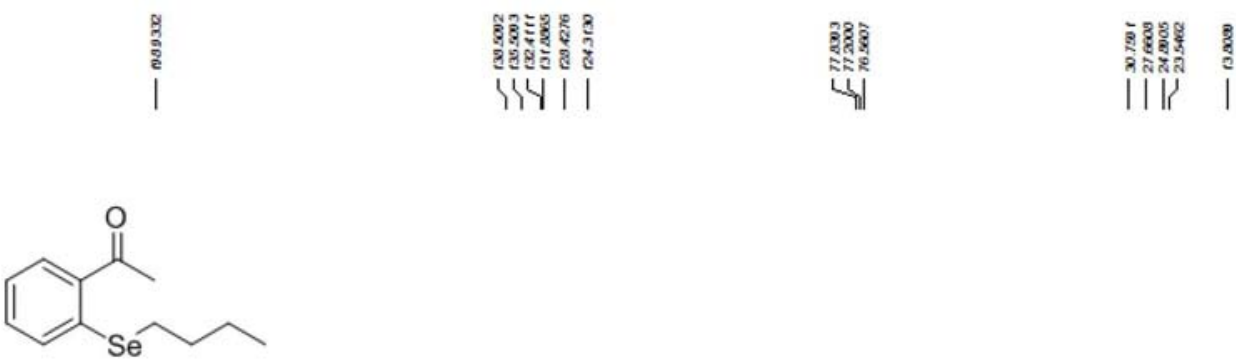

11
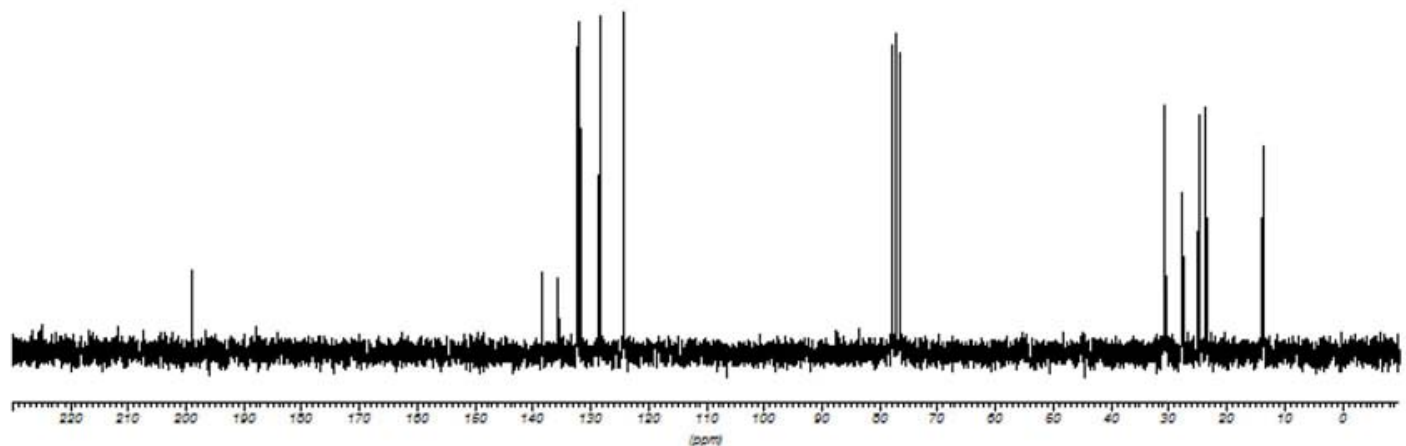

Figure S2. ${ }^{13} \mathrm{C}$ NMR (50 MHz, $\mathrm{CDCl}_{3}$ ) spectrum of 1-(2-(butylselanyl)phenyl)ethanone (11).

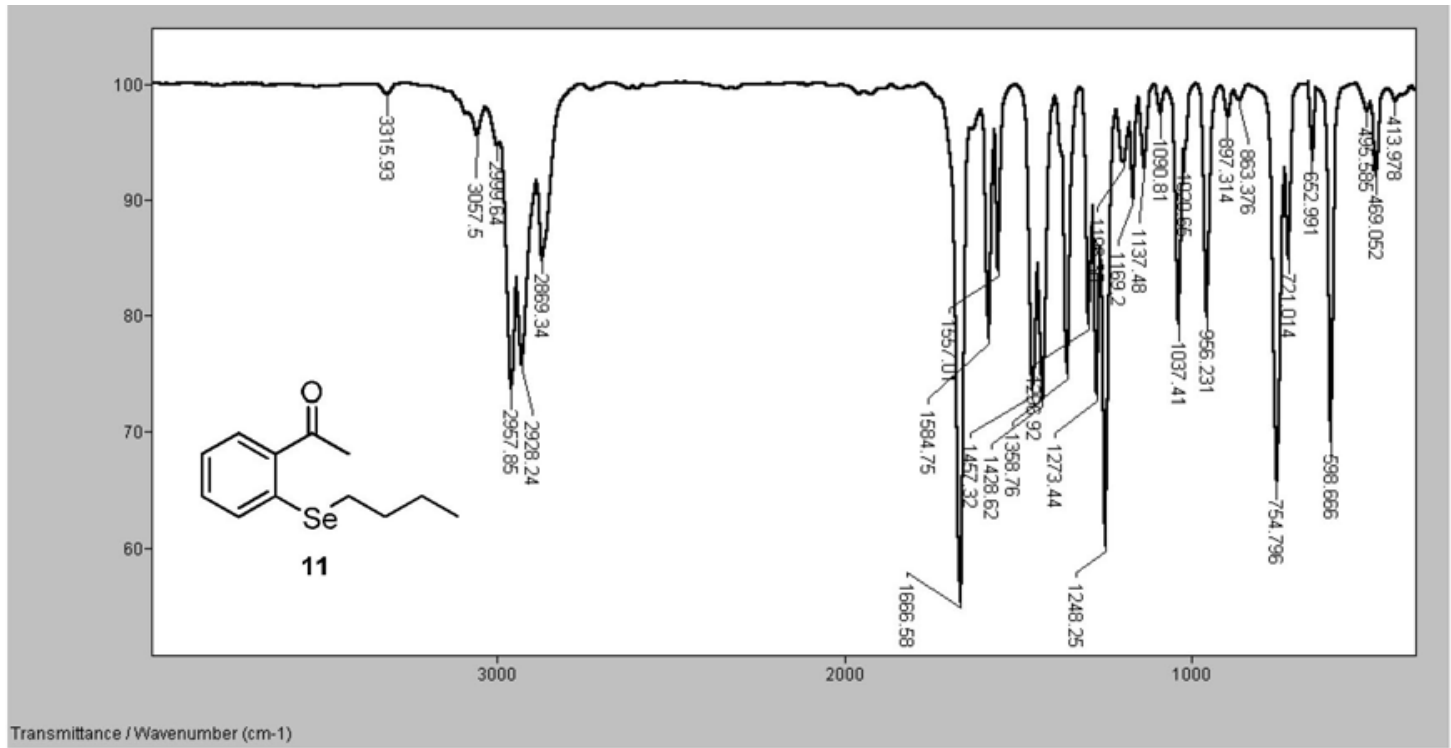

Figure S3. Infrared spectrum of 1-(2-(butylselanyl)phenyl)ethanone (11). 


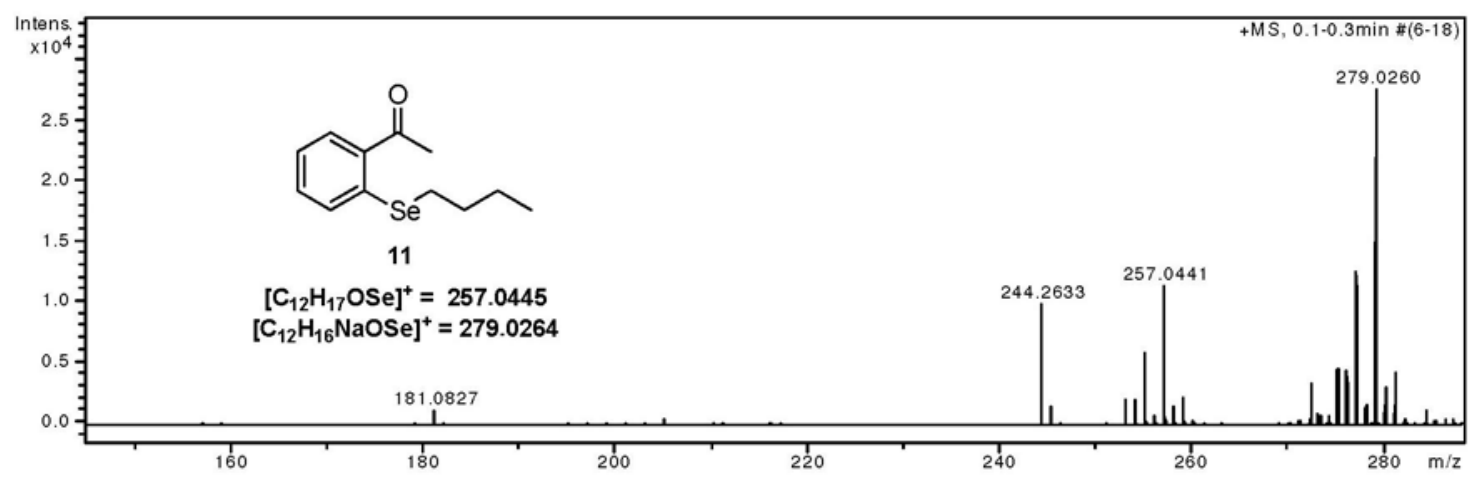

Figure S4. High resolution mass spectrum (ESI) of 1-(2-(butylselanyl)phenyl)ethanone (11).

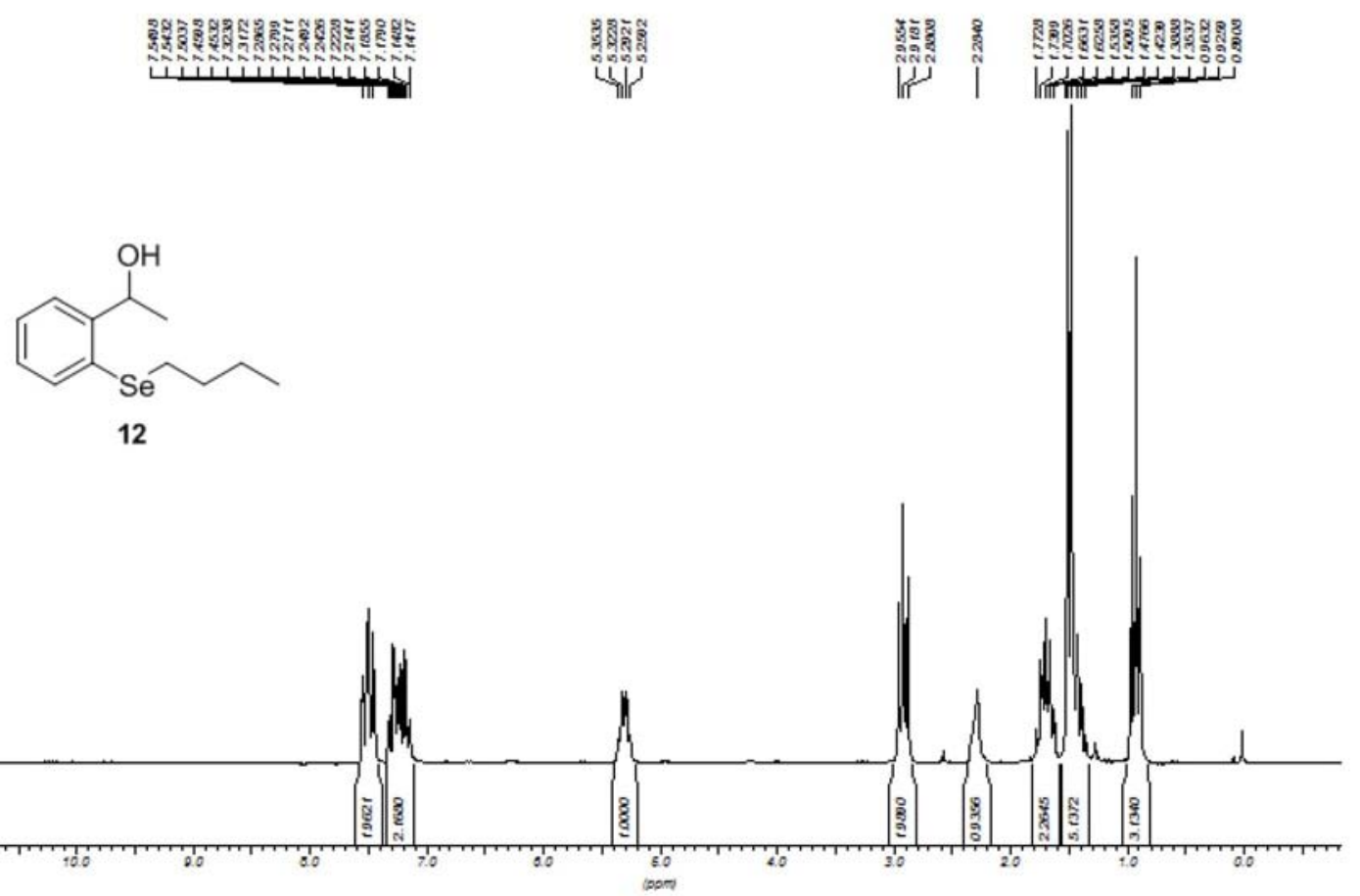

Figure S5. ${ }^{1} \mathrm{H}$ NMR (200 MHz, $\mathrm{CDCl}_{3}$ ) spectrum of 1-(2-(butylselanyl)phenyl)ethanol (12). 
<smiles>CCCC[Se]c1ccccc1C(C)O</smiles>

12

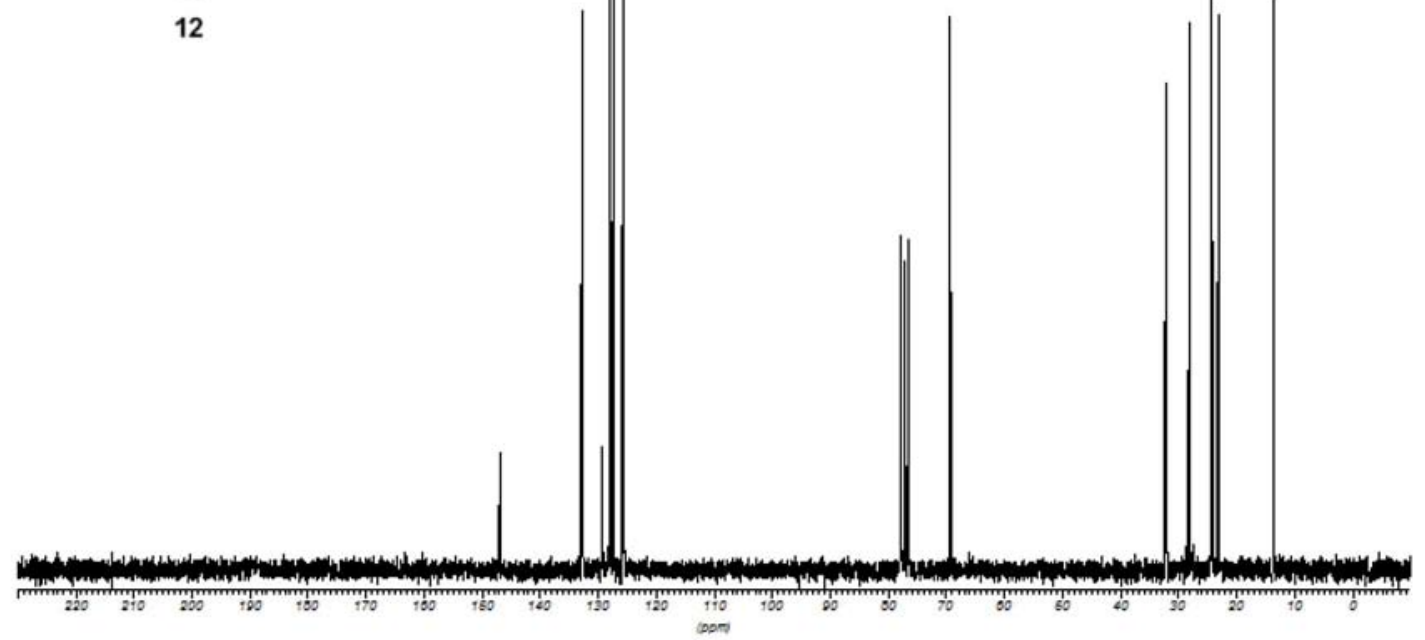

Figure S6. ${ }^{13} \mathrm{C}$ NMR (50 MHz, CDCl3) spectrum of 1-(2-(butylselanyl)phenyl)ethanol (12).

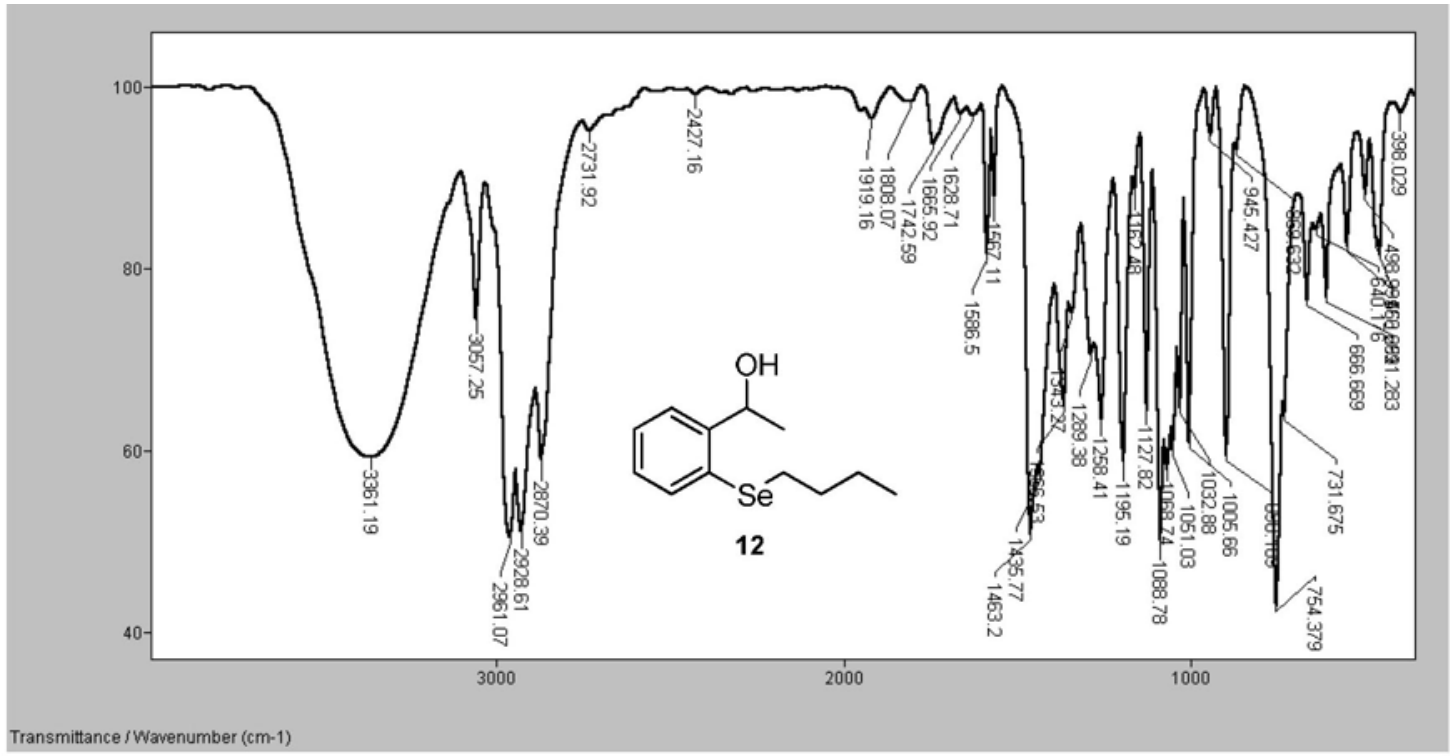

Figure S7. Infrared spectrum of 1-(2-(butylselanyl)phenyl)ethanol (12). 


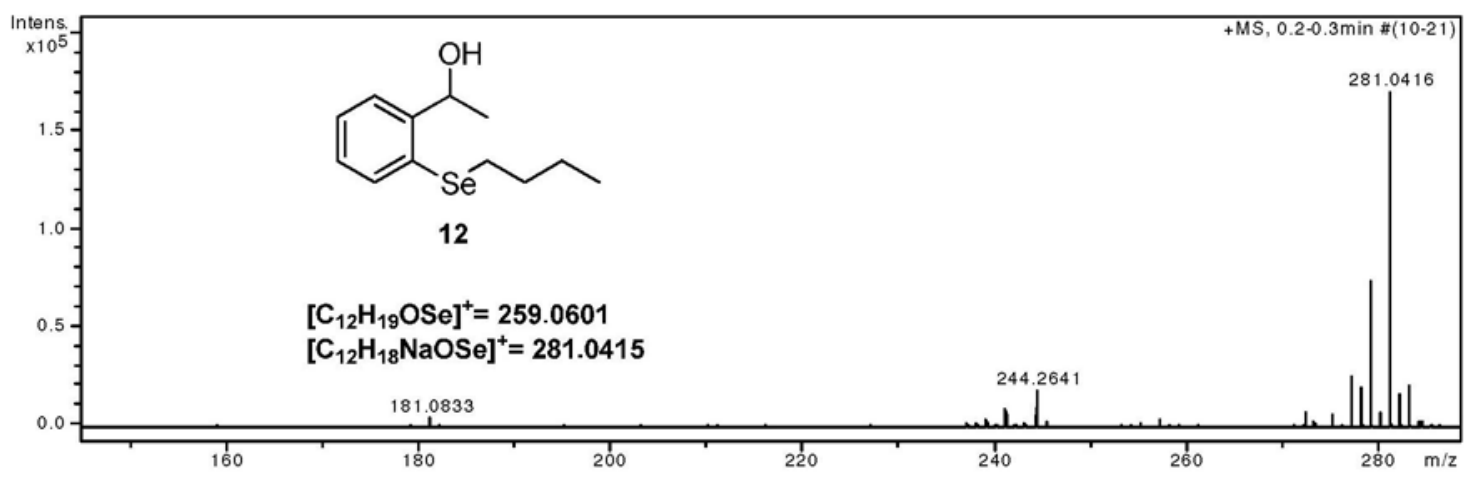

Figure S8. High resolution mass spectrum (ESI) of 1-(2-(butylselanyl)phenyl)ethanol (12).

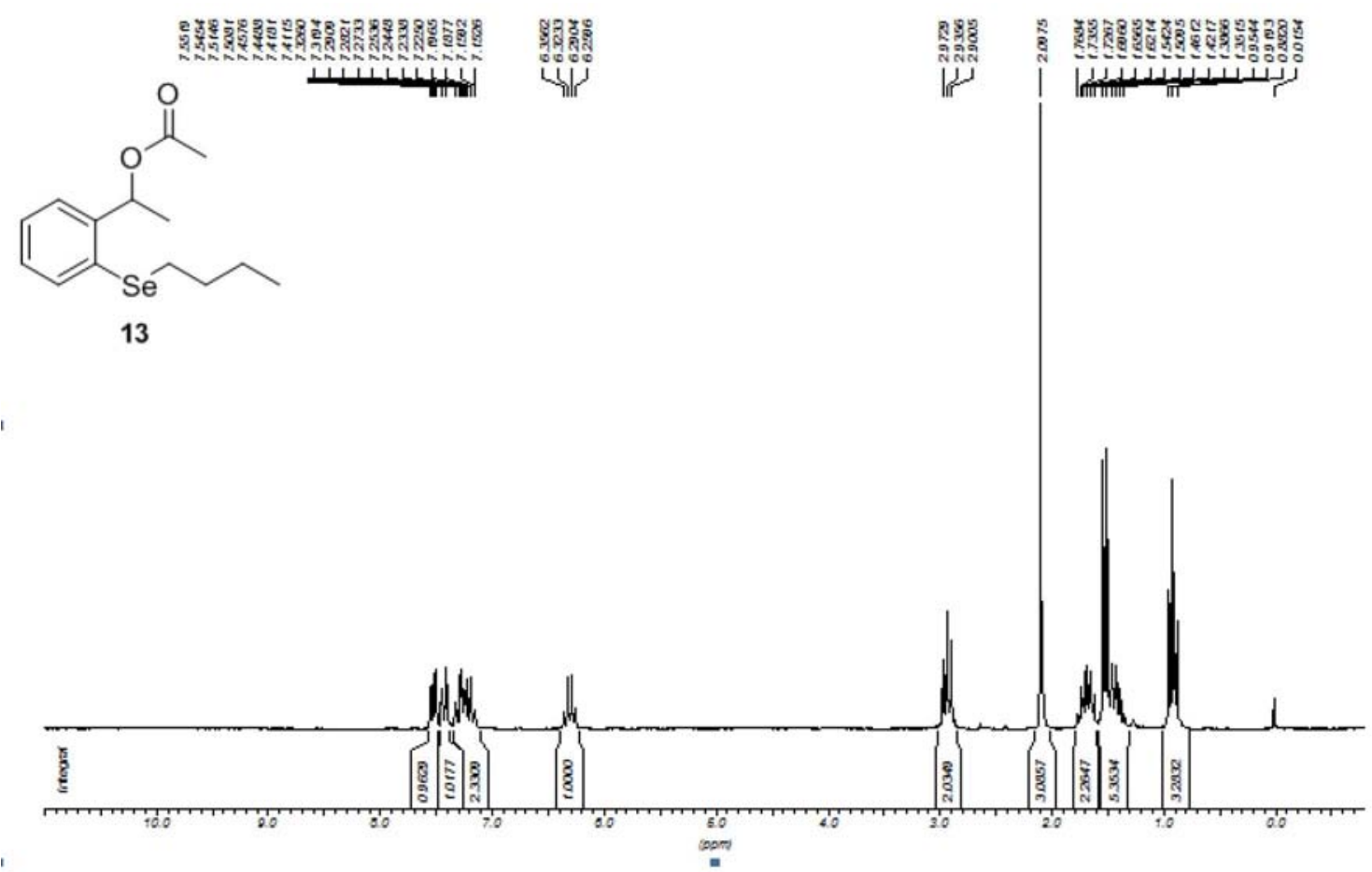

Figure S9. ${ }^{1} \mathrm{H}$ NMR $\left(200 \mathrm{MHz}, \mathrm{CDCl}_{3}\right.$ ) spectrum of 1-(2-(butylselanyl)phenyl)ethyl acetate (13). 


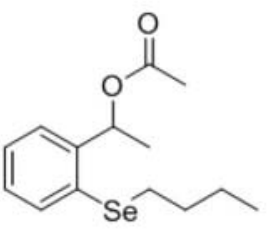

13
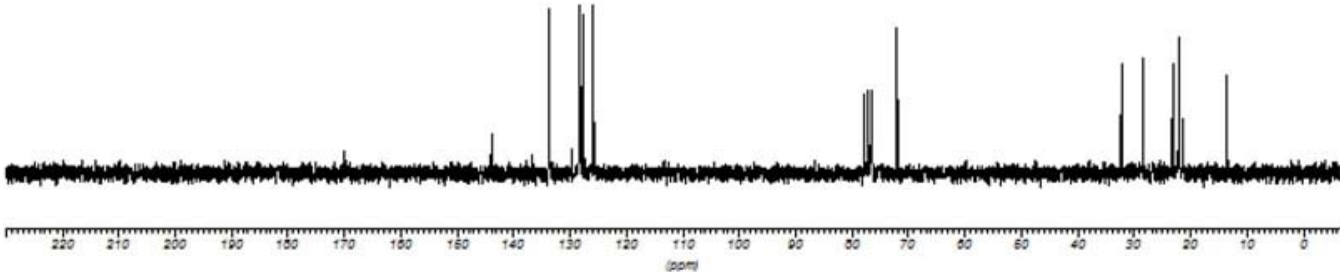

Figure S10. ${ }^{13} \mathrm{C}$ NMR (50 MHz, $\mathrm{CDCl}_{3}$ ) spectrum of 1-(2-(butylselanyl)phenyl)ethyl acetate (13).

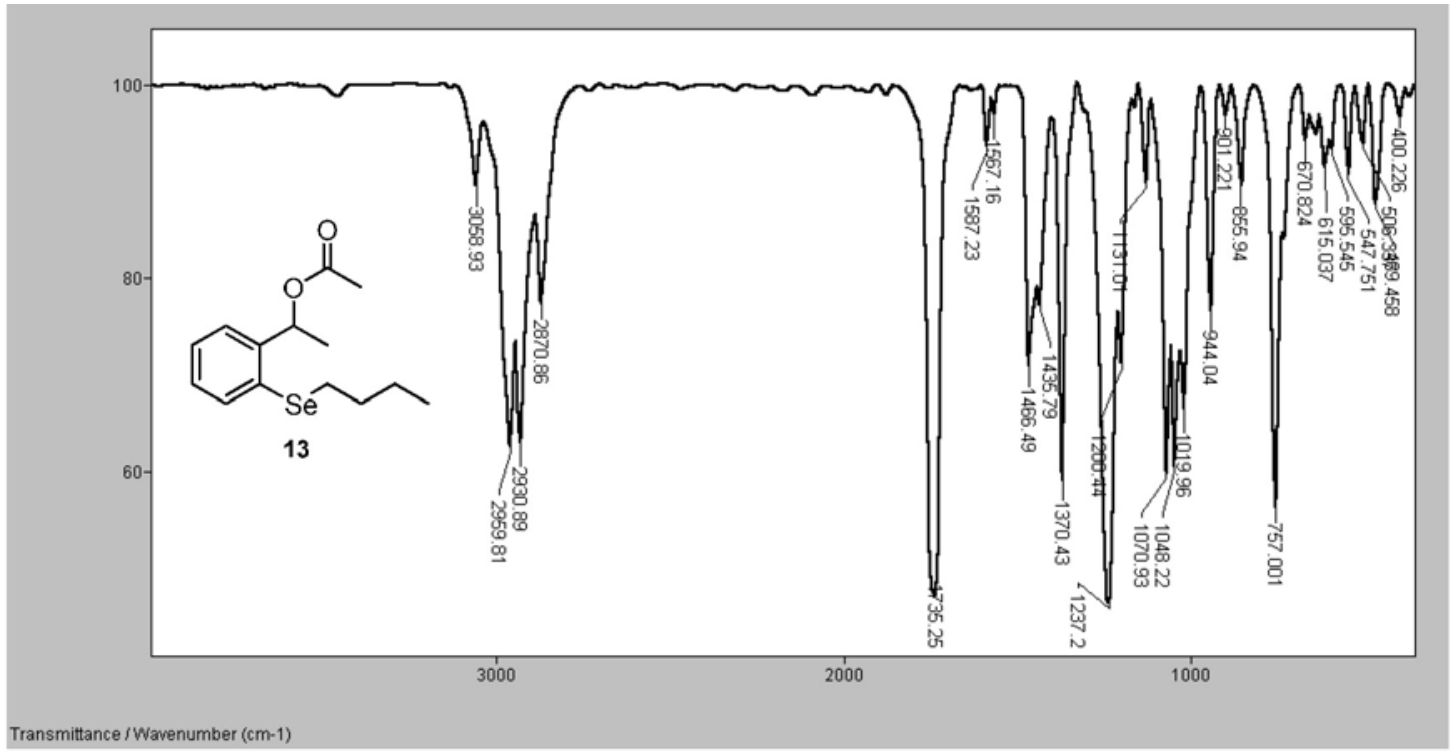

Figure S11. Infrared spectrum of 1-(2-(butylselanyl)phenyl)ethyl acetate (13). 


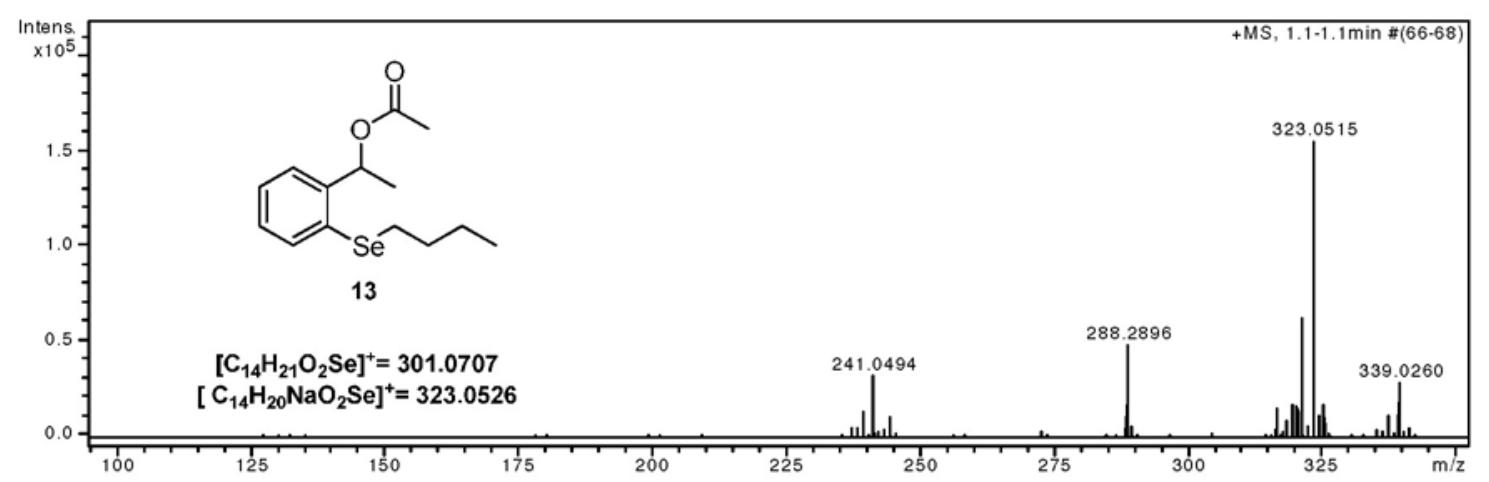

Figure S12. High resolution mass spectrum (ESI) of 1-(2-(butylselanyl)phenyl)ethyl acetate (13).

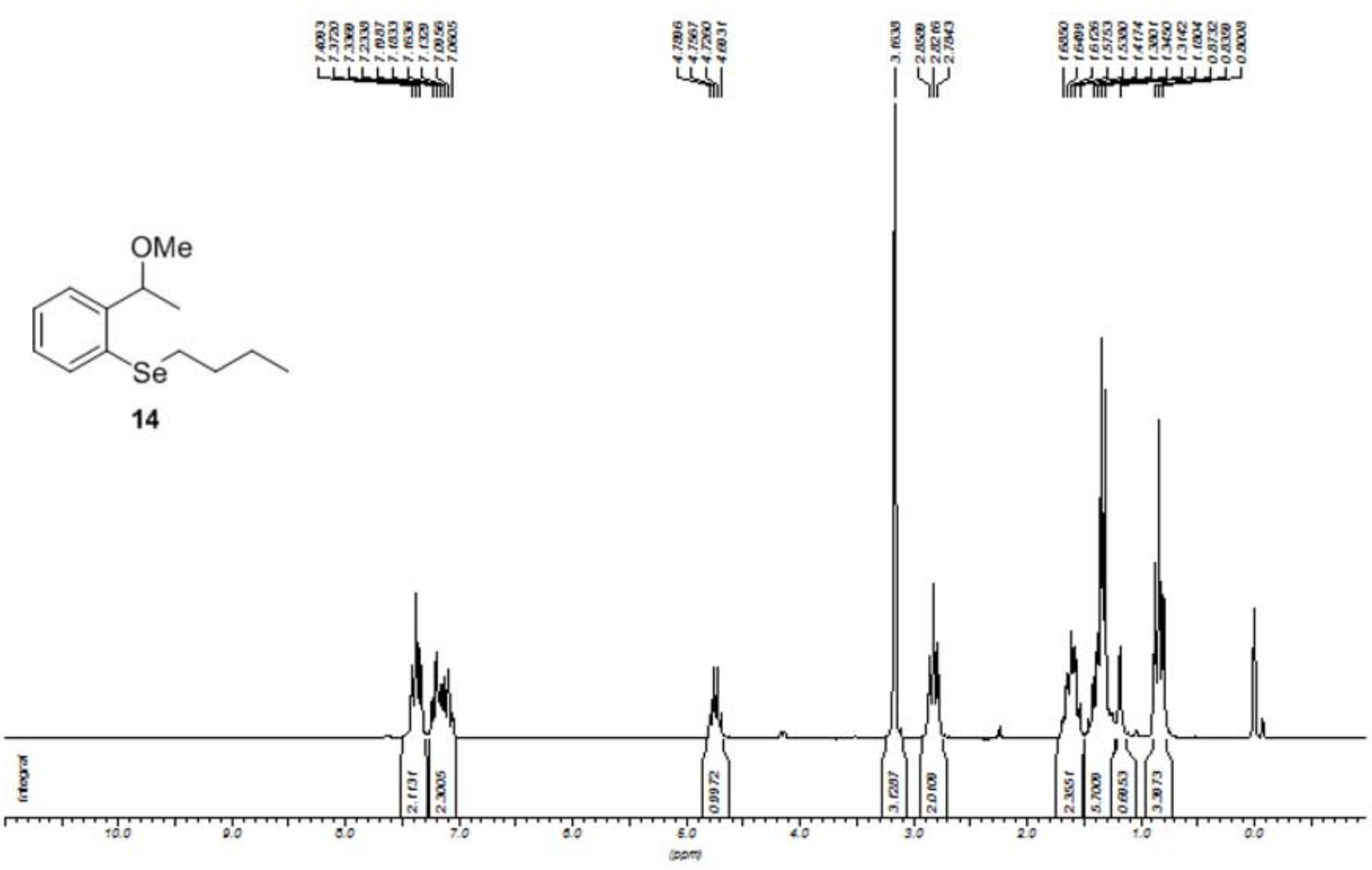

Figure S13. ${ }^{1} \mathrm{H}$ NMR (200 MHz, $\mathrm{CDCl}_{3}$ ) spectrum of butyl(2-(1-methoxyethyl)phenyl)selane (14). 


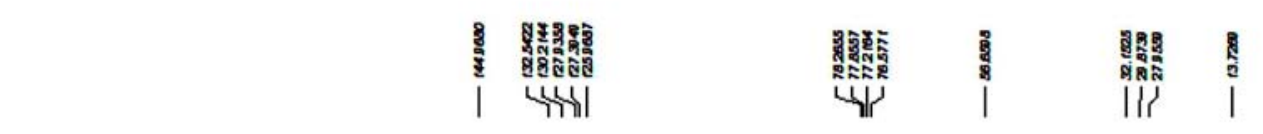<smiles>CCCC[Se]c1ccccc1C(C)O[Na]</smiles>

14

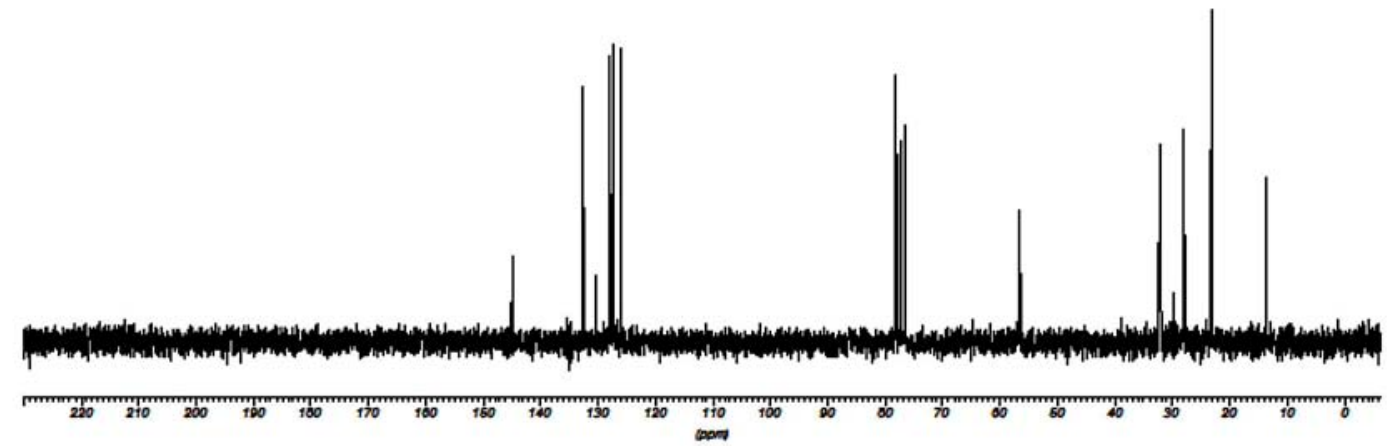

Figure S14. ${ }^{13} \mathrm{C}$ NMR (50 MHz, $\mathrm{CDCl}_{3}$ ) spectrum of butyl(2-(1-methoxyethyl)phenyl)selane (14).

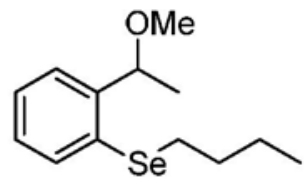

14

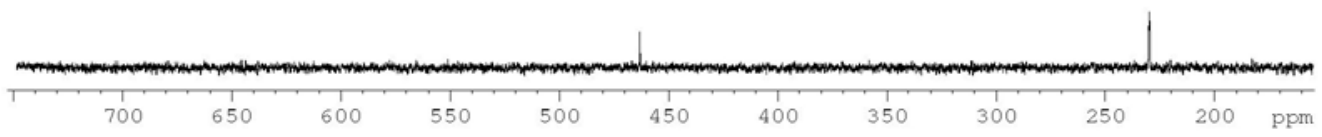

Figure S15. ${ }^{77} \mathrm{Se} \mathrm{NMR}\left(57.24 \mathrm{MHz}, \mathrm{CDCl}_{3}\right)$ spectrum of butyl(2-(1-methoxyethyl)phenyl)selane (14). 


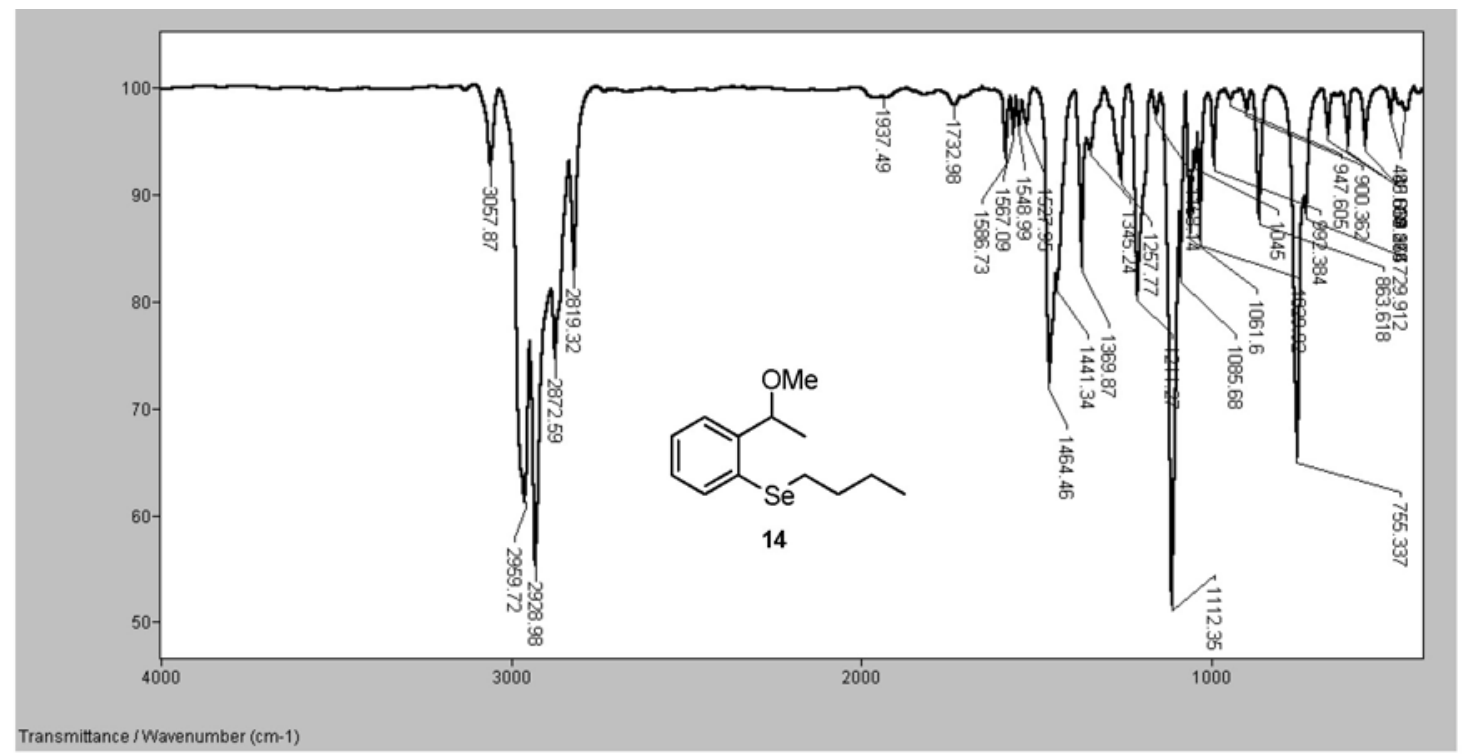

Figure S16. Infrared spectrum of butyl(2-(1-methoxyethyl)phenyl)selane (14).

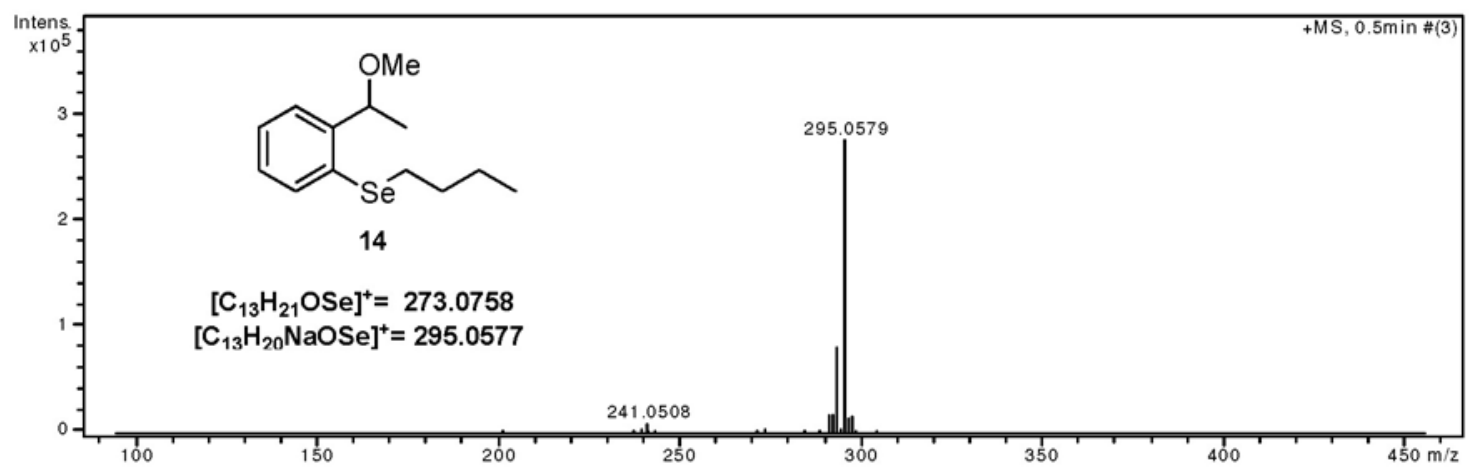

Figure S17. High resolution mass spectrum (ESI) of butyl(2-(1-methoxyethyl)phenyl)selane (14). 


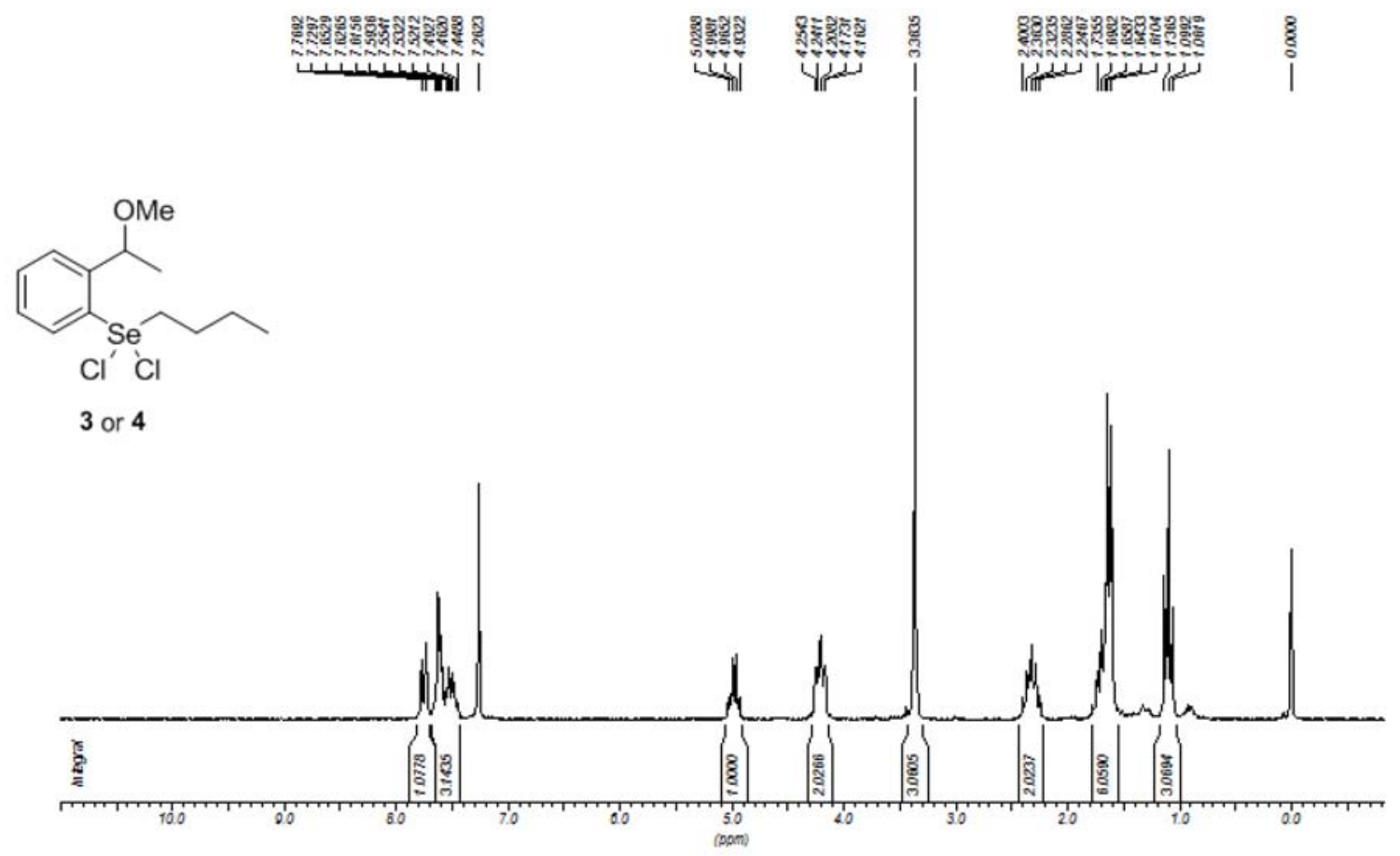

Figure S18. ${ }^{1} \mathrm{H}$ NMR $\left(200 \mathrm{MHz}, \mathrm{CDCl}_{3}\right)$ spectrum of selenane $(\mathbf{3}$ or $\mathbf{4})$.

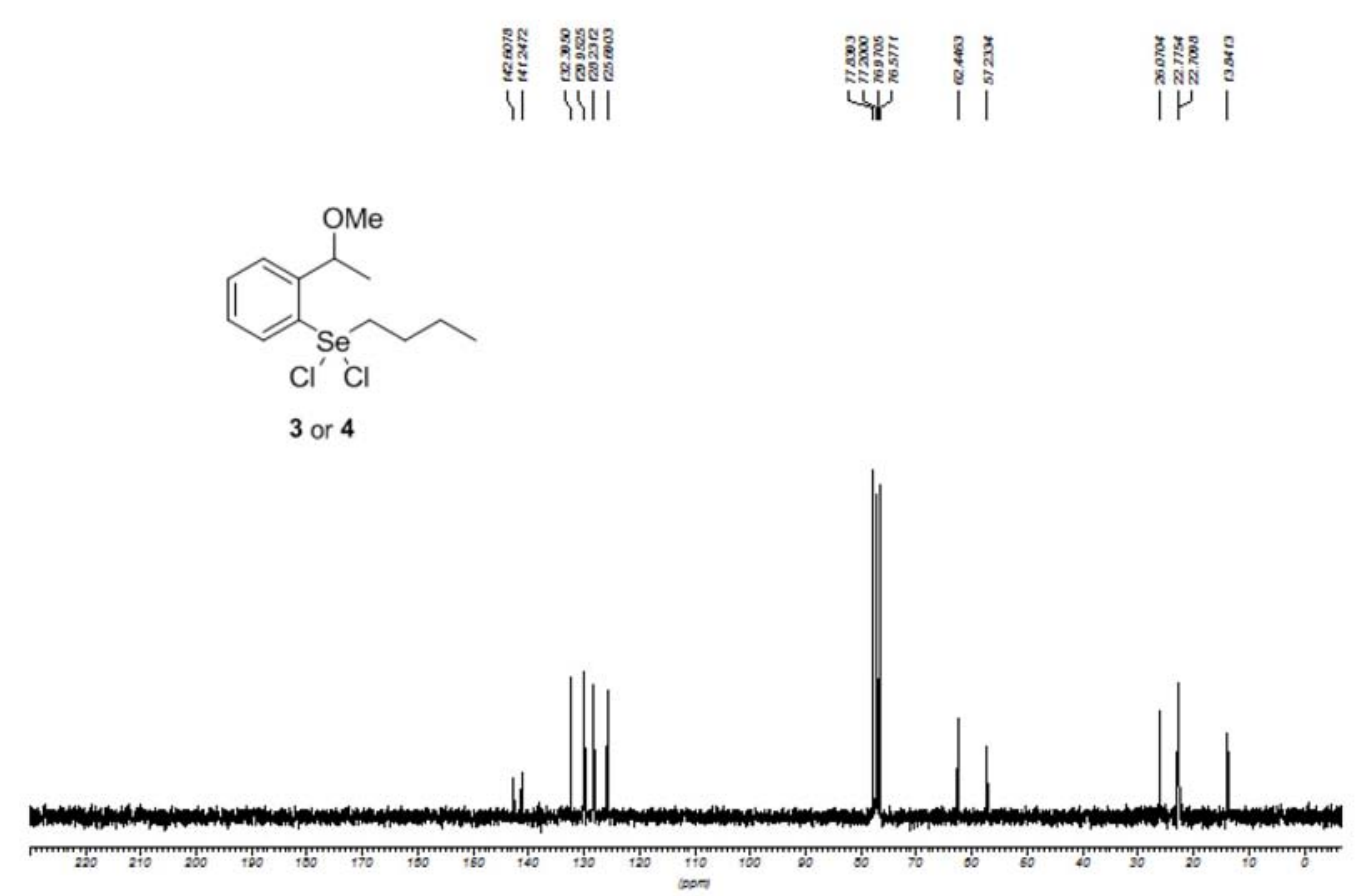

Figure S19. ${ }^{13} \mathrm{C}$ NMR $\left(50 \mathrm{MHz}, \mathrm{CDCl}_{3}\right)$ spectrum of selenane (3 or 4). 


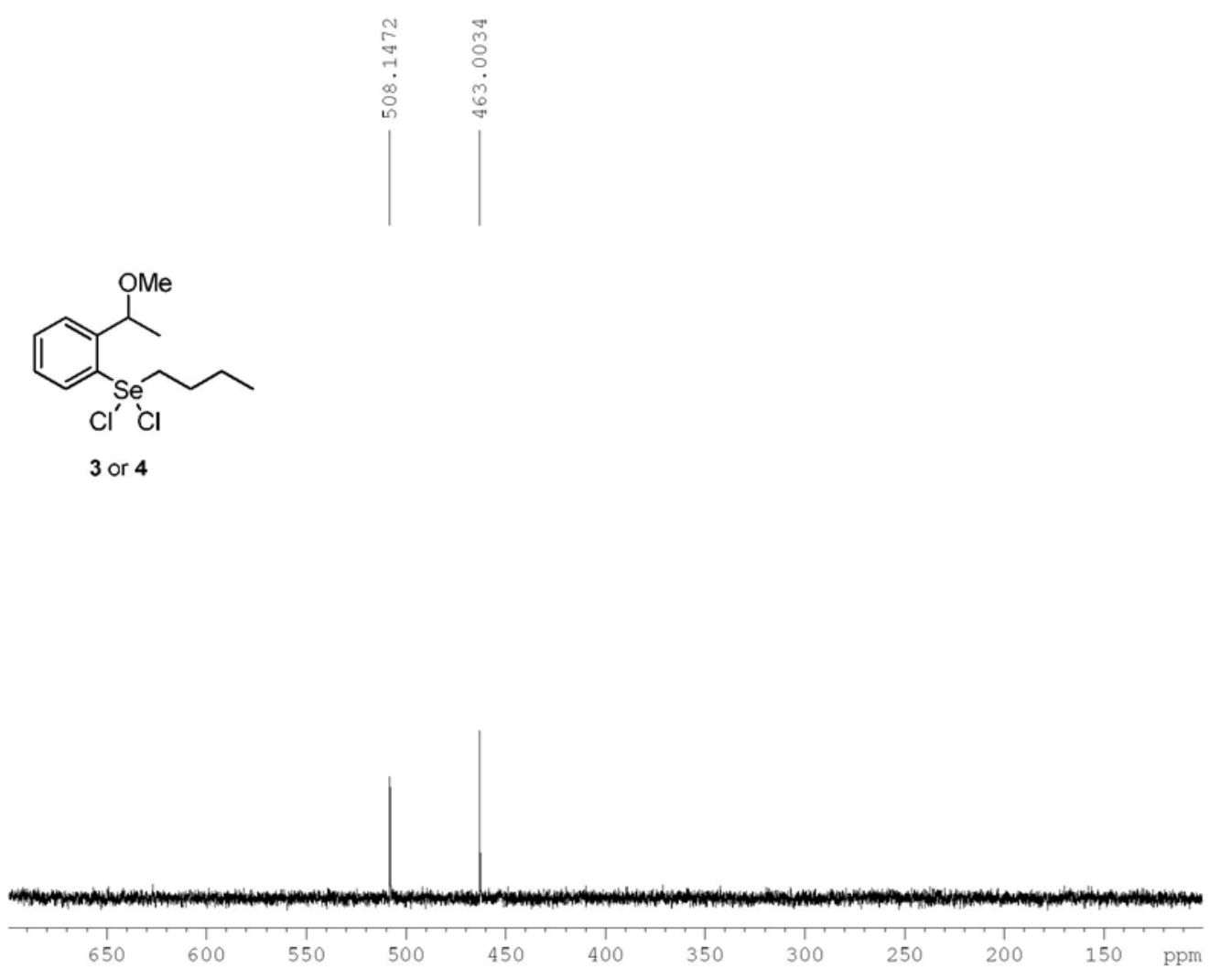

Figure S20. ${ }^{77} \mathrm{Se} \mathrm{NMR}\left(57.24 \mathrm{MHz}, \mathrm{CDCl}_{3}\right)$ spectrum of selenane (3 or 4).

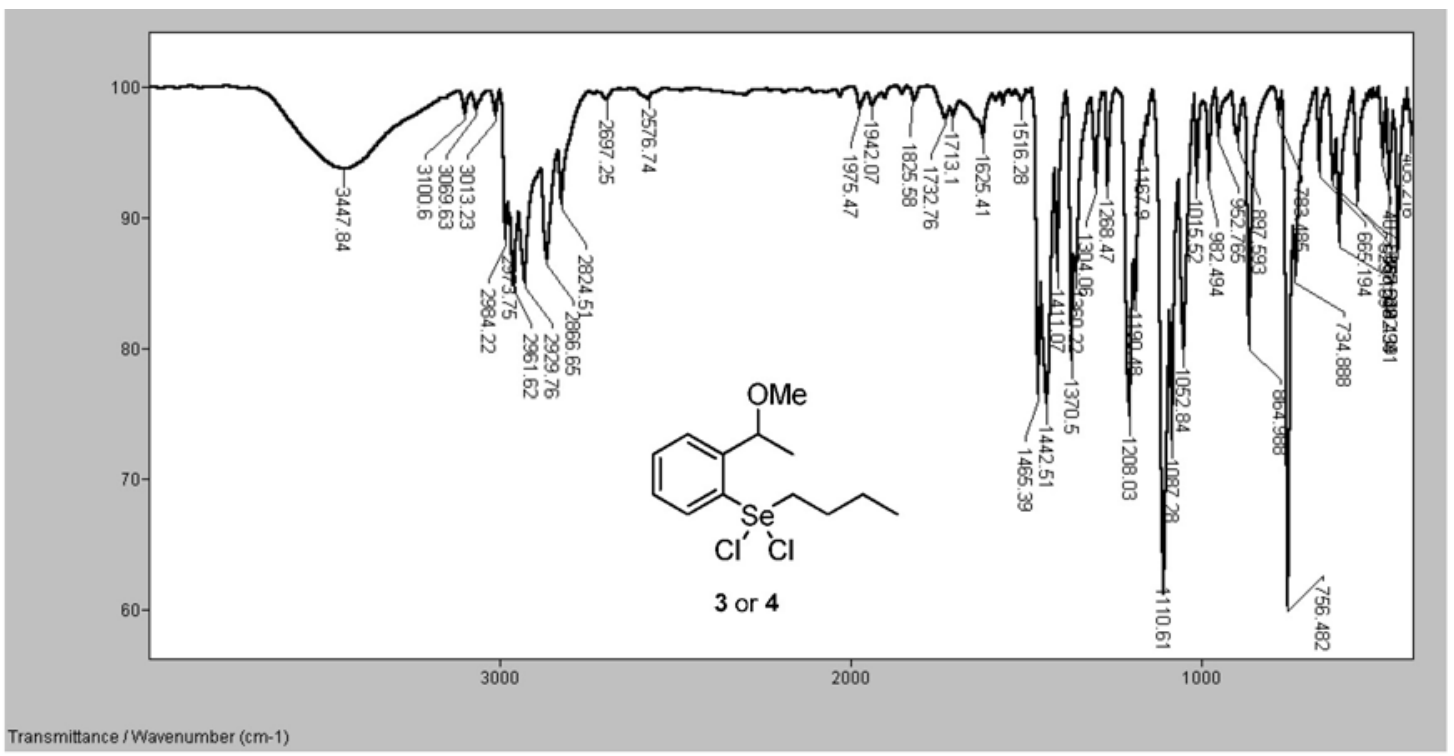

Figure S21. Infrared spectrum of selenane (3 or $\mathbf{4})$. 


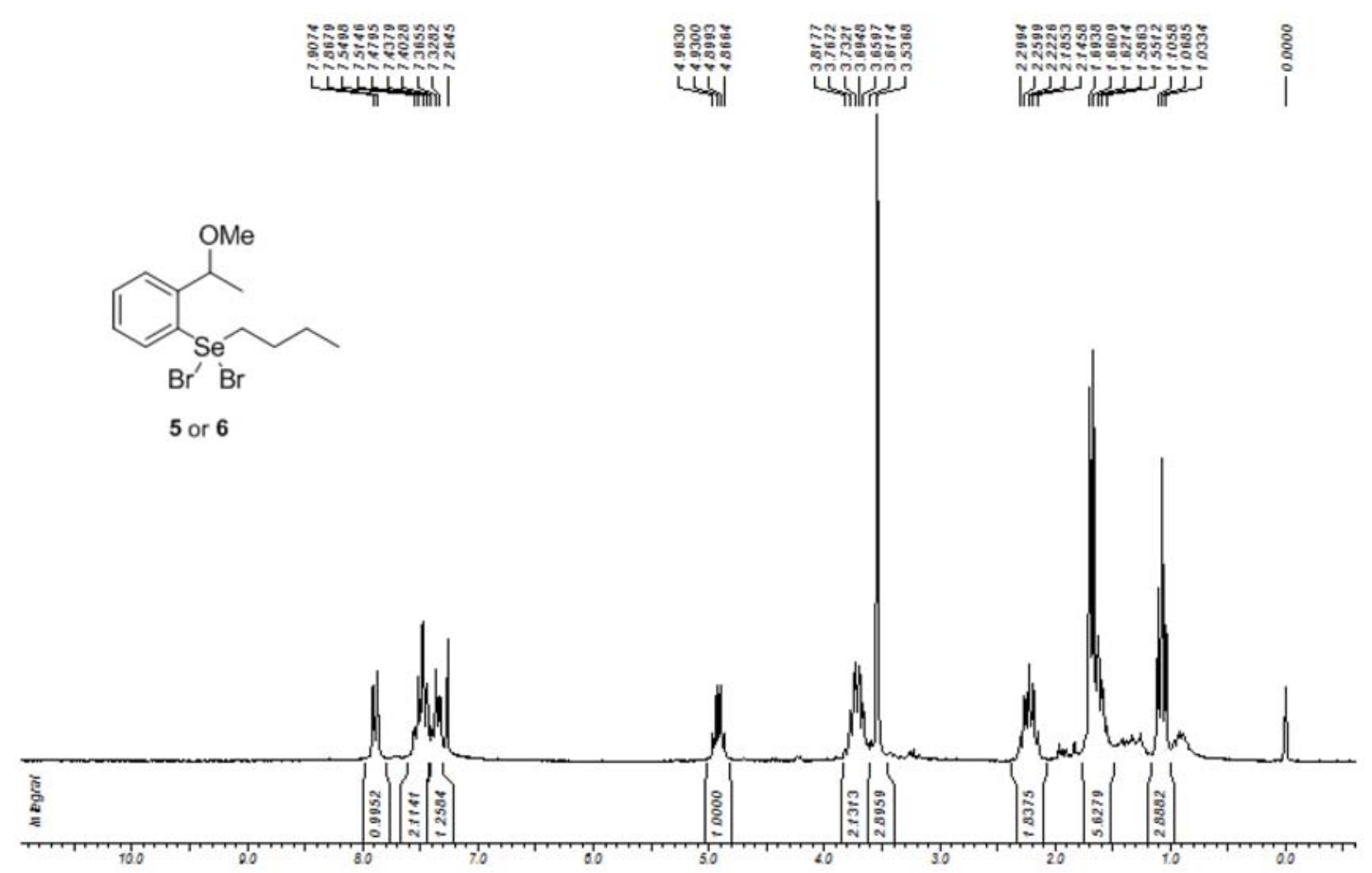

Figure S22. ${ }^{1} \mathrm{H}$ NMR $\left(200 \mathrm{MHz}, \mathrm{CDCl}_{3}\right.$ ) spectrum of selenane (5 or $\left.\mathbf{6}\right)$.

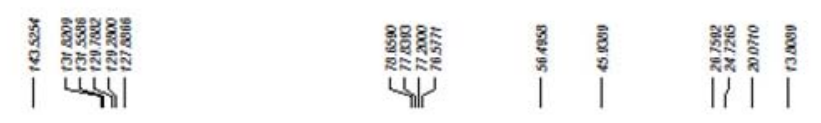

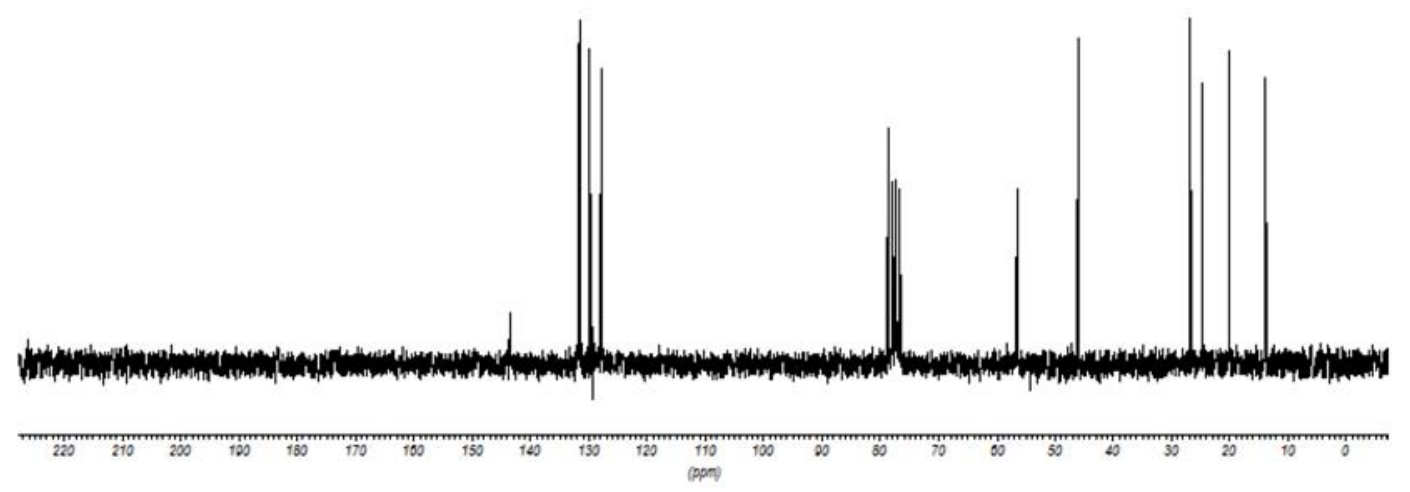

Figure S23. ${ }^{13} \mathrm{C}$ NMR $\left(50 \mathrm{MHz}, \mathrm{CDCl}_{3}\right)$ spectrum of selenane (5 or $\left.\mathbf{6}\right)$. 


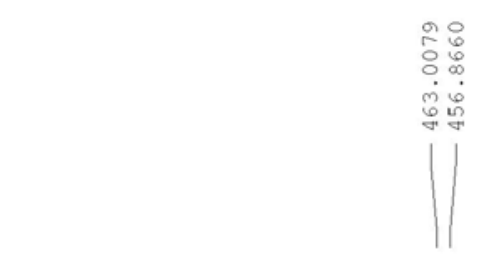<smiles>CCCC[Se](Br)(Br)c1ccccc1C(C)OC</smiles>

5 or 6

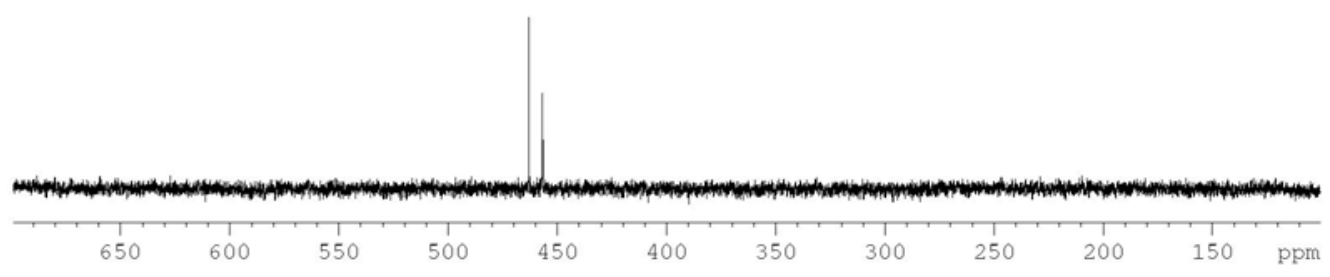

Figure S24. ${ }^{77} \mathrm{Se} \mathrm{NMR}\left(57.24 \mathrm{MHz}, \mathrm{CDCl}_{3}\right)$ spectrum of selenane (5 or 6).

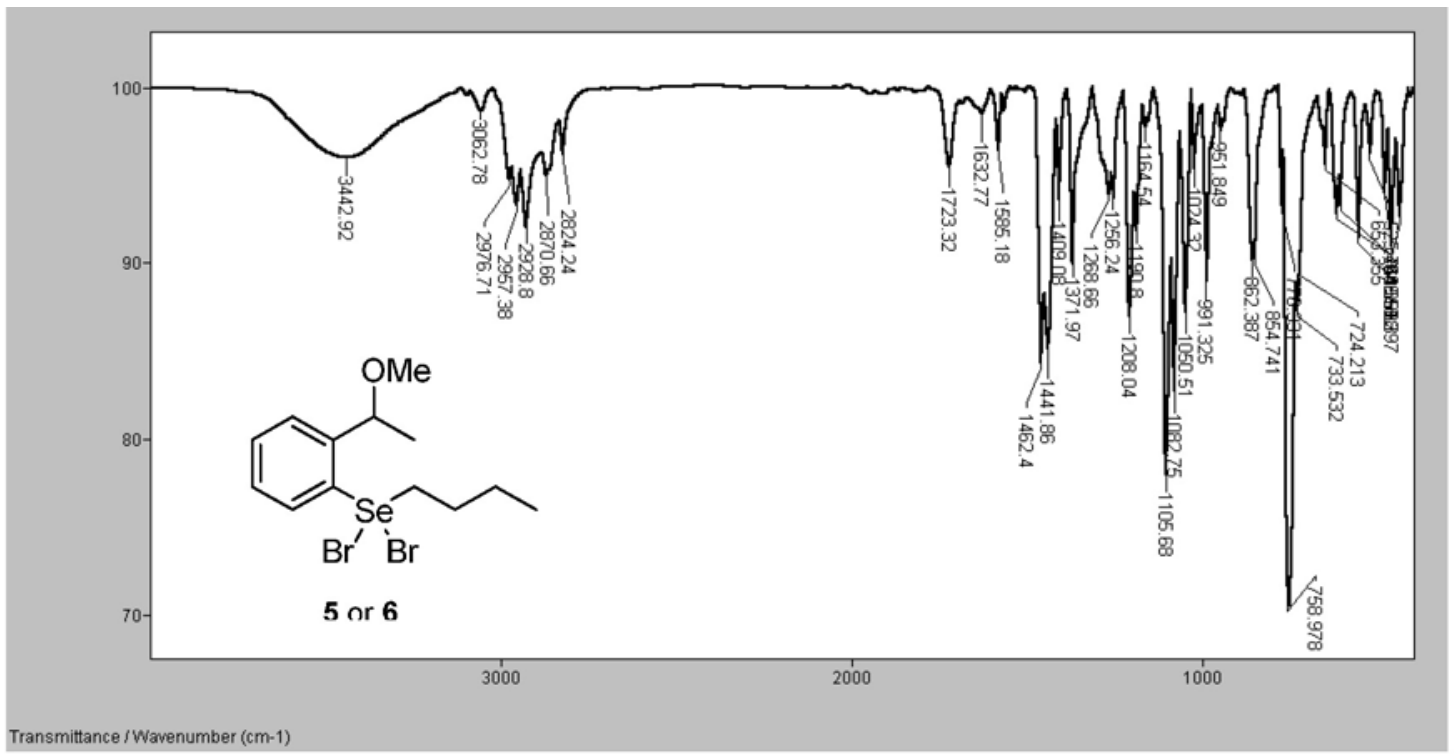

Figure S25. Infrared spectrum of selenane (5 or $\mathbf{6})$. 

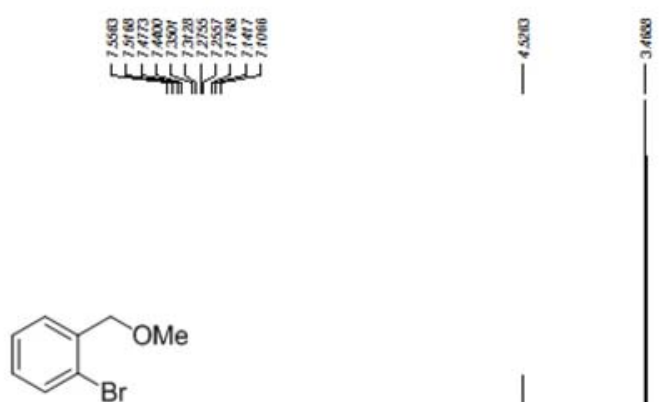

8

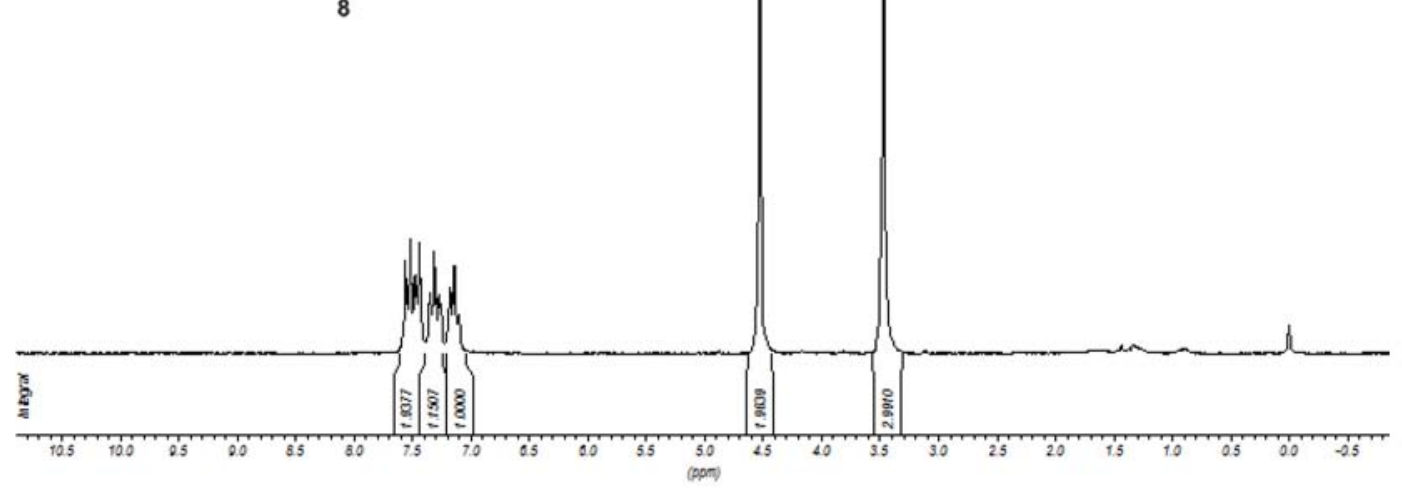

Figure S26. ${ }^{1} \mathrm{H}$ NMR (200 MHz, $\mathrm{CDCl}_{3}$ ) spectrum of 1-bromo-2-(methoxymethyl)benzene (8).
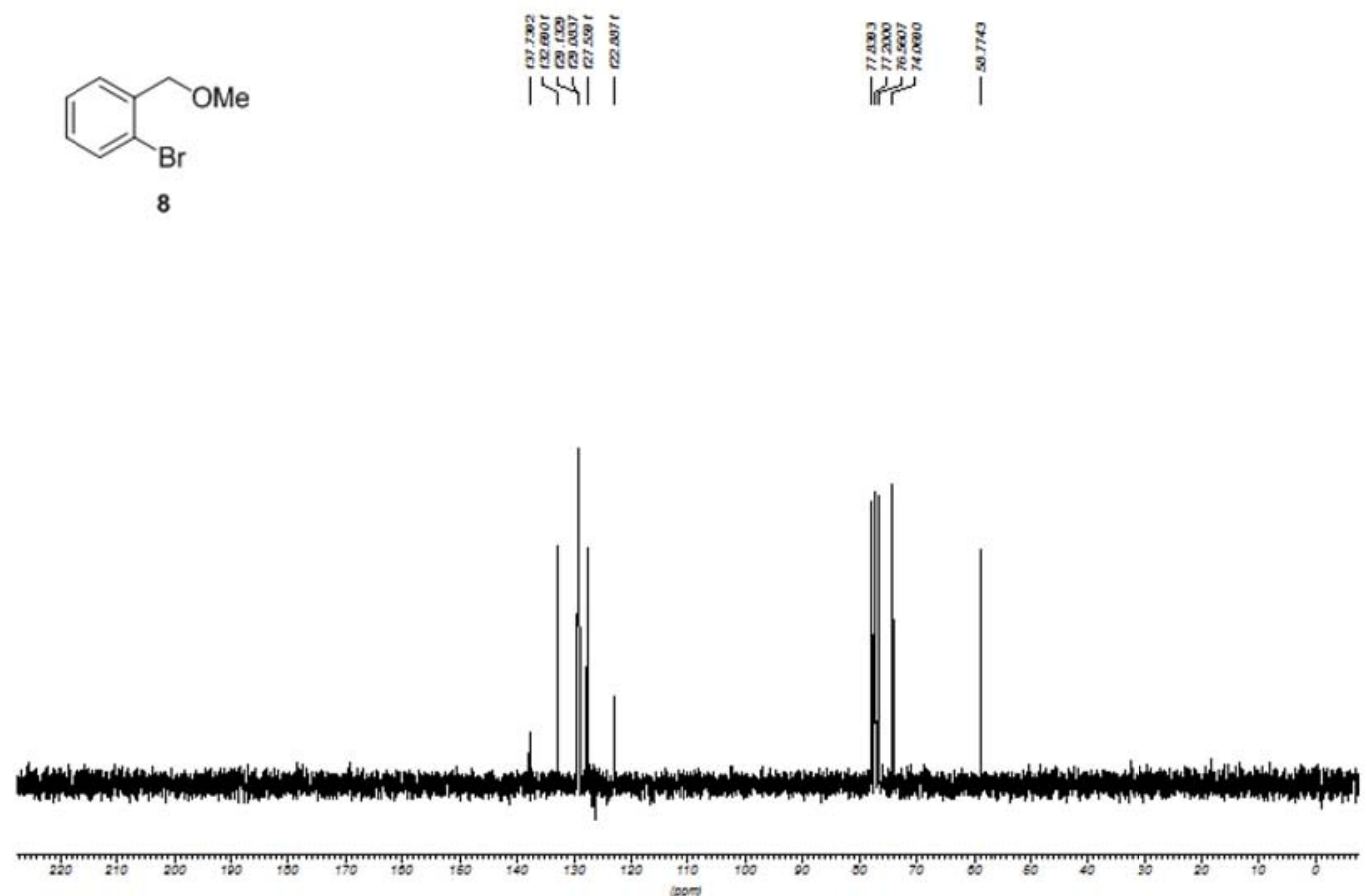

Figure S27. ${ }^{13} \mathrm{C}$ NMR $\left(50 \mathrm{MHz}, \mathrm{CDCl}_{3}\right)$ spectrum of 1-bromo-2-(methoxymethyl)benzene (8). 


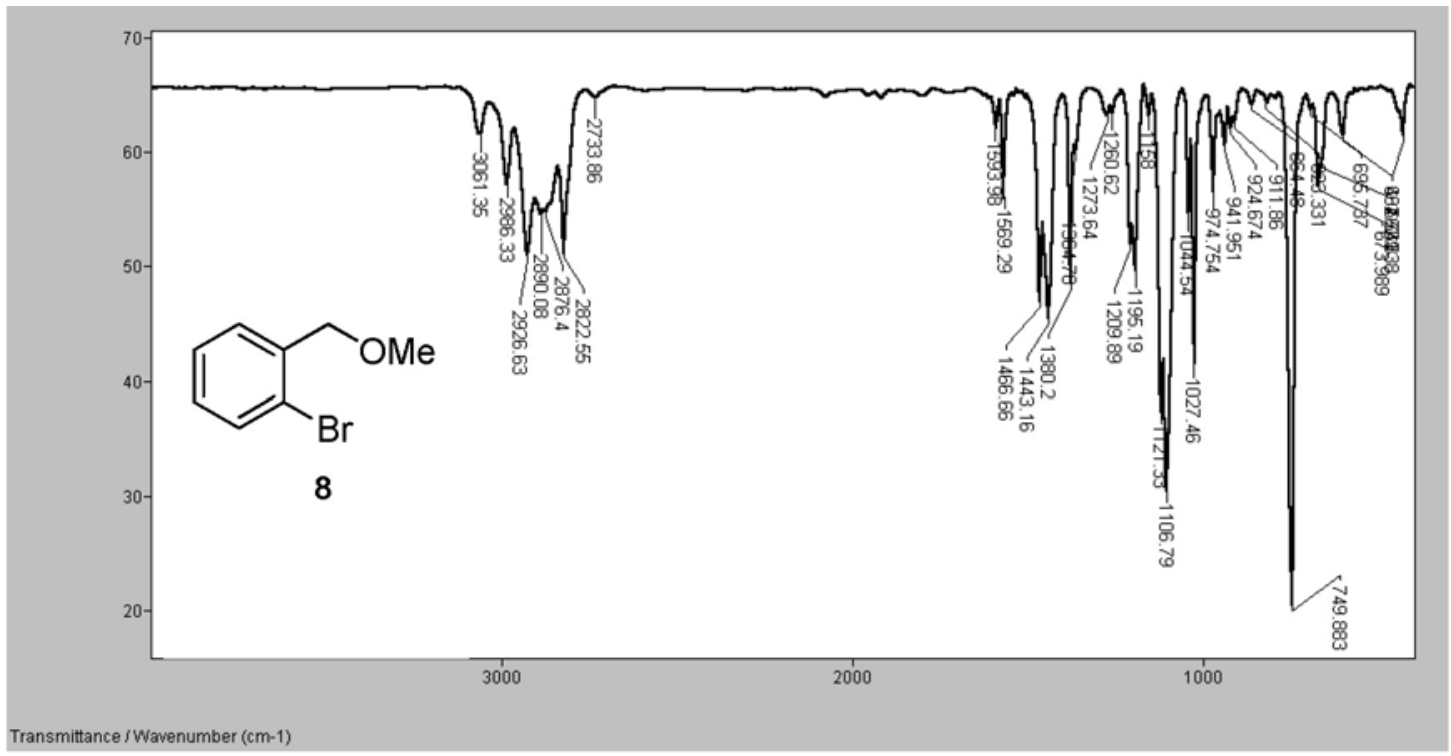

Figure S28. Infrared spectrum of 1-bromo-2-(methoxymethyl)benzene (8).

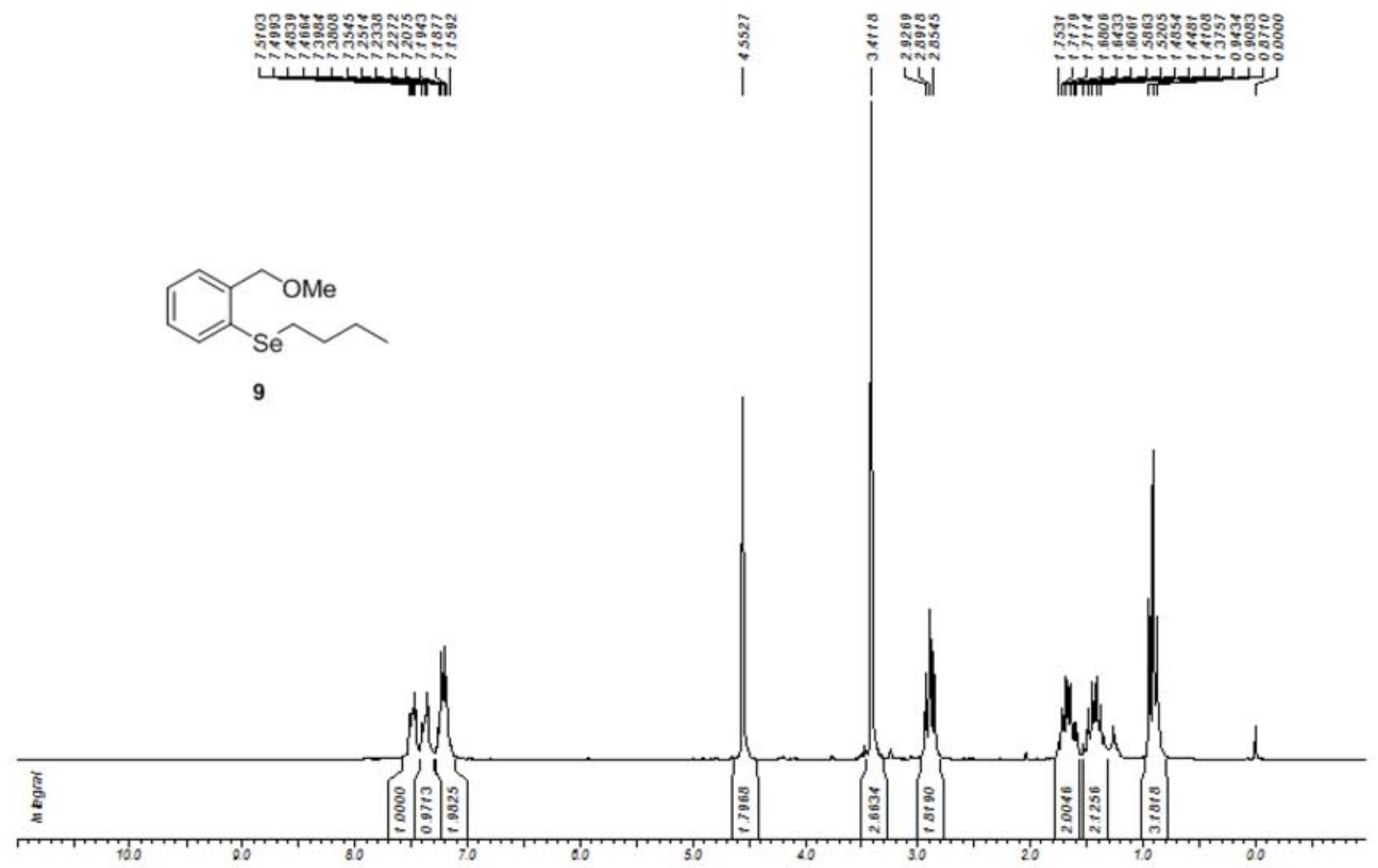

Figure S29. 'H NMR (200 MHz, $\mathrm{CDCl}_{3}$ ) spectrum of butyl(2-(methoxymethyl)phenyl)selane (9). 

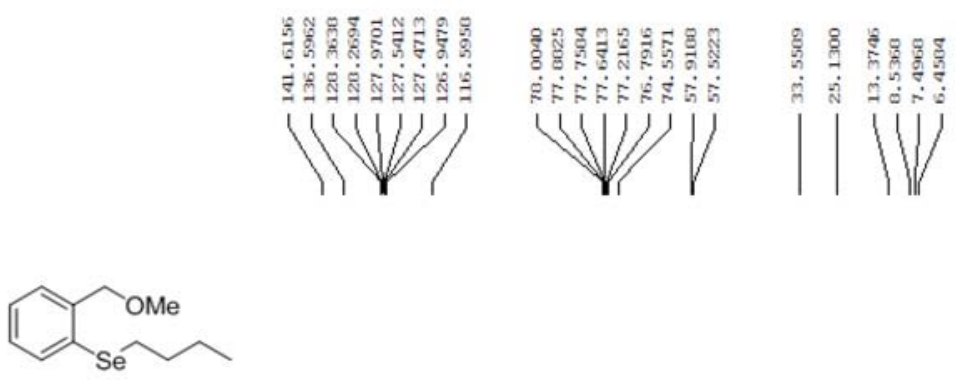

9

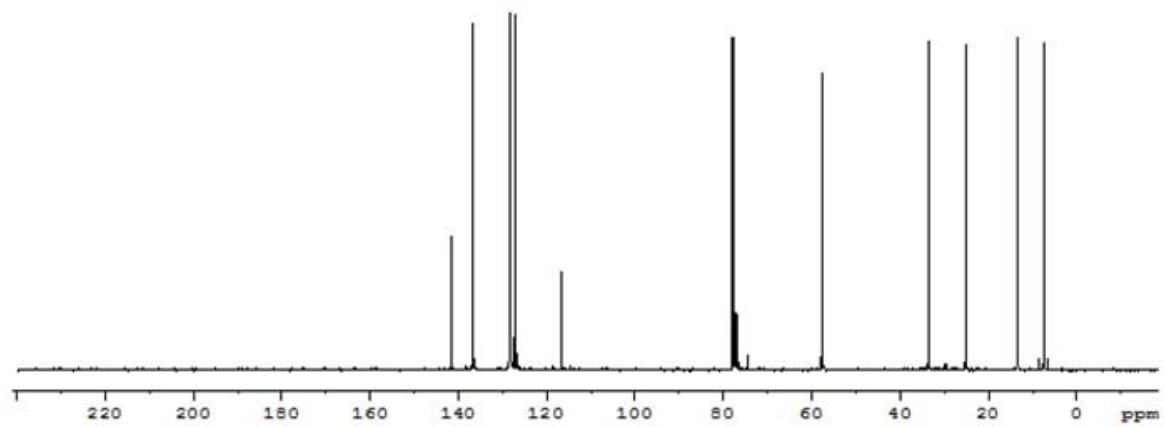

Figure S30. ${ }^{13} \mathrm{C}$ NMR $\left(75 \mathrm{MHz}, \mathrm{CDCl}_{3}\right.$ ) spectrum of butyl(2-(methoxymethyl)phenyl)selane (9).
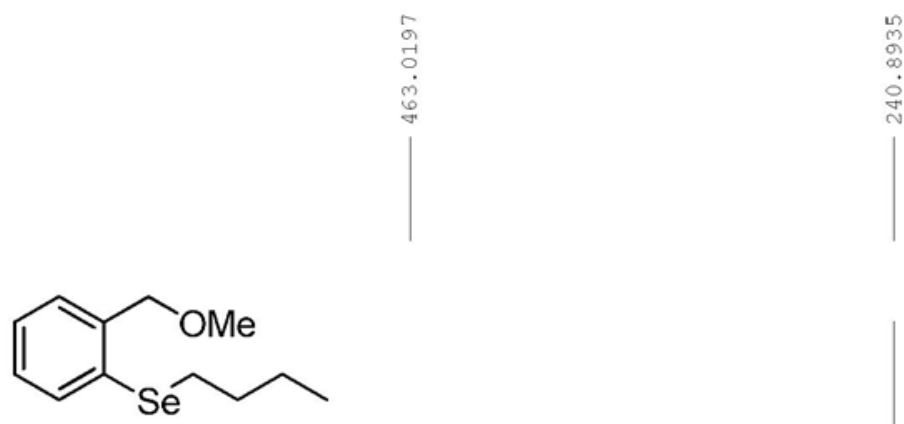

9

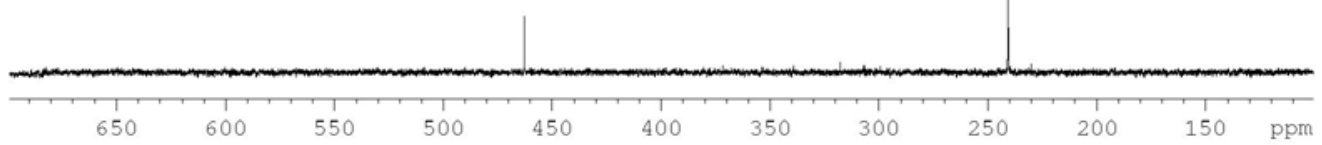

Figure S31. ${ }^{77} \mathrm{Se} \mathrm{NMR}\left(57.24 \mathrm{MHz}, \mathrm{CDCl}_{3}\right.$ ) spectrum of butyl(2-(methoxymethyl)phenyl)selane (9). 


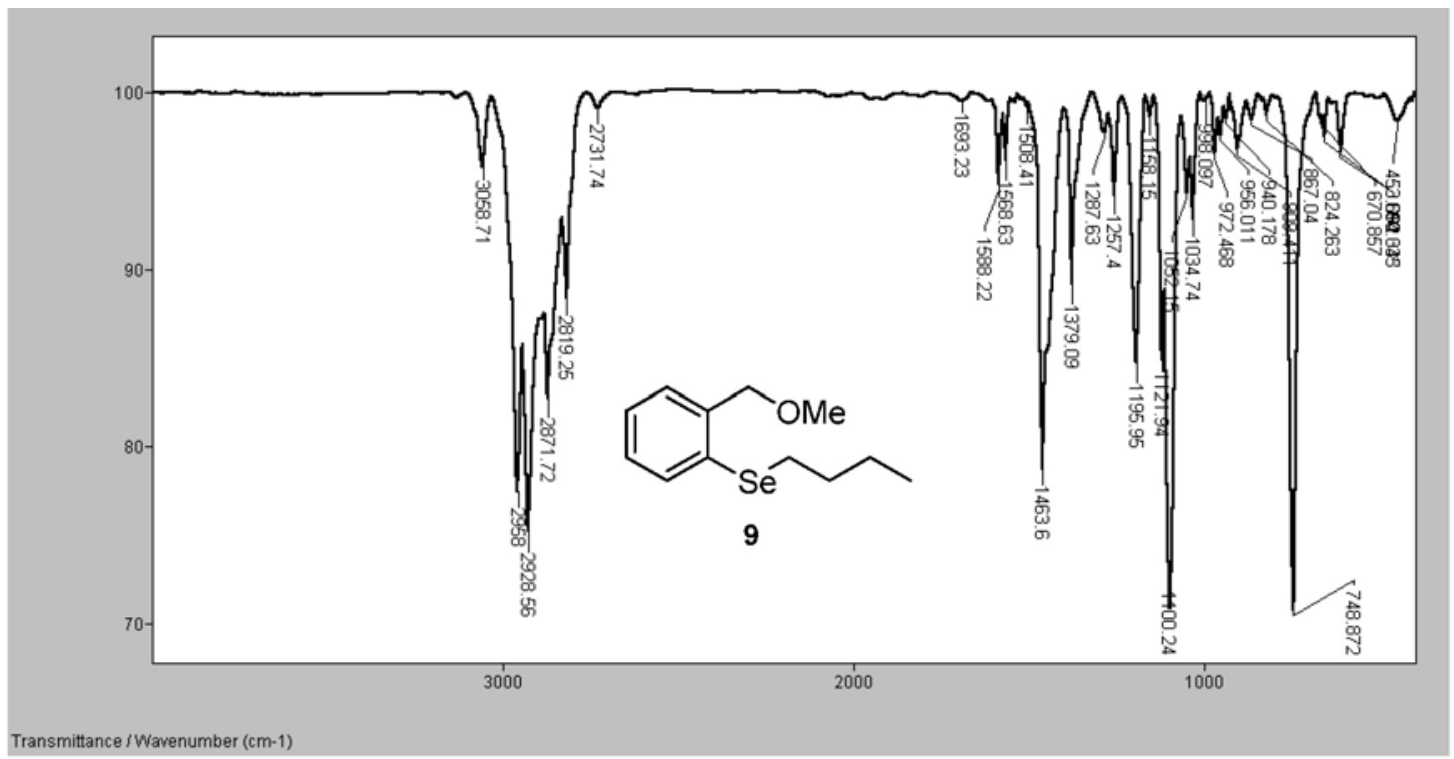

Figure S32. Infrared spectrum of butyl(2-(methoxymethyl)phenyl)selane (9).

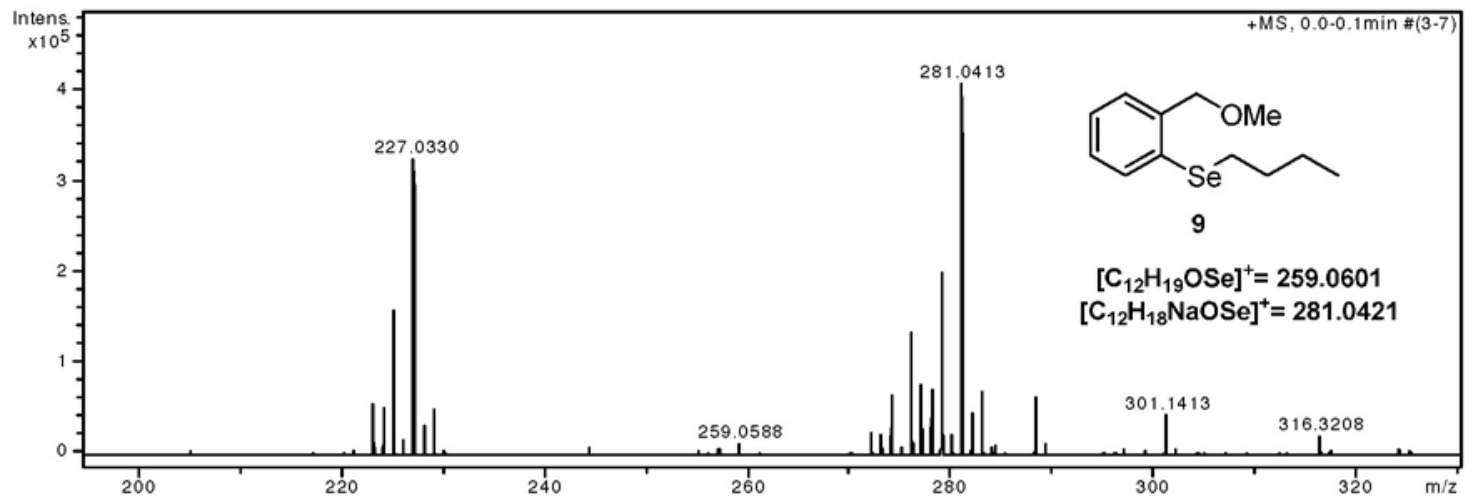

Figure S33. High resolution mass spectrum (ESI) of butyl(2-(methoxymethyl)phenyl)selane (9). 


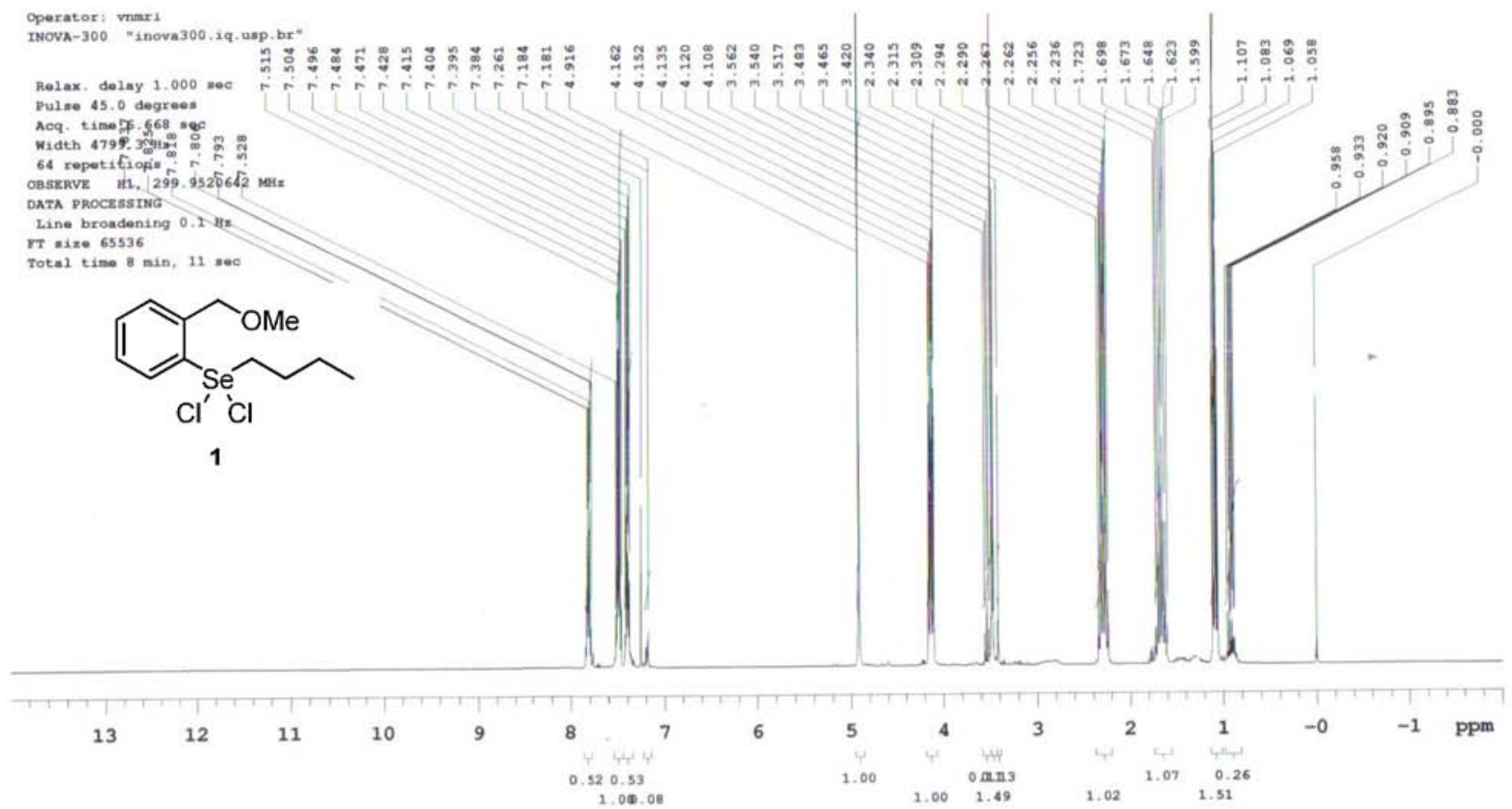

Figure S34. ${ }^{1} \mathrm{H}$ NMR $\left(200 \mathrm{MHz}, \mathrm{CDCl}_{3}\right)$ spectrum of selenane $\mathbf{1}$.

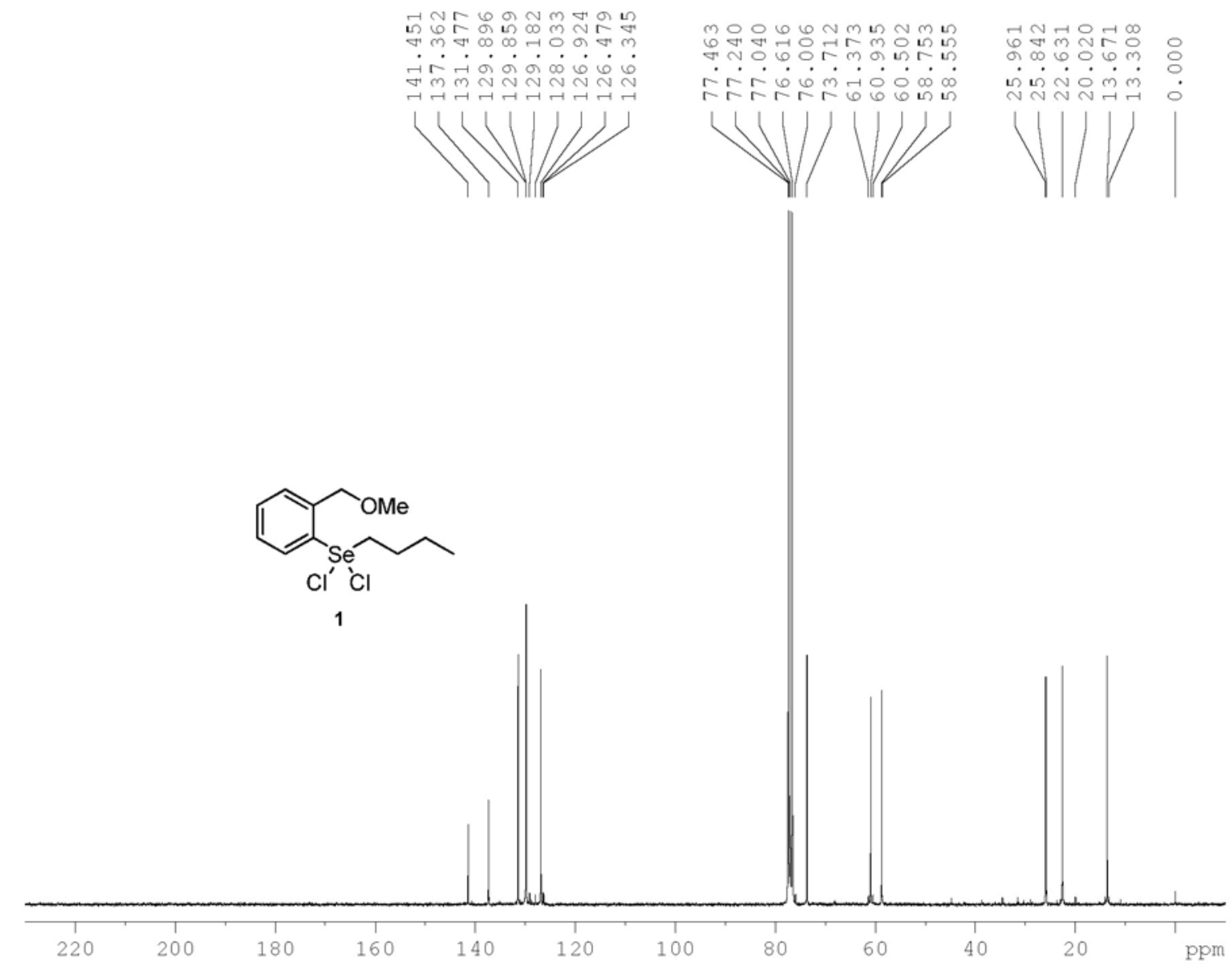

Figure S35. ${ }^{13} \mathrm{C}$ NMR $\left(75 \mathrm{MHz}, \mathrm{CDCl}_{3}\right)$ spectrum of selenane 1 . 


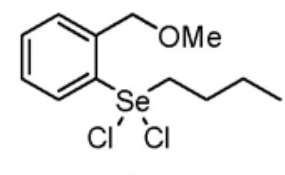

1

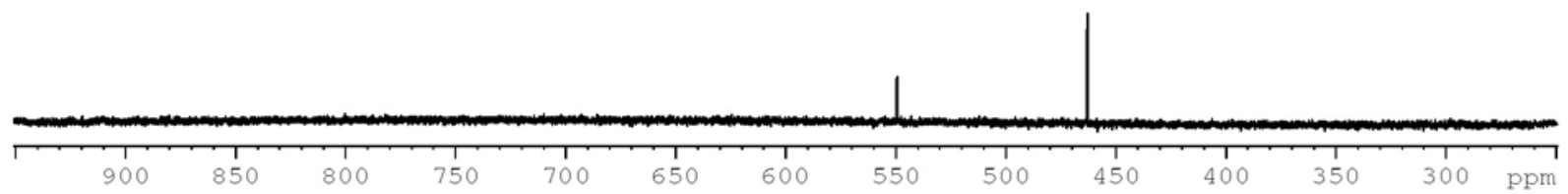

Figure S36. ${ }^{77} \mathrm{Se} \mathrm{NMR}\left(57.24 \mathrm{MHz}, \mathrm{CDCl}_{3}\right)$ spectrum of selenane $\mathbf{1}$.

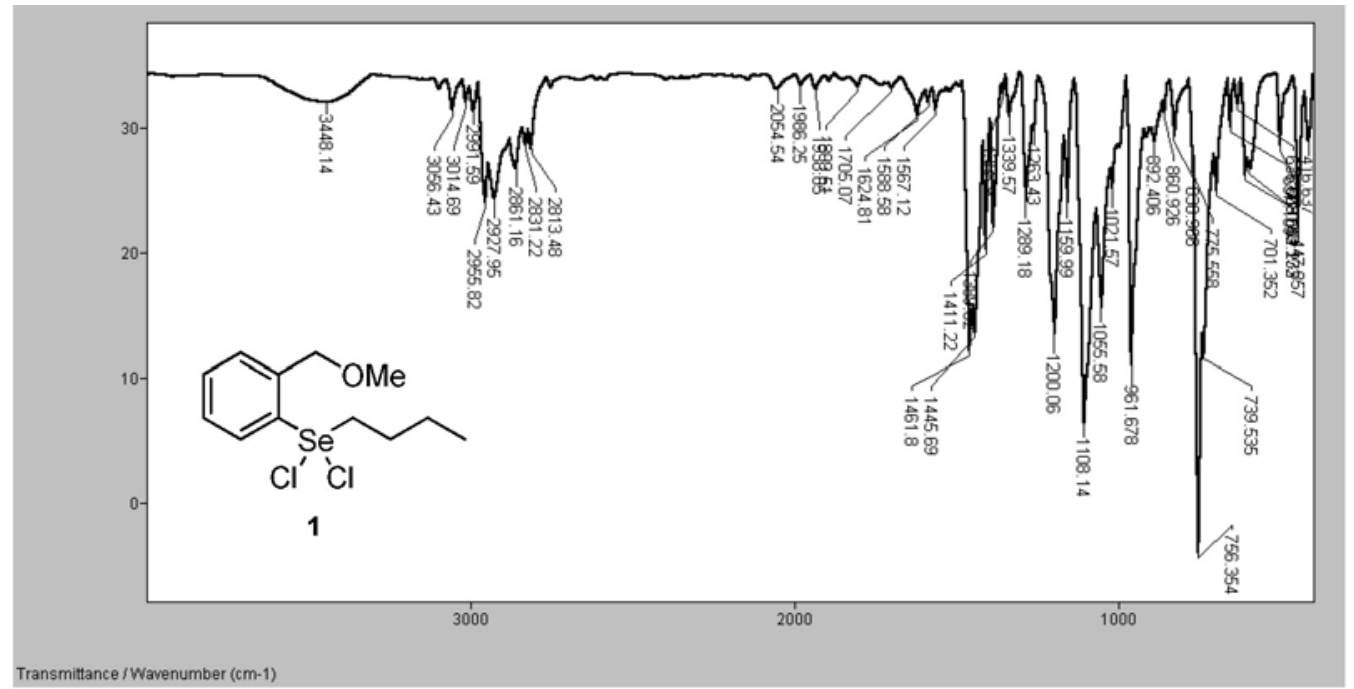

Figure S37. Infrared spectrum of selenane 1. 


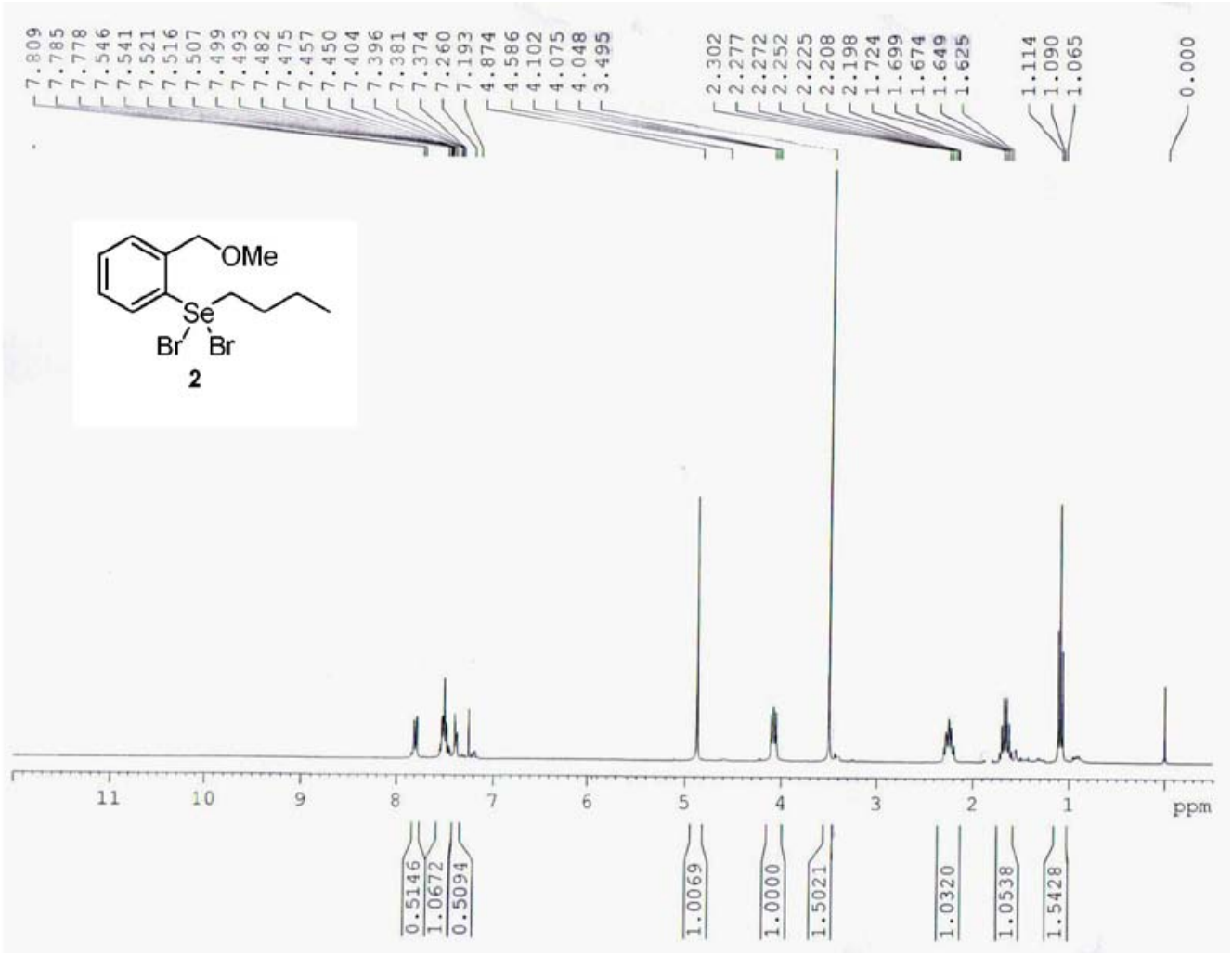

Figure S38. ${ }^{1} \mathrm{H}$ NMR $\left(300 \mathrm{MHz}, \mathrm{CDCl}_{3}\right)$ spectrum of selenane 2.

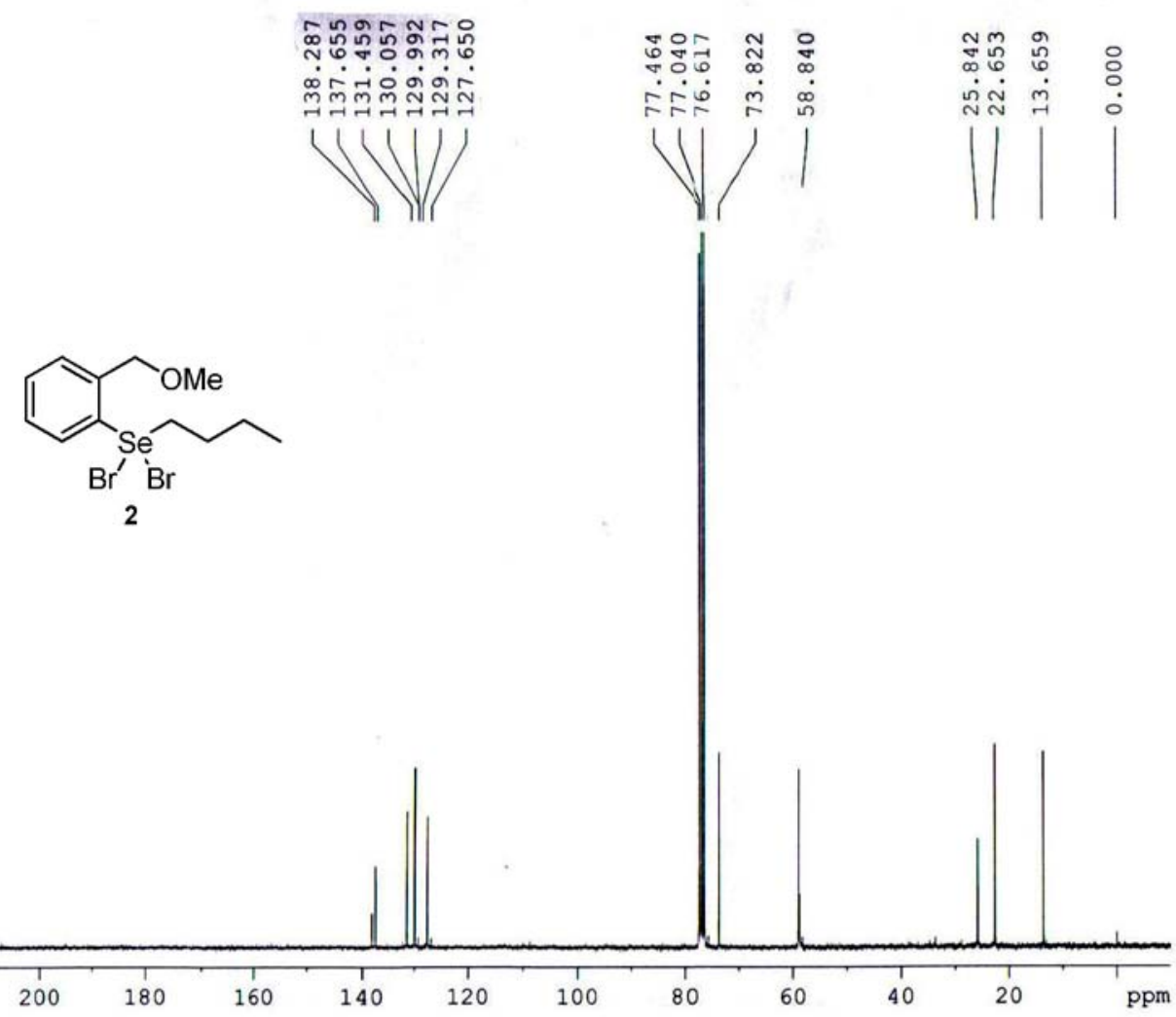

Figure S39. ${ }^{13} \mathrm{C}$ NMR $\left(75 \mathrm{MHz}, \mathrm{CDCl}_{3}\right)$ spectrum of selenane 2 . 

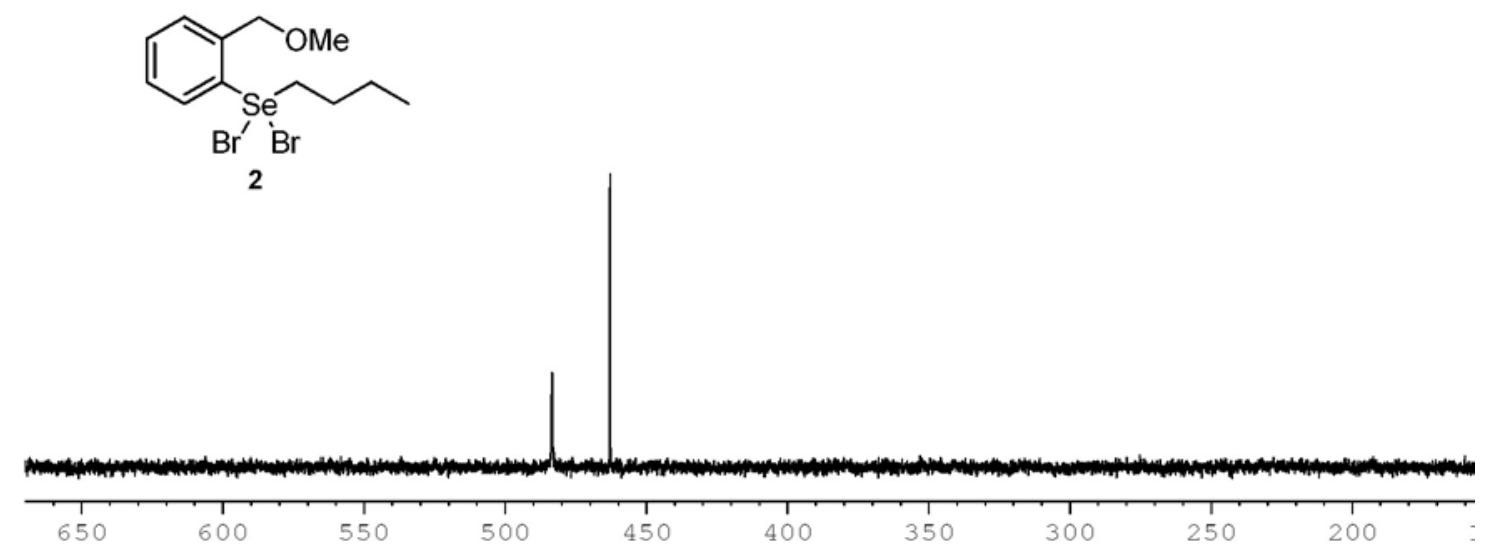

Figure S40. ${ }^{77} \mathrm{Se} \mathrm{NMR}\left(57.24 \mathrm{MHz}, \mathrm{CDCl}_{3}\right)$ spectrum of selenane 2 .

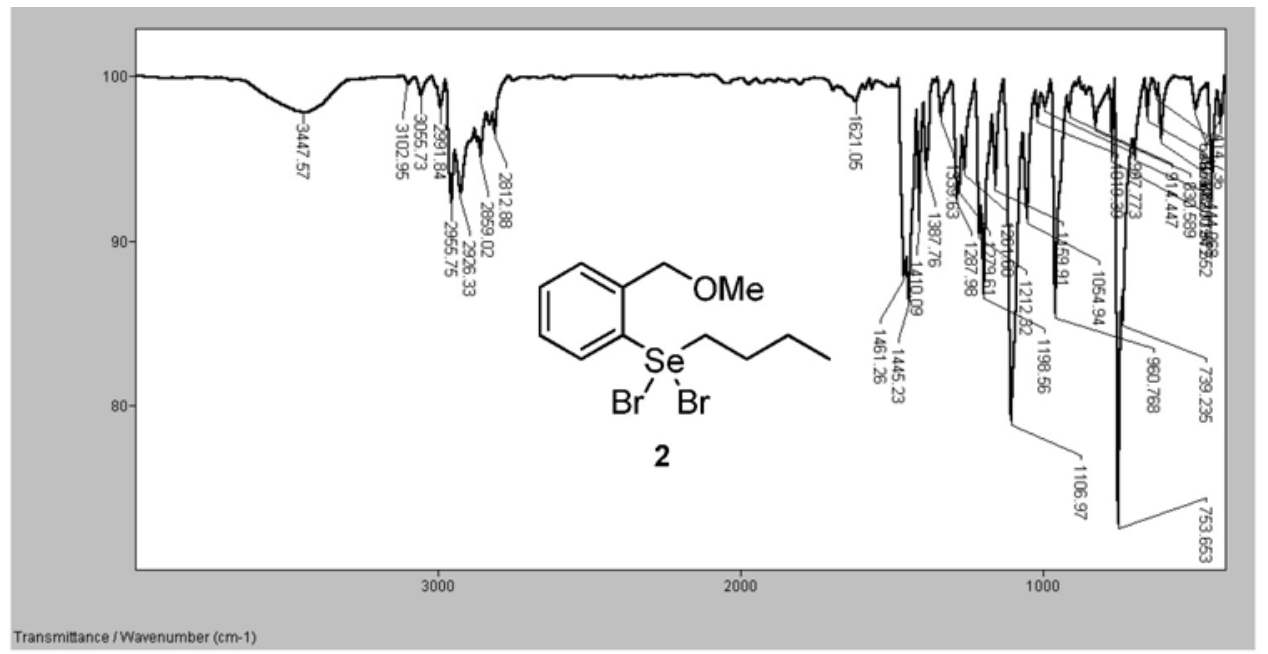

Figure S41. Infrared spectrum of selenane 2. 
Inhibition of cysteine cathepsins V and S by organoselenides 9, 11, 12 and 14
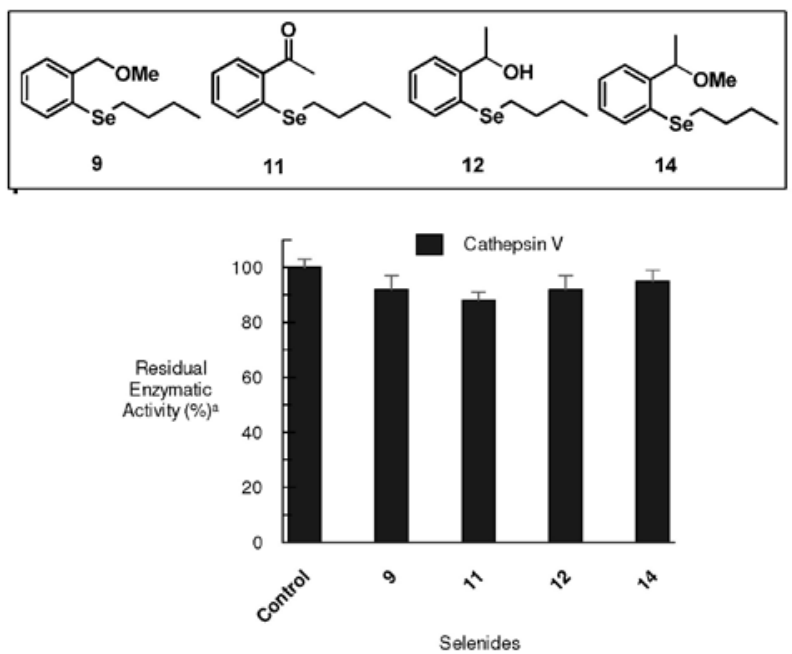

Figure S42. Inhibition profile for cathepsin V using selenides 9, 11, 12 and $14\left(1 \mu \mathrm{mol} \mathrm{L}^{-1}\right)$. Conditions: Cathepsin $\mathrm{V}$ in sodium acetate buffer (50 mmol..-1 ${ }^{-1}$ pH 5.5) containing EDTA $\left(2.5 \mathrm{mmol} \mathrm{L}^{-1}\right){ }^{\mathrm{a}}$ Average of three determinations.

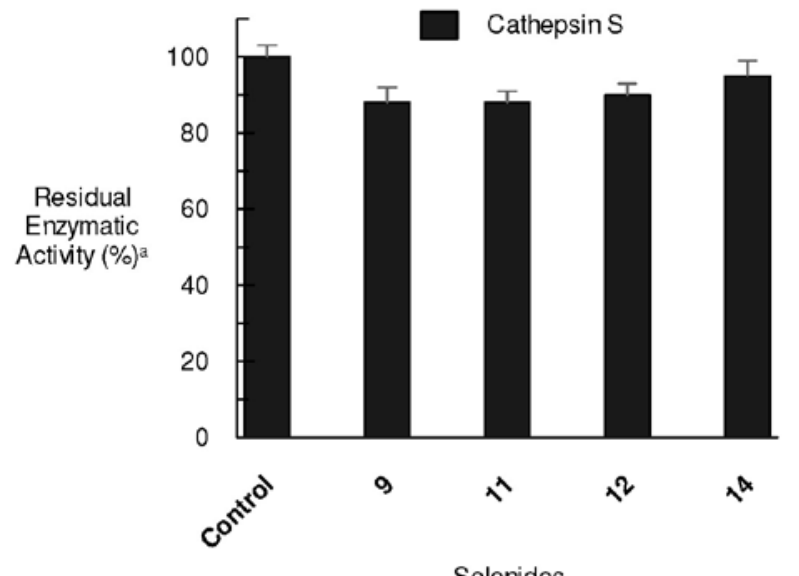

Figure S43. Inhibition profile for cathepsin $S$ using selenides 9, 11, 12 and $14\left(1 \mu \mathrm{mol} . \mathrm{L}^{-1}\right)$. Conditions: Cathepsin $\mathrm{V}$ in sodium phosphate buffer $\left(50 \mathrm{mmol} \mathrm{L}^{-1} ; \mathrm{pH} 6.5\right)$ containing EDTA $\left(2.5 \mathrm{mmol} \mathrm{L}^{-1}\right)$. ${ }^{\mathrm{a}}$ Average of three determinations.

\section{Enzyme kinetics for cathepsins}

Time course of the hydrolysis of fluorogenic substrate (Cbz-FR-AMC) in the presence and absence of organoselenanes in the indicated concentrations; relation of the observed first-order inactivation constants $\left(k_{\mathrm{obs}}\right)$ and the used organoselanes concentrations
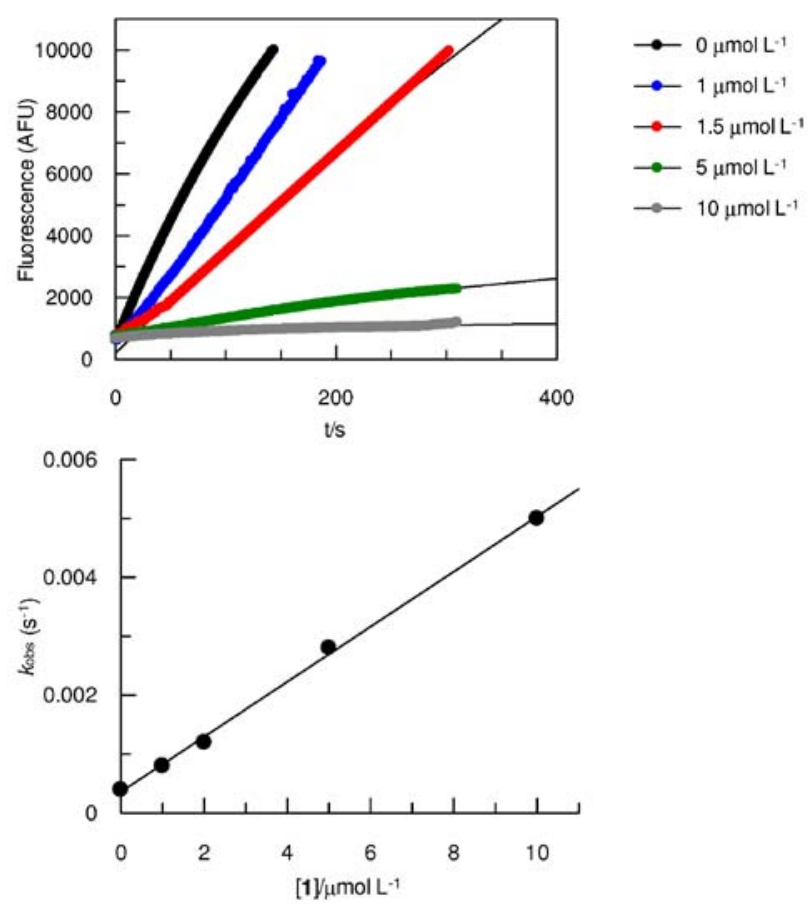

Figure S44. Enzyme kinetic for cathepsin V using selenane $\mathbf{1}$ as inhibitor.
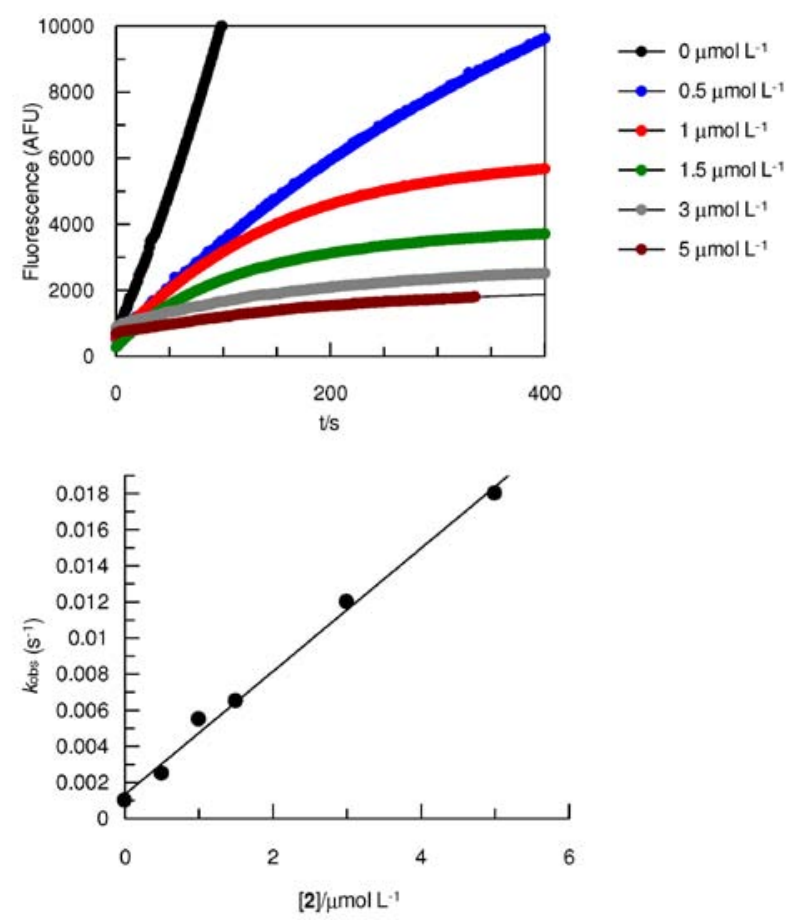

Figure S45. Enzyme kinetic for cathepsin V using selenane $\mathbf{2}$ as inhibitor. 


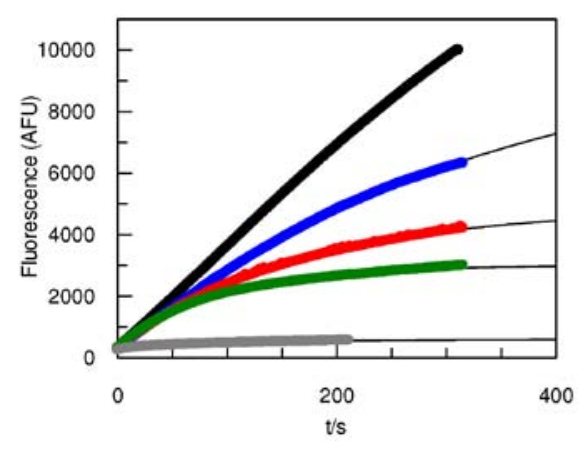

$$
\begin{aligned}
& \rightarrow 0 \mu \mathrm{mol} \mathrm{L}^{-1} \\
& \rightarrow-2 \mu \mathrm{mol} \mathrm{L}^{-1} \\
& \rightarrow-4 \mu \mathrm{mol} \mathrm{L}^{-1} \\
& \rightarrow 6 \mu \mathrm{mol} \mathrm{L}^{-1} \\
& \rightarrow 10 \mu \mathrm{mol} \mathrm{L}^{-1}
\end{aligned}
$$

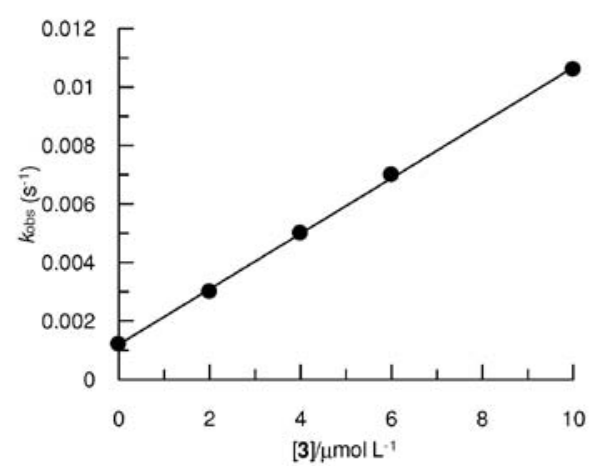

Figure S46. Enzyme kinetic for cathepsin V using selenane $\mathbf{3}$ as inhibitor.
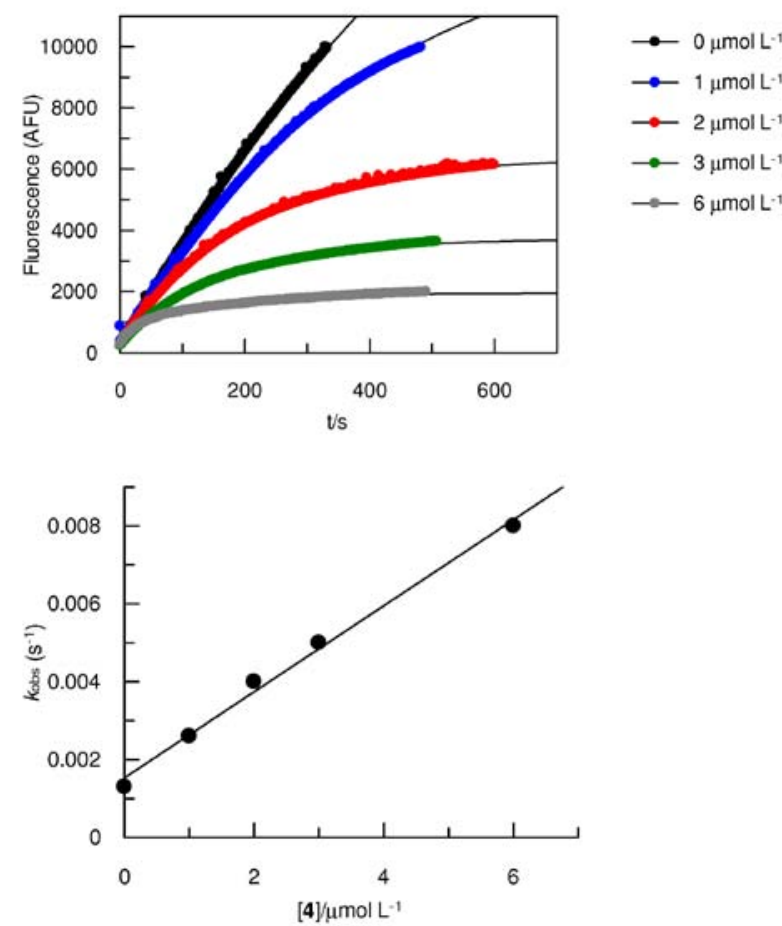

Figure S47. Enzyme kinetic for cathepsin V using selenane $\mathbf{4}$ as inhibitor.
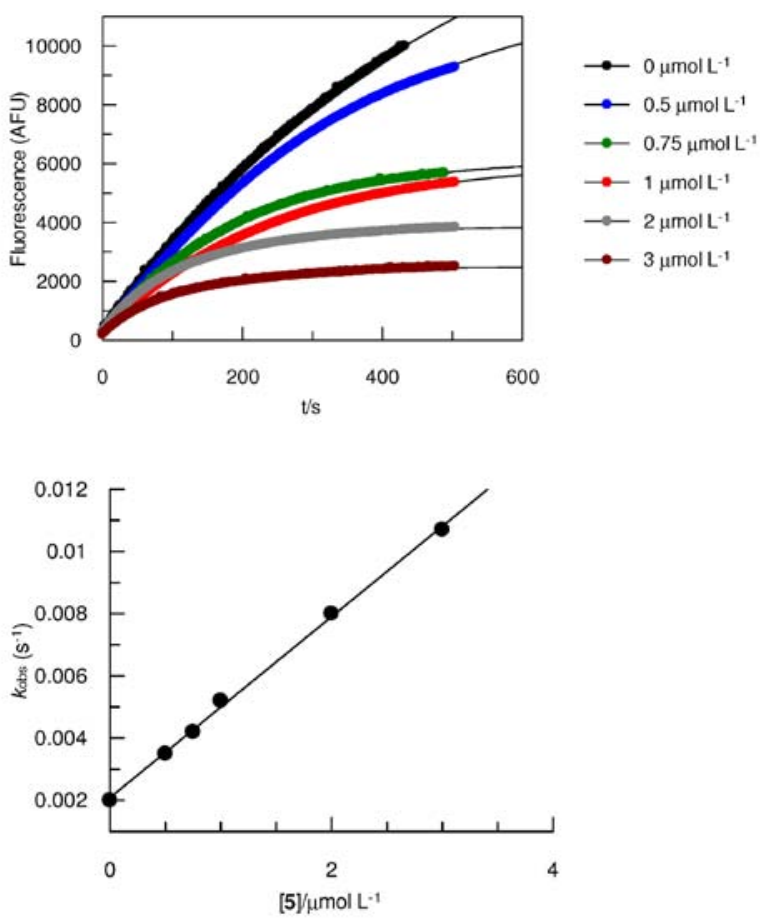

Figure S48. Enzyme kinetic for cathepsin V using selenane $\mathbf{5}$ as inhibitor.
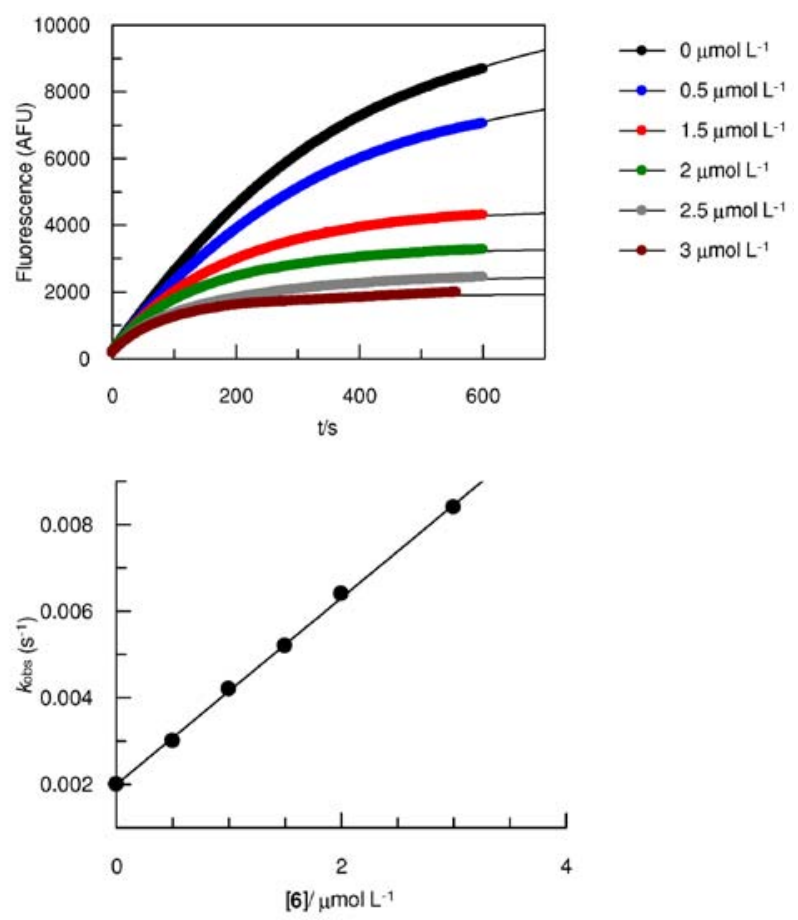

Figure S49. Enzyme kinetic for cathepsin V using selenane $\mathbf{6}$ as inhibitor. 


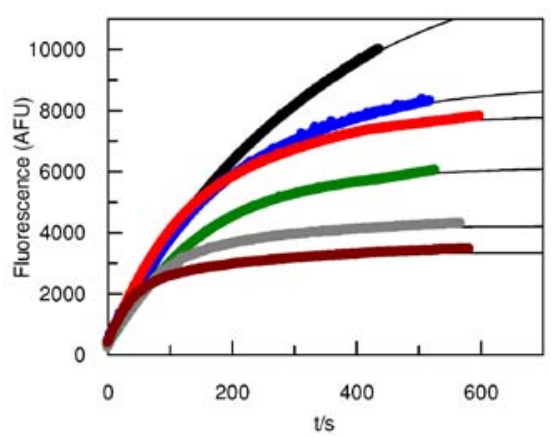

$$
\begin{aligned}
& \rightarrow-0 \mu \mathrm{mol} \mathrm{L}^{-1} \\
& \rightarrow-1 \mu \mathrm{mol} \mathrm{L}^{-1} \\
& \rightarrow-2 \mu \mathrm{mol} \mathrm{L}^{-1} \\
& \rightarrow-3 \mu \mathrm{mol} \mathrm{L}^{-1} \\
& \rightarrow-4 \mu \mathrm{mol} \mathrm{L}^{-1} \\
& \rightarrow 6 \mu \mathrm{mol} \mathrm{L}^{-1}
\end{aligned}
$$
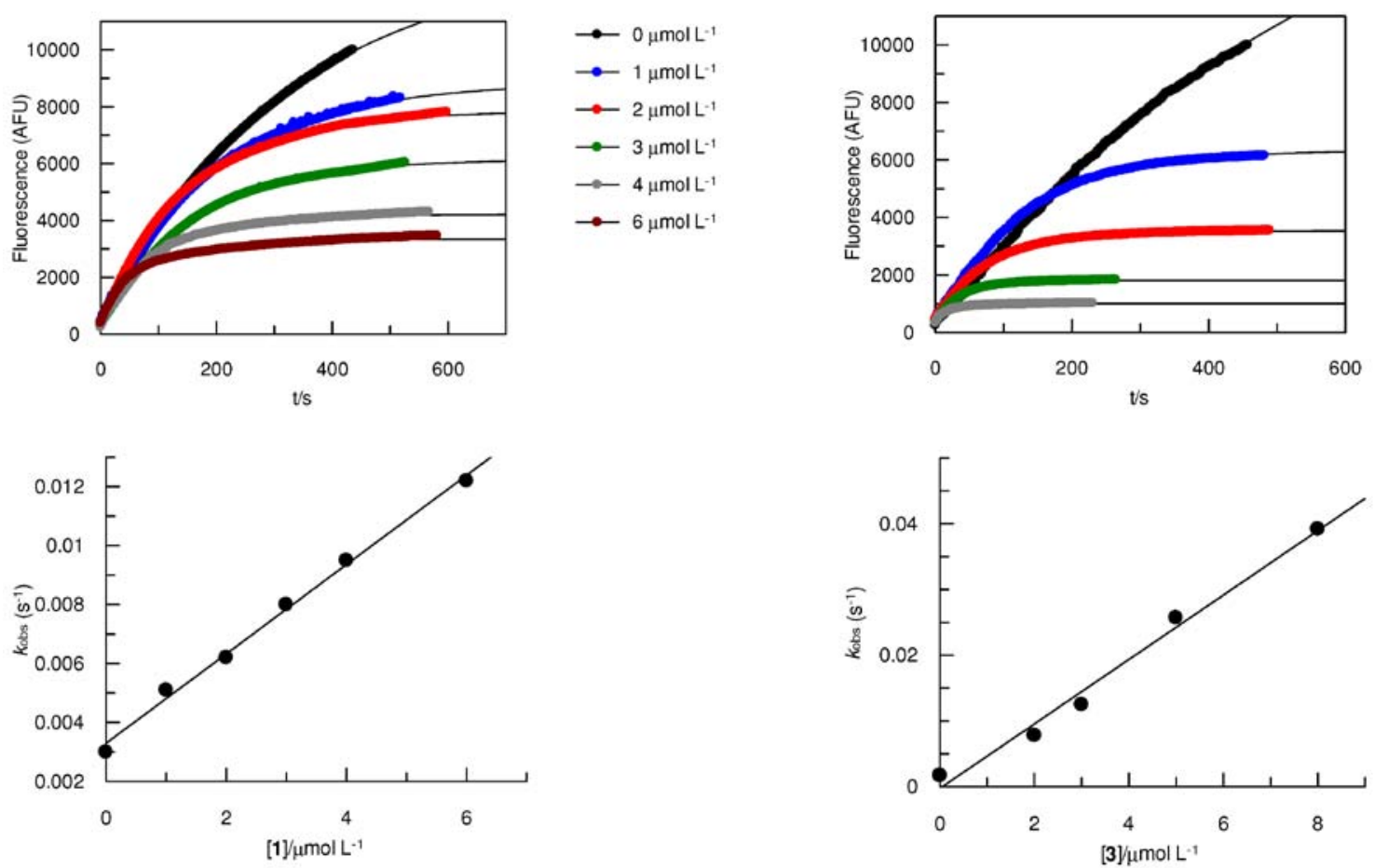

$$
\begin{aligned}
& \rightarrow 0 \mu \mathrm{mol} \mathrm{L}^{-1} \\
& \rightarrow 2 \mu \mathrm{mol} \mathrm{L}^{-1} \\
& \rightarrow-3 \mu \mathrm{mol} \mathrm{L}^{-1} \\
& \rightarrow-5 \mu \mathrm{mol} \mathrm{L}^{-1} \\
& \rightarrow-8 \mu \mathrm{mol} \mathrm{L}^{-1}
\end{aligned}
$$

Figure S50. Enzyme kinetic for cathepsin S using selenane $\mathbf{1}$ as inhibitor.

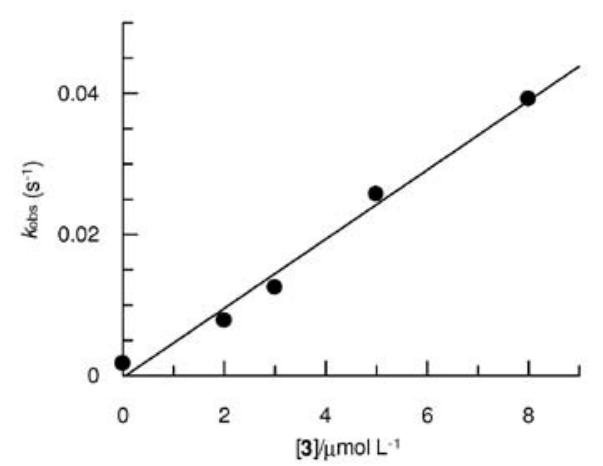

Figure S52. Enzyme kinetic for cathepsin S using selenane $\mathbf{3}$ as inhibitor.

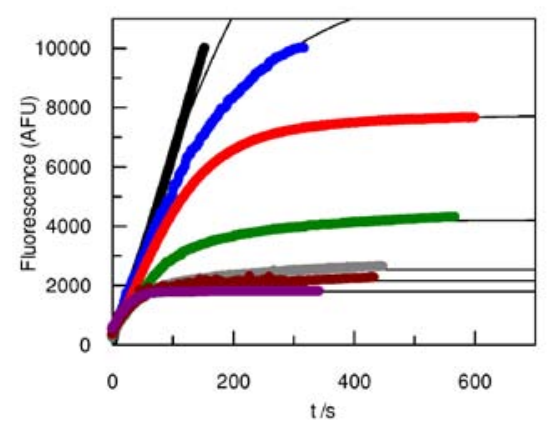

$$
\begin{aligned}
& \rightarrow 0 \mu \mathrm{mol} \mathrm{L}^{-1} \\
& \rightarrow-1 \mu \mathrm{mol} \mathrm{L}^{-1} \\
& \rightarrow-2 \mu \mathrm{mol} \mathrm{L}^{-1} \\
& \rightarrow-3 \mu \mathrm{mollL}^{-1} \\
& \rightarrow-4 \mu \mathrm{mol} \mathrm{L}^{-1} \\
& \rightarrow-5 \mu \mathrm{mol} \mathrm{L}^{-1} \\
& \rightarrow-10 \mu \mathrm{mol} \mathrm{L}^{-1}
\end{aligned}
$$
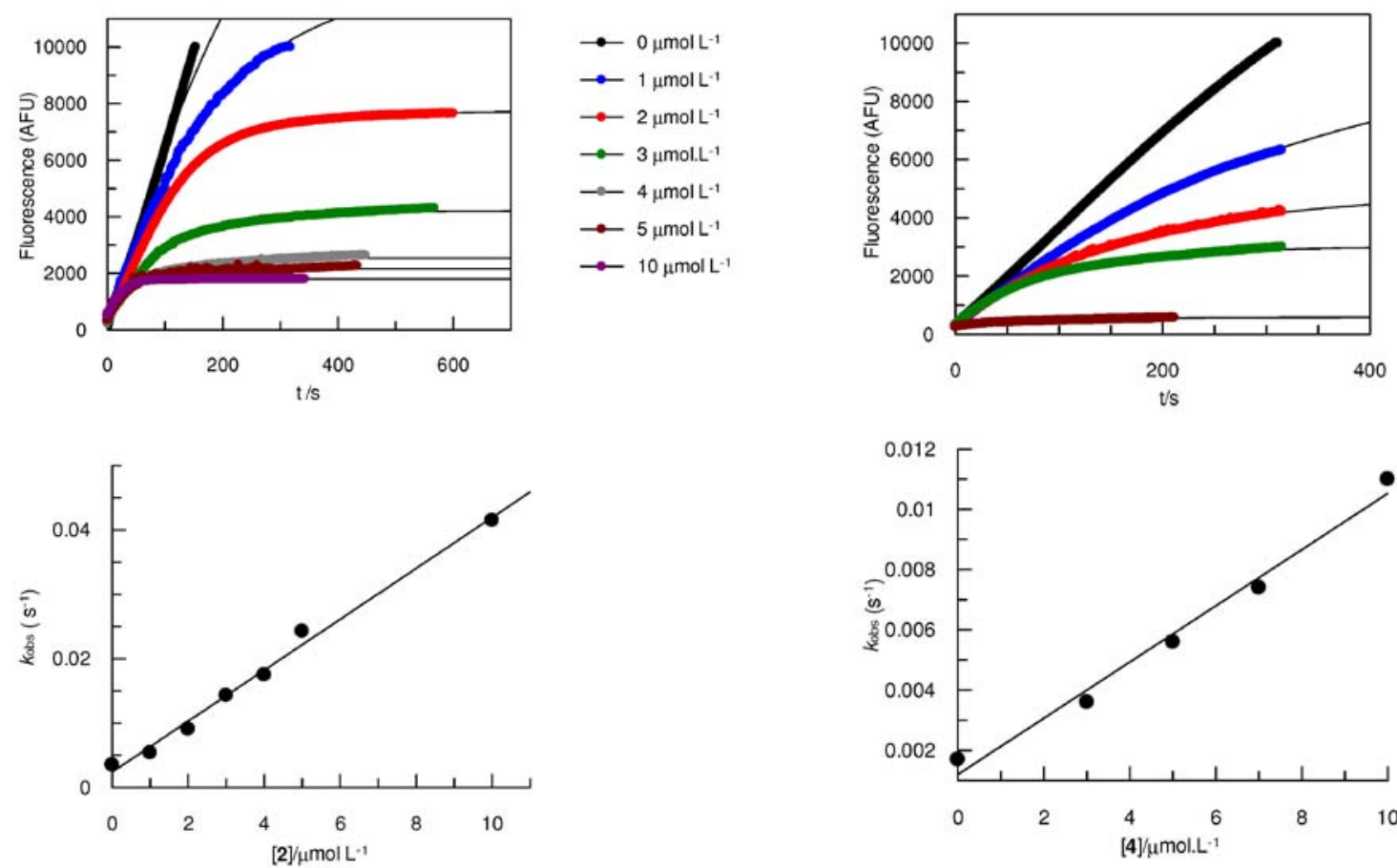

$$
\begin{aligned}
& \rightarrow 0 \mu \mathrm{mol} \mathrm{L}^{-1} \\
& \rightarrow-3 \mu \mathrm{mol} \mathrm{L}^{-1} \\
& \rightarrow-5 \mu \mathrm{mol} \mathrm{L}^{-1} \\
& \rightarrow-7 \mu \mathrm{mol} \mathrm{L}^{-1} \\
& \rightarrow-10 \mu \mathrm{mol} \mathrm{L}^{-1}
\end{aligned}
$$

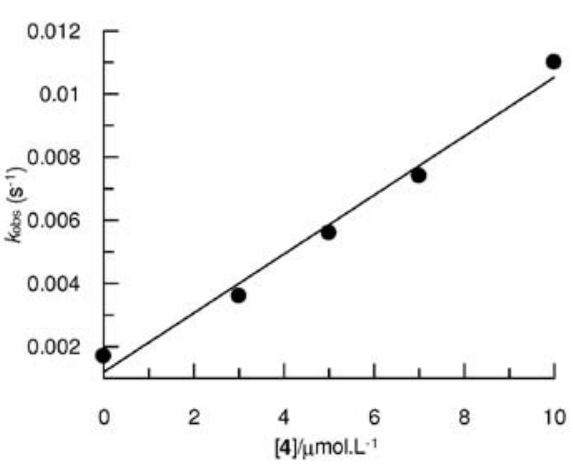

Figure S51. Enzyme kinetic for cathepsin S using selenane $\mathbf{2}$ as inhibitor.

Figure S53. Enzyme kinetic for cathepsin S using selenane $\mathbf{4}$ as inhibitor. 

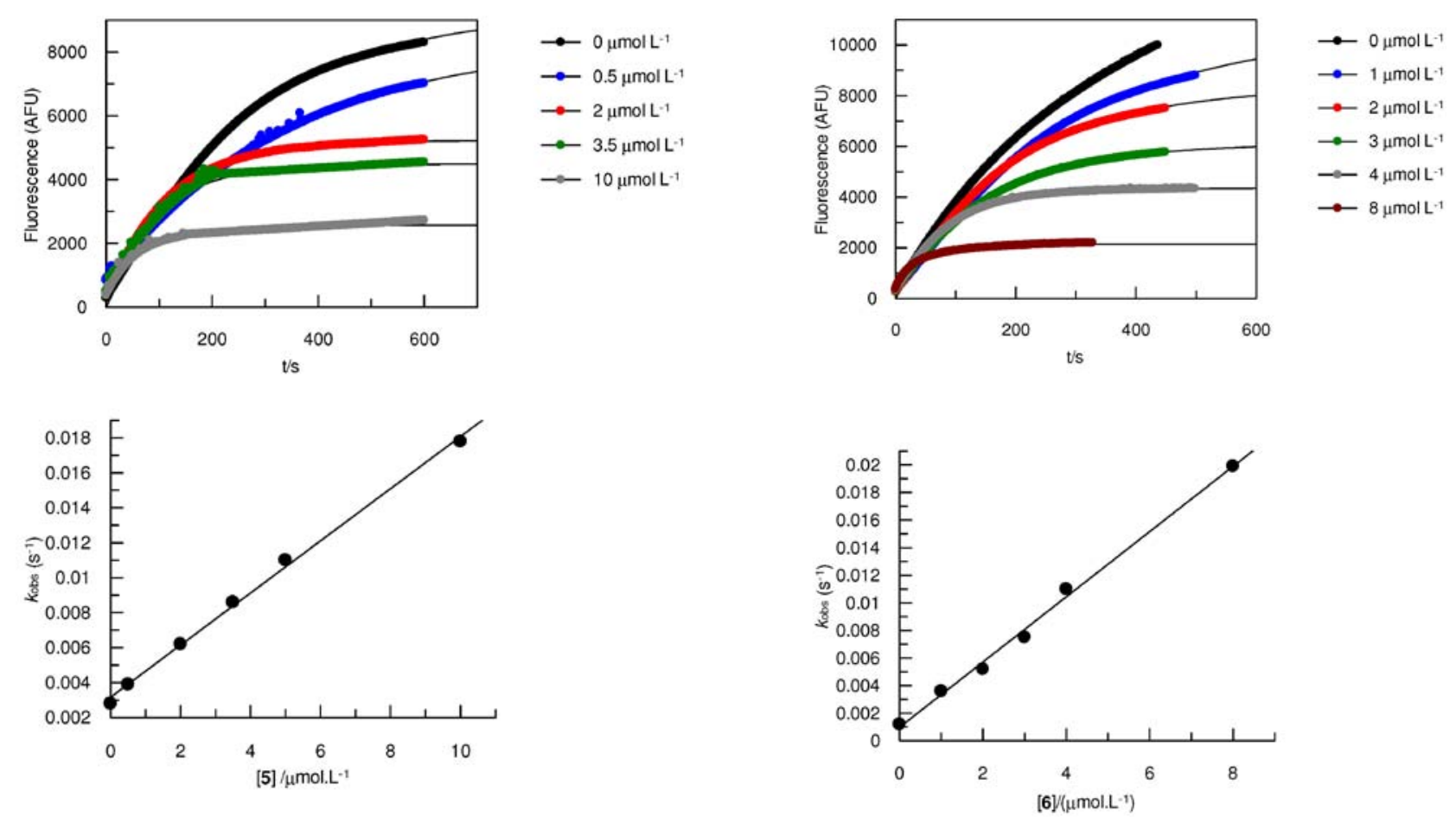

Figure S54. Enzyme kinetic for cathepsin S using selenane $\mathbf{5}$ as inhibitor.

Figure S55. Enzyme kinetic for cathepsin S using selenane $\mathbf{6}$ as inhibitor.

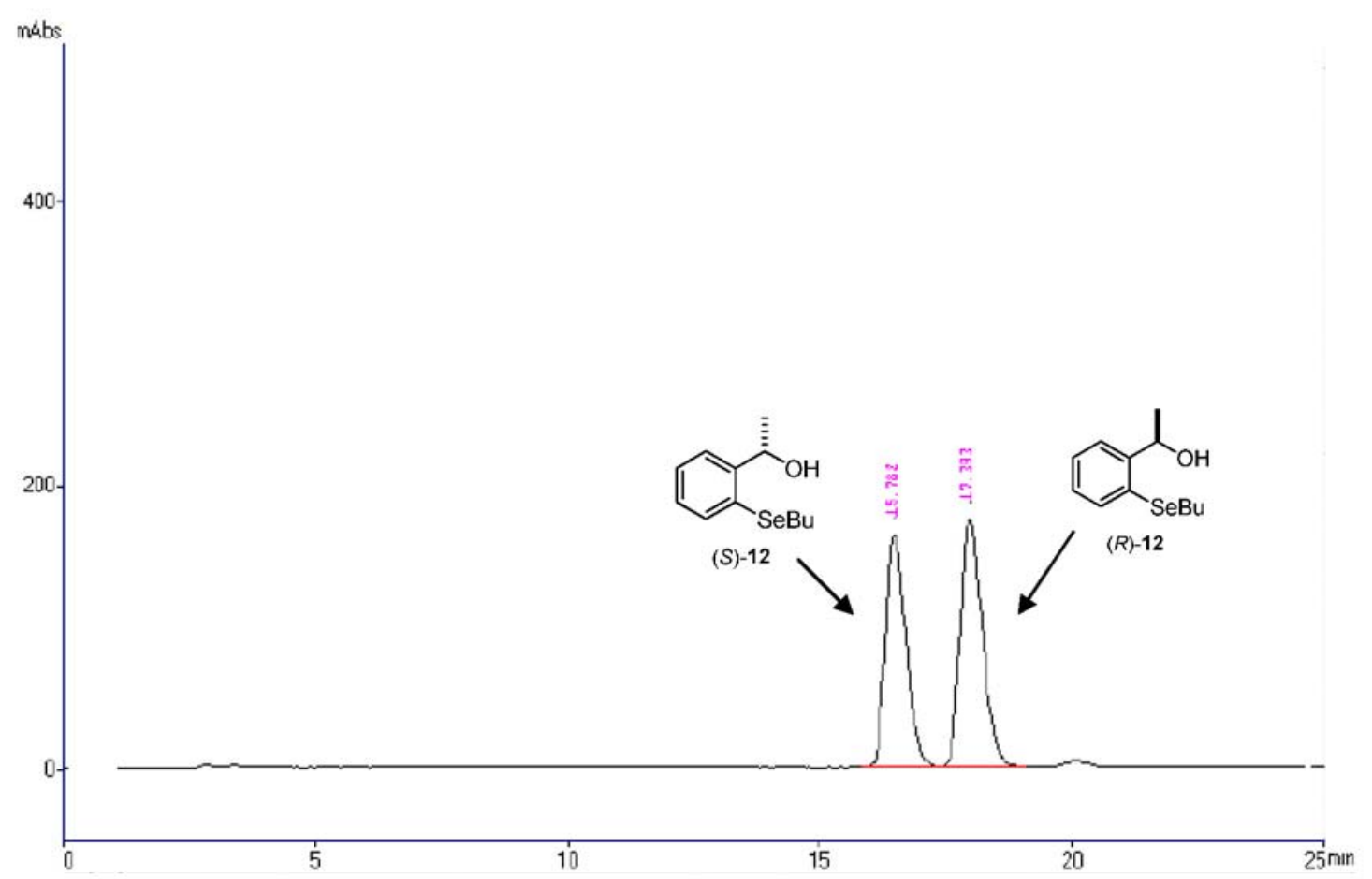

Figure S56. Enzymatic kinetic resolution of $(R S)-\mathbf{1 2}$. The enantioenriched compounds $(S)$-12 and $(R)-\mathbf{1 2}$ were prepared according to the method described in the text. 


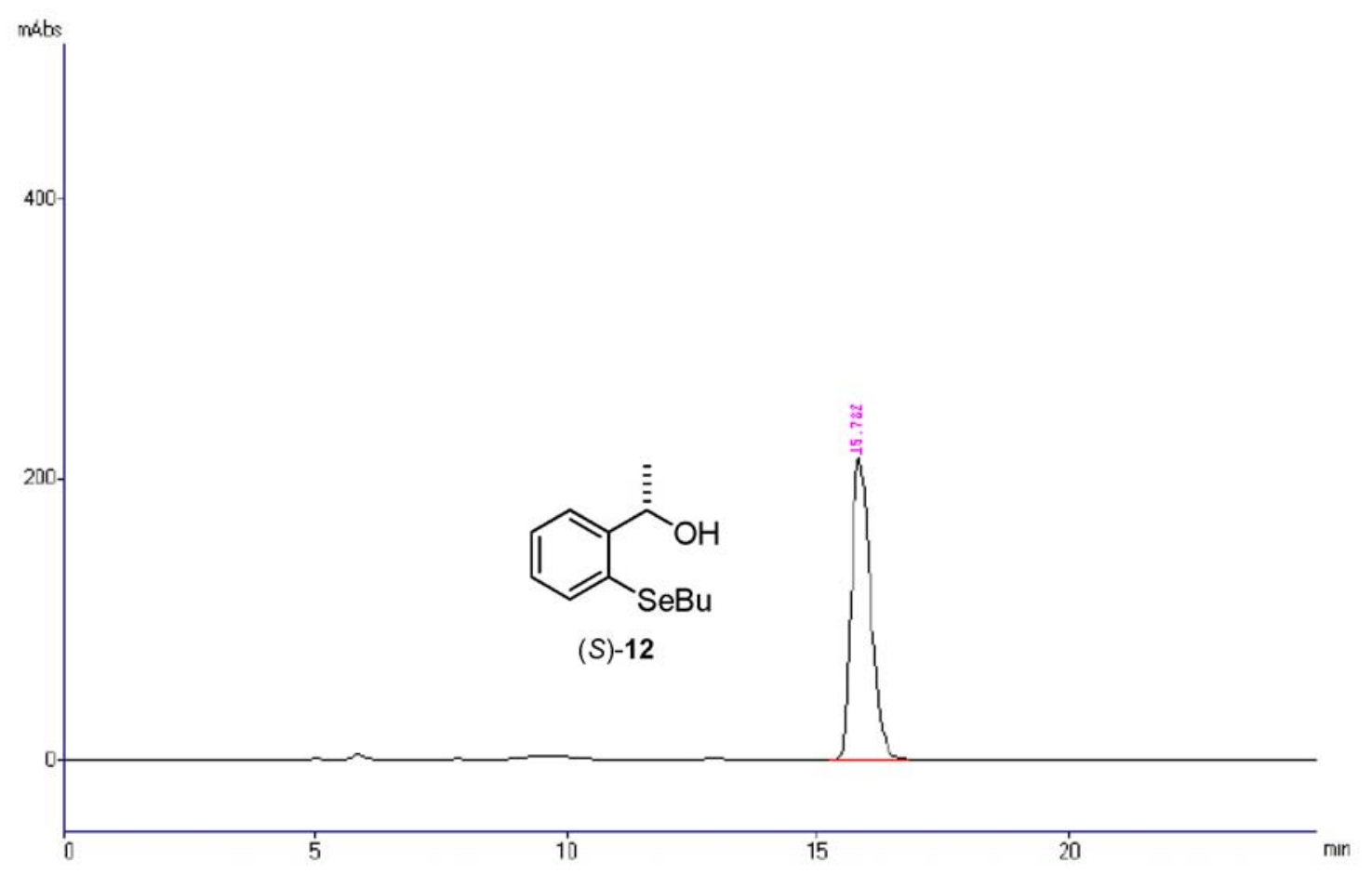

Figure S57. $(S)-1-\left(2-\left(\right.\right.$ butylselanyl)phenyl)ethanol (12): Isolated yield $=45 \%$; Enantiomeric excess $>99 \% ;[\alpha]_{D}^{22}=-23.9\left(c=0.78 ; \mathrm{CHCl}_{3}\right)$. HPLC condition: Chiralcel ${ }^{\circledR}$ OJ-H column, $n$-hexane/ $i$-PrOH (99:1), $1.0 \mathrm{~mL} \mathrm{~min}^{-1}, 254 \mathrm{~nm} \mathrm{UV}$ detector, $t_{\mathrm{R}}=15.8 \mathrm{~min}$.

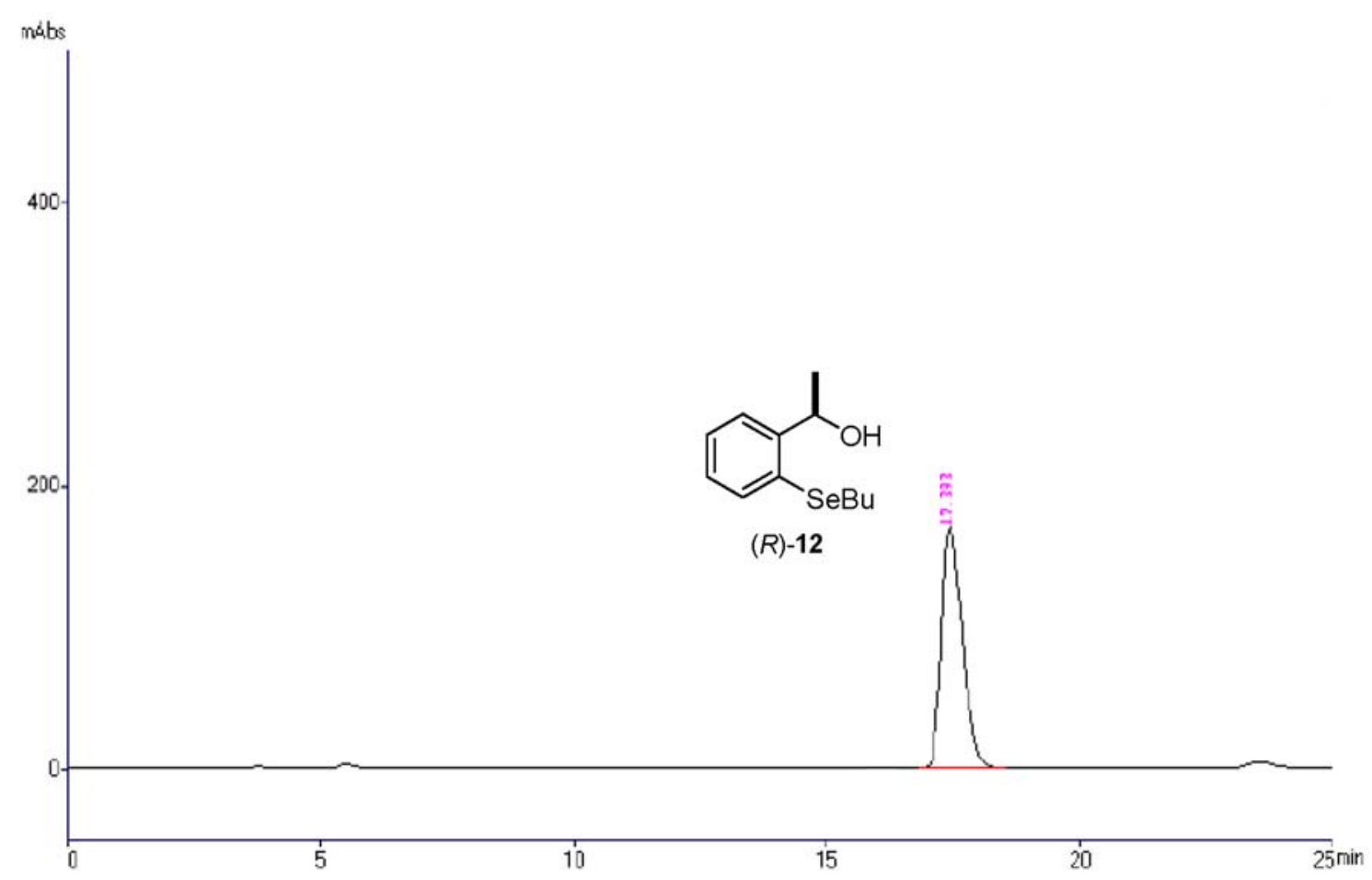

Figure S58. $(R)$-1-(2-(butylselanyl)phenyl)ethanol (12): Isolated yield $=45 \%$; Enantiomeric excess $>99 \% ;[\alpha]_{\mathrm{D}}^{22}=+24.1\left(c=0.80 ; \mathrm{CHCl}_{3}\right)$. $\mathrm{HPLC}^{2}$ condition: Chiralcel ${ }^{\circledR} \mathrm{OJ}-\mathrm{H}$ column, $n$-hexane/ $i$-PrOH (99:1), $1.0 \mathrm{~mL} \mathrm{~min}^{-1}, 254 \mathrm{~nm} \mathrm{UV}$ detector, $t_{\mathrm{R}}=17.3 \mathrm{~min}$. 